\title{
POLITICAL OPPOSITION IN UKRAINE AND ITS EFFECTIVENESS
}

By Viktoriya Thomson, BEd (Math), MPA.

\author{
A thesis submitted to \\ the Faculty of Graduate Studies and Research \\ in partial fulfillment of \\ the requirements for the degree of \\ Master of Arts
}

Department of Political Science

Carleton University

Ottawa, Ontario

Canada

Viktoriya Thomson 2008 


$\begin{array}{ll}\begin{array}{l}\text { Library and } \\ \text { Archives Canada }\end{array} & \begin{array}{l}\text { Bibliothèque et } \\ \text { Archives Canada }\end{array} \\ \begin{array}{l}\text { Published Heritage } \\ \text { Branch }\end{array} & \begin{array}{l}\text { Direction du } \\ \text { Patrimoine de l'édition }\end{array} \\ \begin{array}{l}\text { 395 Wellington Street } \\ \text { Ottawa ON K1A 0N4 } \\ \text { Canada }\end{array} & \begin{array}{l}\text { O95, rue Wellington } \\ \text { Ottawa ON K1A 0N4 } \\ \text { Canada }\end{array}\end{array}$

Your file Votre référence ISBN: 978-0-494-40614-4 Our file Notre référence ISBN: 978-0-494-40614-4

NOTICE:

The author has granted a nonexclusive license allowing Library and Archives Canada to reproduce, publish, archive, preserve, conserve, communicate to the public by telecommunication or on the Internet, loan, distribute and sell theses worldwide, for commercial or noncommercial purposes, in microform, paper, electronic and/or any other formats.

The author retains copyright ownership and moral rights in this thesis. Neither the thesis nor substantial extracts from it may be printed or otherwise reproduced without the author's permission.
AVIS:

L'auteur a accordé une licence non exclusive permettant à la Bibliothèque et Archives Canada de reproduire, publier, archiver, sauvegarder, conserver, transmettre au public par télécommunication ou par l'Internet, prêter, distribuer et vendre des thèses partout dans le monde, à des fins commerciales ou autres, sur support microforme, papier, électronique et/ou autres formats.

L'auteur conserve la propriété du droit d'auteur et des droits moraux qui protège cette thèse. $\mathrm{Ni}$ la thèse ni des extraits substantiels de celle-ci ne doivent être imprimés ou autrement reproduits sans son autorisation.
In compliance with the Canadian

Privacy Act some supporting forms may have been removed from this thesis.

While these forms may be included in the document page count, their removal does not represent any loss of content from the thesis.
Conformément à la loi canadienne sur la protection de la vie privée, quelques formulaires secondaires ont été enlevés de cette thèse.

Bien que ces formulaires aient inclus dans la pagination, il n'y aura aucun contenu manquant.

\section{Canada}




\begin{abstract}
This thesis analyzes the effectiveness of the political opposition in Ukraine. This study reviews the parties that comprised the "Orange team" and their failure to create a coalition government after the presidential election "Orange revolution" in 2004 and the 2006 parliamentary election.

An effective political opposition is defined as a political opposition that has an alternative program to that of the government, and the personnel to govern. To be effective the parties of the opposition should be cohesive, united and cooperative.

This thesis argues that despite their electoral success during the Orange revolution the parties of the Orange team were not effective as the opposition as defined in theoretical terms. The institutional and civic framework of Ukraine, which consists of the constitution, the electoral system, the political party system and the mass political culture prevent the development of the effective political opposition in Ukraine. For that reason the parties' failure to create a coalition government was the result of their ineffectiveness as political opposition.
\end{abstract}




\section{Acknowledgement}

I would like to thank my family for all the support and patience that they gave me during my study and in the process of working on this thesis.

I am very grateful to my supervisor, Professor Joan DeBardeleben, for her help, encouragement and advice throughout my time at Carleton and especially during the period of my thesis. I admire her dedication to and knowledge of post-Soviet countries and their emerging civil society.

This thesis is dedicated to Nicholas, who gives me strength and happiness every day. 


\section{Table of Contents}

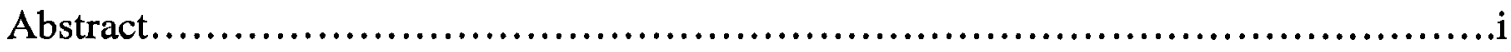

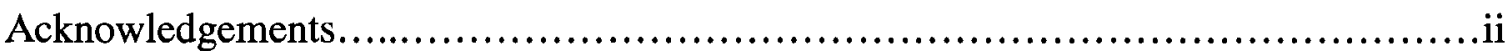

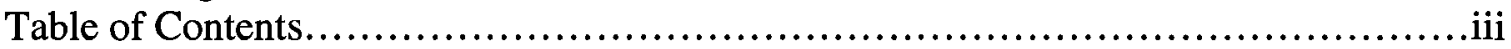

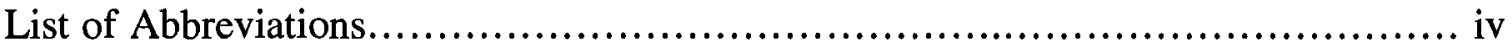

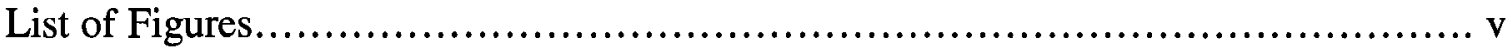

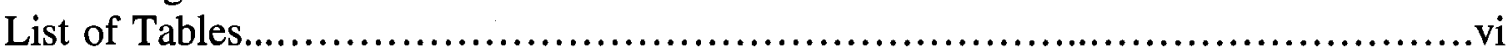

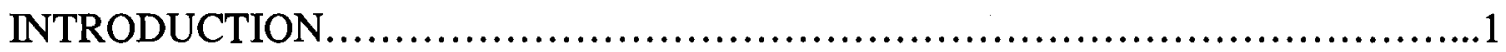

Chapter 1 . Theory on the study of the political opposition and its effectiveness................................................................. 10

1.1. Background of the study of the political opposition ........................13

1.2. Robert Dahl on the political opposition in Western Democracies............ 14 1.3. Ludger Helms on the institutionalized political opposition in modern parliamentary democracies.....................................................19 1.4. Leonard Shapiro and Gordon Skilling on the political opposition in one-party

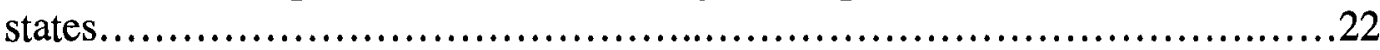

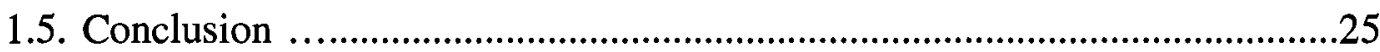

Chapter 2. Political party system in Ukraine and the effectiveness of the political opposition.................................................................26

2.1. Overview of the multiparty political system..................................30

2.2. Origin of the parties of the Orange team..................................36

2.2.1. The Socialist Party of Ukraine ....................................36

2.2.2. The bloc Yulia Tymoshenko.....................................38

2.2.3. The bloc Our Ukraine..............................................40

2.3. Social base of the parties of the Orange team....................... 43

2.4. Party competition.................................................... 45

2.4.1. 2002 parliamentary election...................................45

2.4.2. 2006 parliamentary election..................................49

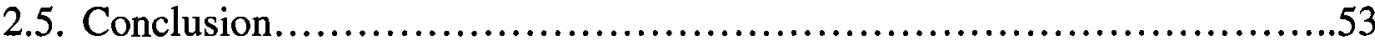

Chapter 3. Constitution of Ukraine and the effectiveness of the political

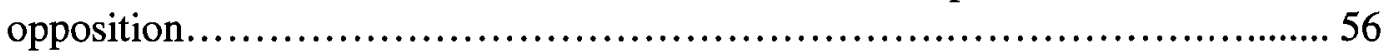

3.1. Overview of the Constitution of Ukraine .................................58

3.2. Constitution during the 2002 parliamentary election.......................61

3.2.1. The power of the parliament....................................61

3.2.2. The power of the president....................................65

3.2.3. The system of appointing and removing the government...........66

3.3. Constitution during the 2004 presidential election.........................68

3.4. Constitution during the 2006 parliamentary election...................... 70 
3.4.1. The power of the parliament................................... 70

3.4.2. The role of the president........................................76

3.4.3. The system of appointing and removing the government............78

3.5. Conclusion .......................................................... 80

Chapter 4. The electoral system in Ukraine and the effectiveness of the political

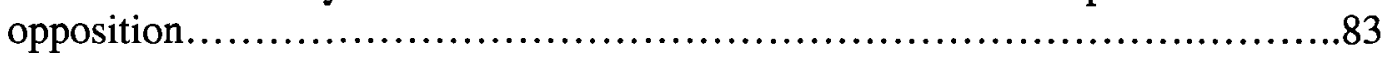

4.1. Overview of the electoral systems in Ukraine ............................88

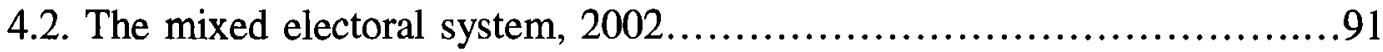

4.2.1. The system of candidate nomination.............................91

4.2.2. The electoral formula.........................................97

4.2.3. The coefficient of disproportionality of the electoral formula.......97

4.3. The proportional representation electoral system, $2006 \ldots \ldots \ldots \ldots \ldots \ldots \ldots . . .104$

4.3.1. The system of candidate nomination.............................104

4.3.2. The electoral formula.......................................107

4.3.3. The coefficient of disproportionality of the electoral formula......107

4.4. Conclusion. 109

Chapter 5. Political culture and the effectiveness of the political opposition in

Ukraine ................................................................ 112

5.1. Political culture and the effectiveness of the political opposition...........116

5.2. Overview of the political culture in Ukraine ................................118

5.3. The orientation towards governmental structures.......................121

5.3.1. Regime orientation.......................................... 121

5.3.2. Orientation towards governmental institutions..................122

5.4. The orientation towards others in the political system....................128

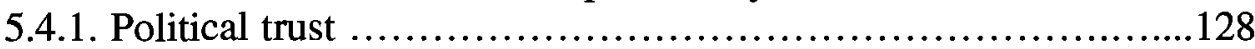

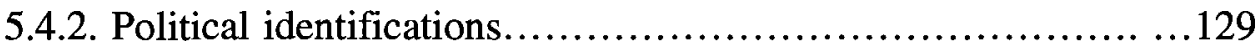

5.5. The orientation towards own political activity.......................132

5.5.1. Political awareness..........................................132

5.5.2. Political efficacy......................................... 133

5.6. Age and Education as predictors of the political culture....................135

5.7. Mass political culture and the political elite.............................138

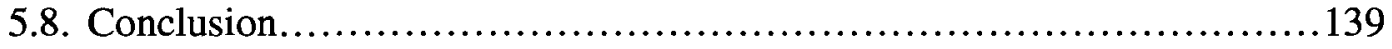

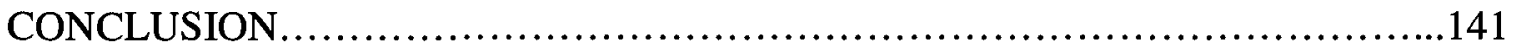

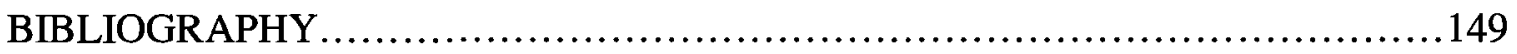




\section{List of Abbreviations}

$\begin{array}{ll}\text { CECU } & \text { Central Electoral Commission of Ukraine } \\ \text { BYT } & \text { BlocYulia Tymoshenko } \\ \text { NATO } & \text { North Atlantic Treaty Organization } \\ \text { OSCE } & \text { Organization for Security and Co-operation in Europe } \\ \text { Our Ukraine } & \text { Bloc Viktor Yushchenko Our Ukraine } \\ \text { Rada } & \text { Verkhovna Rada of Ukraine } \\ \text { PR } & \text { Proportional representation } \\ \text { SMD } & \text { Single member electoral district } \\ \text { UP } & \text { University Press } \\ \text { VVR } & \text { Vidomosty Verkhovnoyi Rady Ukrainy } \\ \text { WTO } & \text { World Trade Organization }\end{array}$




\section{List of Figures}

2.1 Number of Political Parties in the Elections, 1998-2006...........................32

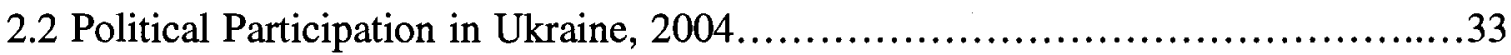

2.3 Level of Trust in Political Parties, 1994-2004....................................34

3.1 Parliamentary Factions in the Rada, IV convocation...............................64

4.1 Party Affiliation of the Candidates, 2002 Parliamentary Election...................94

4.2 Party Affiliation of the Candidates, 2006 Parliamentary Election.................106

5.1 Belief in the Strong Leadership among Age Groups, 2004......................122

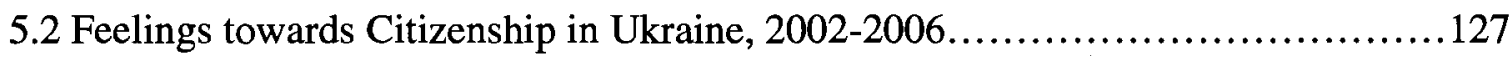

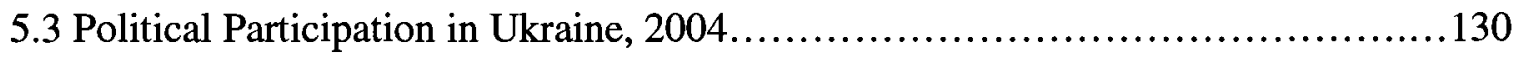

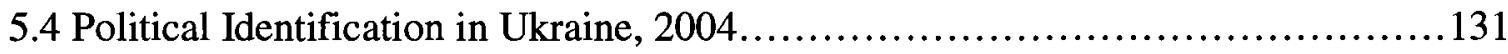

5.5 Level of Political Knowledge in Ukraine, 2002-2006..........................133

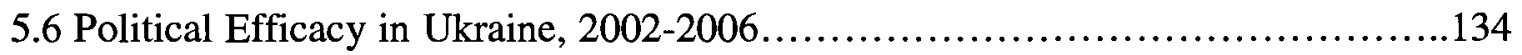

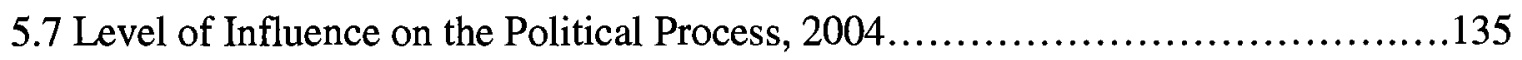




\section{List of Tables}

2.1 Political Parties of the Orange team..............................................43

3.1 Results of the 2002 Parliamentary Election.....................................62

3.2 Prime-Ministers of Ukraine, Presidential Candidates.............................68

4.1 Electoral Systems in Ukraine, 1994-2006..................................90

4.2 Number of Candidates, SMD, by Regions of Ukraine, 2002 Parliamentary

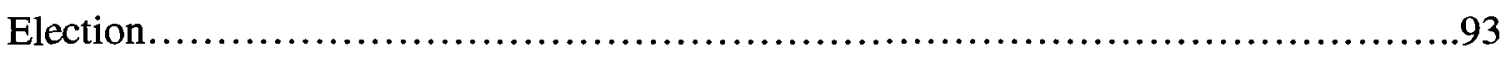

4.3 Threshold of Inclusion, SMD, 2002 Parliamentary Election ......................95

4.4 Deviation of Proportionality, SMD, 2002 Parliamentary Election..................99

4.5 Results of the 2002 Parliamentary Election....................................101

4.6 Deviation of Proportionality, PR list, 2002 Parliamentary Election.................102

4.7 Deviation of Proportionality, PR list, 2006 Parliamentary Election.................108

5.1 Level of Political Trust in Ukraine, 2002-2006...............................125

5.2 Level of Interpersonal Trust in Ukraine, 2002-2006..............................129

5.3 Political Trust, Political Activity according to Age and Education, 2004...........136 


\section{INTRODUCTION}

In the fall of 2004 the world's attention was fixed upon the orange clad protestors who occupied the historic Maydan square in Kyiv, Ukraine. The well organized, sympathetic citizens spoke eloquently, individually and collectively, against the barely concealed electoral fraud that saw a pro-Russian, government supported candidate, Viktor Yanukovich, declared President. ${ }^{1}$ In the ensuing days and weeks, the protest spread and organs of state, including the Ministry of Internal Affairs, the Central Electoral Commission of Ukraine (CECU) and the regional court of Kiev, belatedly responded to the growing protests and this led to the cancellation of the election results. However, it was the opposition, led by former prime-minister Viktor Yushchenko and Yulia Tymoshenko, who united the majority of citizens and disparate political parties to take concerted action against the initial results. It was generally portrayed in the Western press as an awakening of democracy; the unified opposition, peacefully working through the nation's proper institutions, overturned a fraudulent election and then won a fair one. ${ }^{2}$ Furthermore, the Ukrainian parliament, the Rada, which contained a majority of representatives from pro-government parties, appeared as a model of plural voices and checks and balances.

Although the opposition achieved success by winning the 2004 presidential election and creating a new government, it was not able to create a consolidated effective

\footnotetext{
${ }^{1}$ On the subject of the 2004 presidential election in Ukraine and the "Orange revolution" see Anders Åslund and Michael McFaul, eds., Revolution in Orange: the Origins of Ukraine's Democratic Breakthrough (Baltimore: Carnegie Endowment for International Peace, 2006); Andrew Wilson, Ukraine's Orange Revolution (London: Yale UP, 2005).

2 "Ukraine's clear choice," editorial, The Globe and Mail 30 Oct. 2004: A20, Joe Paraskevas, "Witness "birth of new Ukraine," National Post 22 Dec. 2004, natl. ed., A12.
} 
government. Once in power the "revolution" team did not succeed in creating a united stable government; within the year Prime-Minister Yulia Tymoshenko was dismissed from her post by her former ally President Viktor Yushchenko.

The 2006 parliamentary election only intensified the pre-existing divisions within the former Ukrainian opposition. The Orange team ${ }^{3}$ failed to create a government coalition in parliament even at the cost of losing the government to the pro-Yanukovich Party of Regions. Even after Yanukovich's party united with Socialist and Communist parties into a parliamentary coalition, the rest of the Orange team did not define themselves as the political opposition within the Rada. This raised a question about the definition and the role that political opposition plays in the political process in Ukraine; what is an opposition? Moreover, what is an effective opposition? This research on the Ukrainian political opposition is important because it is necessary to understand and explain the circumstances that led to the collapse of the Orange team once in power. Furthermore, the recent constitutional and electoral changes ${ }^{4}$ passed in Ukraine have increased the role of political parties and of the government, decreasing the role of the president. As a result, the relations between political factions in the Rada also changed. The new law on parliamentary rules provides a definition of parliamentary coalition; however it is silent on political opposition and its role. ${ }^{5}$ Significantly, numerous attempts were made by private members of the Rada to introduce bills to

\footnotetext{
${ }^{3}$ The Orange team refers to parties of the opposition during the Orange revolutions such as electoral bloc Viktor Yushchenko Our Ukraine, electoral bloc Yulia Tymoshenko (BYT) and the Socialist Party of Ukraine.

${ }^{4}$ The new Law on the Elections of the People's Deputy was introduced in July 2005 and replaced the preexisting mixed electoral system by proportional representation (PR) electoral system. Thus the 2006 parliamentary election was the first national election in accordance with a fully PR electoral system. ${ }_{5}$ Zakon Ukrainy pro reglament Verkhovnoyi Rady Ukrainy (Law of Ukraine on the rules and Procedures of Verkhovna Rada of Ukraine) no 3547-V, dated 16 March 2006, 15 August 2006 <http://zakon1.rada.gov.ua/cgi-bin/laws/main.cgi?nreg>.
} 
legislate the political opposition and its role, thereby institutionalizing it; however these attempts have been unsuccessful. ${ }^{6}$ The evolution of institutionalized political activity in Ukraine concentrates power in the hands of the parliamentary government, at the expense of presidential power without any increased support for the opposition within the Rada.

For the current research project the author argues that the existence of a parliamentary coalition that has the power to create the government can not be considered democratically legitimate without an effective political opposition. A political opposition that has influence, by offering thoughtful criticism and providing alternative programs and policies to the government, can strengthen the process of the democratic consolidation in Ukraine. This can improve the chances of Ukraine for integration into western political structures, specifically the European Union and NATO, which were declared to be key objectives by President Viktor Yushchenko in his inaugural speech upon his 2004 election victory. ${ }^{7}$ The importance of the role of the opposition, and its future development will therefore impact Ukraine's future strategic economic and security choices.

The existence of the political opposition in society is the defining characteristic of a democracy. All well established democracies share this common characteristic; the presence of an opposition that holds alternative views to the policies of the current government. Political theorist Robert Dahl wrote that "today one is inclined to regard the existence of an opposition party as very nearly the most distinctive characteristic of

\footnotetext{
${ }^{6}$ According to study by Ukrainian Centre for Independent Political Research, the bill on the political opposition was introduced 13 times during period of 1998-2006 by different deputies. See Svetlana G. Linonchuk, O.A.Yarosh, Parlamentsyka Opozytsiya v Ukraini: model ta provadzhennya (Kyiv: UCIPR, 2006), 4 September $2006<$ http://www.ucipr.kiev.ua/>.

${ }^{7}$ Inaugural address of the President of Ukraine Viktor Yushchenko to the Ukrainian people on Independence Square, Official site Viktor Yushchenko, 5 September 2006 $<$ http://www.yuschenko.com.ua/eng/Press_centre/168/2167>.
} 
democracy itself." ${ }^{, 8}$ The process of defining some political regimes as democratic and others as non-democratic often is based on the presence or absence of the political opposition. It is the central element of liberal democracy. For example, Duverger argued that "The existence of an organized opposition is an essential feature of 'Western' democracy, its absence a feature of 'Eastern' democracy." political opposition guarantees the accountability of the government and helps ensure its democratic nature. In established democracies the parliamentary political oppositions have equivalent legitimacy to their government and they provide a program of alternative policies to those of the incumbent government. A strong political opposition is evidence of the political representation of different groups within democratic societies.

The presence of an effective political opposition ${ }^{10}$ in transition countries ${ }^{11}$ can accelerate the process of democratization. The recent wave of the "colour revolutions"12 in a number of newly independent states raises questions about the role of political oppositions during these revolutions and of these oppositions' failures or successes in creating alternative governments after successful elections.

\footnotetext{
${ }^{8}$ Robert A. Dahl, ed., preface, Political Opposition in Western Democracies (New Haven: Yale UP, 1966).

${ }^{9}$ Maurice Duverger, Political Parties: Their Organizations and Activity in the Modern State (London: Methuen \& Co Ltd., 1978) 413.

${ }^{10}$ Effective political opposition refers to the political oppositions that have influence on government policy and provide an alternative program with the ability to introduce this program in the case of victory in the elections. This will be discussed in chapter one.

${ }^{11}$ Transition countries are defined as countries that are post-communist regimes and have attempted to introduce some, but not all, characteristics of consolidated democracy such as elected legislature and executive, free market, free media and rule of law. For more on the democratic transition and its phases see Juan J Linz, Alfred Stepan, Problems of Democratic transition and Consolidation. Southern Europe, South America, and Post-Communist Europe (Baltimore: The John Hopkins UP, Baltimore, 1996).

${ }^{12}$ The term "Color revolutions" refers to the revolutions in the post-soviet republics of Georgia, Ukraine and Kyrgyzstan that happened due to the fraud presidential and parliamentary elections. For more on the 'Color revolutions' and analysis of their success see Paul D'Anieri, "Explaining the success and failure of post-communist revolutions," Communist and Post-Communist Studies 39 (2006): 331-350. Henry E.Hale, "Democracy or autocracy on the march? The colored revolution as normal dynamics of patronal presidentialism," Communist and Post-Communist Studies 39 (2006): 305-329.
} 
The majority of academic works (Dahl, 1966; Duverger, 1978; Ionescu and Madariaga, 1968; Kolinsky, 1987; Helms, 2004) on the theory of political opposition are concerned with the study of the political opposition in Western parliamentary democracies or with opposition movements in one-party states (Schapiro, 1972; Skilling, 1971). The former, for the most part are concerned with the analysis of political party systems and with party competition during the elections. ${ }^{13}$ The latter refers to the dissident groups in the totalitarian regimes.

While the substance of these works is relevant to Ukraine, some of their assumptions, for example Dahl's contention that a multi-party system in combination with proportional representation electoral system ${ }^{14}$ leads to a cooperative opposition, do not always apply to Ukraine's circumstances.

This paper contends that even the works and studies of the opposition in postcommunist states of Eastern Europe ${ }^{15}$ cannot be generalised and applied to Ukraine. The countries of Eastern Europe experienced shorter periods of the communist regime and had a stronger base for the development of civil society, ${ }^{16}$ which helped in creating their respective political oppositions.

The current research project will attempt to contribute to the theory of political opposition in post-communist countries generally and in Ukraine particularly. It will

\footnotetext{
${ }^{13}$ Smith was trying to introduce the idea of the non-party type of the political opposition. See Gordon Smith, "Party and protest: two faces of opposition in Western Europe," ed. Eva Kolinsky, Opposition in Western Europe (Bechenham: Croom Helm Ltd., 1987) 52-76.

${ }^{14}$ Dahl 338.

${ }^{15}$ For the tasks of the opposition in post-communist countries the valuable works are by Alfred Stepan, "Democratic Opposition and Democratization Theory," Government and Opposition 32.4 (1997): 657-675, Pollack Detlef, Jan Wielgohs, ed., Dissent and Opposition in Communist Eastern Europe : origins of civil society and democratic transition (Burlington: Ashgate, 2004), Crzegorz Ekiert, "Democratization Process in East Central Europe: a theoretical reconsideration," British Journal of Political Science 21.3 (1991): 285313.

${ }^{16}$ The civil society is defined as the organizations, groups of citizens that united by the same interests (social, economical, cultural, and political) outside the state but operate with respect to the state institutions and the rule of law. This will be further discussed in chapter five.
} 
attempt to find practical recommendations for creating an effective political opposition in Ukraine

This project attempts to answer the question: why did the parties of the political opposition, the parties of Orange team, fail to create an effective alternative government after the Orange revolution and the 2006 parliamentary election?

The main objective of this project is to demonstrate that while the Ukrainian political opposition was successful in defeating the government in the 2004 presidential election, it was not an effective opposition in classical terms, because it failed to provide an alternative program and personnel to govern. This failure stemmed from the inability of opposition parties to collaborate after the Orange revolution. It was a result of a number of factors, both institutional and civic. Institutional factors are comprised of the constitution, the electoral system and the party system. Civic factors are comprised of cultural, ethnic differences in Ukraine and the short period of democratic experience within the country. This project will explore the relations between the type of Ukrainian opposition and the type of electoral system, the political party system and the political culture in the society.

Based on the existing literature and using primary sources of information, including the Ukrainian constitution and legislation, this paper will place the opposition of Ukraine within an existing typology and it will attempt to explain the role of the Ukrainian political opposition in relation to the political process. Lastly, this paper will attempt to suggest a solution for addressing problems of the effectiveness of the opposition within the political process. 
The research will use the available statistical data on the political parties including their numbers, years of existence, together with the results of the elections from the electoral commission of Ukraine and from official government publications. The publications will include the law on political parties, the law on parliamentary rules, and the law on the elections and the bill on the political opposition in Ukraine. This paper will test the basic hypothesis that the parties of the Ukrainian political opposition were successful in defeating the government in the 2004 presidential election but they were not effective because they could not create an alternative government due to a combination of four factors: (1) the character of the party system, (2) institutional structures based in the constitution, (3) the electoral system and (4) the political culture of society.

Based on the existing framework for the analysis of the political opposition in Western democracies by Robert Dahl and the more contemporary approaches by Alfred Stepan ${ }^{17}$, and Ludger Helms ${ }^{18}$, this paper will examine the relations between independent and dependent variables in the above-mentioned fours groups of variables and attempt to draw preliminary conclusions about their relative importance:

1) higher level of consolidation of the party system (independent variable, IV)- higher degree of effectiveness of the political opposition (dependent variable, DV);

2) the separation of power in a country's constitution (IV) - the greater the likelihood that the political opposition is institutionalised and effective (DV);

3) the more proportional the electoral formula of the electoral system (IV) - the greater the representation of the opposition parties in the parliament (DV);

\footnotetext{
${ }^{17}$ Alfred Stepan, "Democratic Opposition and Democratization Theory," Government and Opposition 32.4 (1997): 657-675.

${ }^{18}$ Ludger Helms, "Five ways of Institutionalizing Political Opposition: Lesson from the Advanced Democracies," Government and Opposition 39.1 (2004): 22-54.
} 
4) the more the political culture of society resembles the participant type of the political culture (IV) - the higher degree of effectiveness of the political opposition (DV).

Upon the results of observation and data analysis, this paper will attempt to reject the $\underline{\text { null }}$ hypotheses that the ineffectiveness of the parties of Orange team in Ukraine is not related to the structure of institutional and civic framework in Ukrainian governance, or to the party system, constitution, electoral system, and political culture.

The time period for the study is between 2002 and 2006. 2002 was the year of the parliamentary election in which the parties of the future Orange team participated as the opposition and were elected for the first time. 2006 was the year of the first post Orange revolution parliamentary election. The parties of the Orange team gained a majority of the votes in the Verkhovna Rada (Rada) in the 2006 parliamentary election but they failed to create a coalition government.

The thesis is organized as follows. The first chapter provides a theoretical analysis of classical academic approaches on the study of the political opposition and it provides the definition of the political opposition. The works of Robert Dahl, Alfred Stepan, and Ludger Helms on the political opposition in parliamentary systems are examined in relation to the definition of political opposition. They are also considered in conjunction with Shapiro's and Skilling's approaches to political opposition in one- party states as they apply to the specific case of Ukraine. The type of the political opposition in Ukraine is defined in relation to the above theories on the political opposition. From this analysis a set of criteria for testing the effectiveness of the political opposition in Ukraine will be developed. 
Chapter two analyzes the political party system in Ukraine and examines the relationship between the party system in Ukraine and the effectiveness of the parties in the political opposition. The working assumption is that if the parties of the Orange team were created around social cleavages in society and had an alternative policy and program to that of the government, combined with the personnel to govern, they would have been more cooperative during and after the election, and they would be able to form a coalition government.

Chapter three examines the influence of the political regime in Ukraine and the effectiveness of the political opposition. The working assumption is that the semipresidential regime with the presidential-parliamentary system of the governing prevented the formation of the effective political opposition.

Chapter four examines the relationship between the electoral system in Ukraine and the effectiveness of the political opposition. The main purpose it to test the influence of the electoral system on the ability of the parties of Orange team to be elected and proportionally represented in Rada during 2002 and 2006 parliamentary election.

Chapter five explains the character of Ukraine's political culture and its influence on the effectiveness of the parties of the opposition. It examines the system of the people's values, their attitude towards the main political institutions and their ability to cooperate and be united in influencing the government.

The conclusion provides the results of this research project. It will demonstrate whether the main hypothesis was confirmed or not and it will summarise the main findings. It then discusses the recommendations for future research on the subject of Ukrainian political opposition. 


\section{CHAPTER 1 \\ THEORY ON THE STUDY OF THE POLITICAL OPPOSITION AND ITS EFFECTIVENESS}

The definition of the political opposition has different meanings in different regimes. In established parliamentary democracies the political opposition is the political party or coalition of parties that did not win the elections and thus oppose the government and its policies. “... [I]n Western democracies opposition could be defined as a function of the division of voters or seats in legislative politics or in national elections." opposition's role is to control and challenge the government in the government's activity. The political opposition provides alternative policies to the current government and tries to defeat the incumbent party or coalition in the next election. "The ultimate goal for opposition in all democracies must be to influence mainstream politics and the policy priorities in a given country." 2 In this case the political opposition is defined as an institution". Ionescu defined the democratic political opposition as the "most advanced and institutionalized form of political conflict." ${ }^{4}$ Furthermore, the political opposition challenges the government and its policy, but does not reject the political system in which the political opposition operates. The institutionalized political opposition and the government are subject to the rule of law.

In Westminster parliamentary systems the opposition is the most defined form of opposition, where the line between the government and the opposition is clear and

\footnotetext{
${ }^{1}$ Barbara N. McLennan, ed., Political Opposition and Dissent (New York: Dunellen Publishing Company, Inc., 1973) 388.

${ }^{2}$ Eva Kolinsky, Introduction, ed., Opposition in Western Europe (Bechenham: Croom Helm Ltd., 1987).

3 This paper will use Guillermo O'Donnell's definition of the institution as “... a regularized pattern of interaction that is known, practiced, and accepted by actors who expect to continue interacting under the rules sanctioned and backed by that pattern." see Guillermo O'Donnell, "Illusion about Consolidation" in Consolidating the Third Wave Democracies. Themes and Perspective ed. Larry Diamond, Marc F. Plattner, (Baltimore: The Johns Hopkins UP, 1997) 40-58.

${ }^{4}$ Chita Ionescu, Isabel de Madariaga, Opposition, Past and Present of a Political Institution (London: C.A.Watts\&Co.Ltd., 1968) 9.
} 
opposition rights are understood. A leader of the opposition has official status and together with the official shadow cabinet tend to improve the government activity by holding government accountable to the parliament.

In presidential democracies such as France and USA, the political opposition is not institutionalized in the same way as in parliamentary democracies, but it does seek to defeat the government in elections. In these conditions the president represents the opposition to the legislative branch or in the case of France the president and the party of minority in the parliament are in the opposition to the government. ${ }^{5}$

The political opposition in non-democratic regimes can exist in different forms of protests or movements. The political opposition itself is defined as a "function of cultural criticism, popular movements, and general behavioural patterns demonstrating disrespect

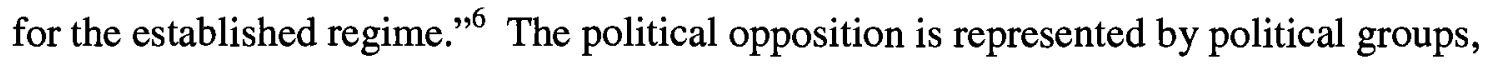
non-government organizations or social movements. This type of political opposition is less structured and institutionalized and does not participate in elections.

The political opposition in Ukraine has the characteristics of both institutionalized and non-institutionalized political opposition. The political opposition is represented by political parties and blocs that participate in elections, but the status of the political opposition in general has not yet been defined within Ukraine's institutional framework. Numerous recent electoral and constitutional reforms have not legislated on the definition and role of the political opposition in Ukraine.

For this research project, the definition of the political opposition used is the political party or coalition that has an alternative program to the government's policy

\footnotetext{
${ }^{5}$ Ludger Helms, "Five ways of Institutionalizing Political Opposition: Lesson from the Advanced Democracies," Government and Opposition 39.1 (2004): 22-54.

${ }^{6}$ McLennan 388.
} 
and makes efforts to introduce their programs and to defeat the government by

participating in fair elections. The political opposition is an institution and is subject to the rule of law. Only an institutionalized political opposition can provide a balance of power with the government, which can then strengthen a nation's democracy. An effective $^{7}$ parliamentary political opposition can prevent the government's monopoly of executive and legislative power by institutionalizing its own existence, activity and rights. Hence, the institutionalized political opposition can improve the development of important democratic features including civil society, the rule of law, minority rights as well as free and fair elections. ${ }^{8}$ Moreover, an effective and institutionalized political opposition can improve public trust in politicians and political institutions.

This study of political opposition in Ukraine will consider different approaches to the political opposition. Due to the current parliamentary-presidential system that exists in Ukraine this paper will review the classical works on the political opposition by Robert Dahl and Ludger Helms. Although a majority of contemporary works on the political opposition and its role cover party competition during elections in established mature democracies, they can inform the study of the Ukrainian parliamentary opposition and provide guidelines to assess its effectiveness, and offer suggestions for its improvement.

\footnotetext{
${ }^{7}$ Effective political opposition refers to a political opposition that has influence on government policy. An effective political opposition provides an alternative program to that of the government and has strong support from the electorate for the implementation of this program in the event of victory during the elections. The definition by Richard Hofstadter will be used in this paper. "When we speak of an opposition as being effective, we mean not merely that its program is expected to be capable of execution, that its alternative policy is real, but that its capability of winning office is also real, that it has the institutional structure and the public force which makes it possible for us to expect that sooner or later it will in fact take office and bring to power an alternative personnel." See Richard Hofstadter, The Idea of a Party System. The Rise of Legitimate Opposition in the United States, 1780-1840 (Berkeley: University of California Press, 1969) 5.

${ }^{8}$ According to the annual report by Freedom House, the rating for Ukraine's electoral process in 2006 was increased from 3.50 to 3.25 . The system is based on a scale from 1 to 7 where the 1 represents the highest and 7 the lowest level of democracy. Freedom House 16 October 2006

$<\mathrm{http}: / / \mathrm{www}$.freedomhouse.org/template.cfm?page $=47$ \&nit $=409$ \&year $=2006>$.
} 
In order to understand the potential and character of the political opposition in Ukraine, the influence of the one-party totalitarian regime that existed in its Soviet past must be considered. For this reason the works of Shapiro, Skilling and Stepan on the political opposition in one-party states and their role in developing democracy are vital for the analysis of the political opposition in Ukraine.

\subsection{Background of the Study of the Political Opposition}

The study of political opposition has its origins in the classical approach; this approach features the separation of powers and rule of law as key elements of a democratic society. Through their works, Aristotle, John Locke and later Montesquieu advanced the view that the separation of power forms a protection against tyranny.

The ancient Greek theory of democracy and participation was developed by Aristotle who first conceived the idea of power separation as an important element of democracy. In Aristotle's view;

All constitutions have three elements, concerning which the good lawgiver has to regard what is expedient for each constitution. There is (1) one element which deliberates about public affairs; secondly (2) that concerned with the magistracies - the question being, what they should be, over what they should exercise authority, and what should be the mode of electing to them; and thirdly (3) that which has judicial power.

Later Locke argued that in order to have legitimate government, the power of the state should be separated between the legislature and the executive. “... [L]imitations and restraints must be put upon the rulers' power and that there is a need of balancing the power of government, by placing several parts of it on different hands."10 In Locke's writings, he defined the separation of power as a guarantee against the tyranny of the government.

\footnotetext{
${ }^{9}$ Robert Maynard Hutchins, ed., Great Books of the Western World, The Works of Aristotle, vol. II (Chicago: Encyclopedia Britannica, Inc., 1952) 498.

${ }^{10}$ Edward J. Harpham, ed., John Locke's Two Treatises of Government (Lawrence: UP of Kansas, 1992) 42.
} 
... [I]n well ordered commonwealths, where the good of the whole is so considered as it ought, the legislative power is put into the hands of diverse persons who, duly assembled, have by themselves or jointly with others a power to make laws, which when they have done, being separated again, they are themselves subjects to the laws they have made; ${ }^{11}$

French political philosopher Montesquieu further refined Locke's theory and introduced the classic idea of "checks and balances" and "political liberty" 12 by separating the power between three branches of government: executive, legislative and juridical. Even though he supported the British model of governing (monarchy) in favour of the republican model, Montesquieu thought that it was vital and necessary to separate power in order to prevent tyranny and monopoly. "When the legislative and executive powers are united in the same person, or in the same body of magistracy, there can be then no liberty; ...there is no liberty, if power of judging be not separated from the legislative and executive powers." ${ }^{13}$ Centuries later, the belief that separation of powers within a state is the main criteria of a democratic regime endures.

\subsection{Robert Dahl on Political Opposition in Western Democracies}

According to Dahl, types of the political opposition and the opposition's effectiveness differs in societies based upon "constitutional structure and the electoral system; widely shared cultural premises; specific subcultures; the record of grievances against the government; and social economic differences."14 They are also influenced by

\footnotetext{
${ }^{11}$ John Locke, The Second Treatise of Government, An Essay Concerning the True Original, Extent and End of Civil Government (Oxford: Basil Blackwell, 1966) 73.

${ }^{12}$ Montesquieu defined the political liberty as the liberty of citizens under rule of law in a state. "Liberty is a right of doing whatever the laws permit ...liberty can consist only in the power of doing what we ought to will, and in not being constrained to do what we ought not to will." See Montesquieu, The Spirit of Laws, Part Two, Book XI (Berkeley: University of California Press, 1977) 200.

${ }^{13}$ Ibid., 202.

${ }^{14}$ Robert A. Dahl, ed., Political Opposition in Western Democracies (New Haven: Yale UP, 1966) 348.
} 
the character of social cleavages in society, the country's history and the level of polarization between its regions. ${ }^{15}$

Dahl defined the political party opposition as the most effective, united, and structured form of political opposition in comparison to other forms of political opposition. Dahl holds that political party opposition is institutionalized and is an active political actor in governmental decision-making process through participation in elections. Dahl defines three types of political opposition in parliamentary democracies based on the combination of different types of electoral systems with different types of party systems:

- strictly competitive opposition,

- cooperative-competitive,

- cooperative opposition. $^{16}$

The most effective political opposition in Dahl's view is the strictly competitive type because it is based on the two party-system and the plurality or first-past-the-post ${ }^{17}$ electoral system. In this case the opposition is represented by one or two political parties and it is more united in defeating the government. "The highest degree of opposition exists in two-party systems, where the out - party has a substantial monopoly of the opposition. In multiparty systems, opposition is likely to be dispersed among several parties." 18

Ukraine has a multi-party political system which, according to Dahl, should lead to a cooperative type of the political opposition. But this paper will argue that the multi-

\footnotetext{
${ }^{15}$ Ibid.

${ }^{16}$ Ibid., 336-338.

${ }^{17}$ Lawrence LeDuc, Richard G. Niemi, Pippa Norris, ed., Comparing Democracies 2, New Challenges in the study of Elections and Voting (London: Sage Publications, 2004) 42.

${ }^{18}$ Dahl 333.
} 
party political system in Ukraine did not support the cooperative type of the political opposition because of the character of the political parties' formation. The social cleavages in Ukrainian society are not a strong basis for the political parties' partisanship; electoral preferences are not stable, they are fluid. As Herbert Kitshelt stated in the study of the post-communist party systems, the personalized character of political parties and the clientelistic type of relationship between party and electorate take the place of program and ideology. ${ }^{19}$ Because of that, party competition is not program oriented and therefore able to provide a basis for cooperation between parties; rather it is based around leaders and their popularity. This personalistic basis of party competition has made compromises and coalition forming more difficult.

Nevertheless, this paper agrees with Dahl that political party opposition is more likely to be effective than does non-party political opposition within transition democracies. Even within a weak political party system the political opposition that is represented by a party has a greater likelihood to access power and to be influential than do political movements. By participating in the elections and providing its program and policy, the political opposition is legitimate in its activity. Furthermore, the political opposition should build its program on providing alternative policies to these of the government, not on rejecting current policy. In post-totalitarian countries this can be achieved, according to Stepan, by "transforming non-issues into issues"20 during the elections. In this case it can attract not only partisan supporters of the political party, but also undecided voters.

\footnotetext{
${ }^{19}$ See Herbert Kitschelt, Zdenka Mansfeldova, Radoslaw Markowski, Gabor Toka, Post-communist Party Systems. Competition, Representation, and inter-Party Cooperation (Cambridge: Cambridge UP, 1999) 47. ${ }^{20}$ Alfred Stepan, "Political opposition and democratization theory," Government and Opposition 32.4 (1997): 657-675.
} 
In regards to the institutional framework of the country, Dahl suggested that the parliamentary republic with a unitary system, as in Ukraine case, and a strong executive "with relatively great political resources in comparison with the legislature" ${ }^{\text {21 }}$ can create a strictly competitive type of the political opposition in combination with two-party system and single-member majority electoral system. The federal system in contrast, which features a weak executive, a multi-party system and proportional representation should result in a cooperative type of the political opposition.

However, Dahl's theory does not distinguish among the types of regime in a country. The separation of power in the well established democracies of Western Europe is not easy to achieve in transition countries such as Ukraine. Many post-totalitarian countries have mixed governing regimes. The separation of power takes place not only among the executive and legislative realms, as Dahl suggests, but within the executive branches. In the presidential-parliamentary and parliamentary-presidential systems in transition countries the executive power is separated between the president and the government that lead to "intra-executive competition." ${ }^{22}$ Furthermore, the constitutional separation of power is not effective when the constitution of a country is not respected and is a subject to constant changes from the election- winners. ${ }^{23}$ As G. O'Donnell ${ }^{24}$ suggests, in order to be democratically successful, the formal rules in the structure of

\footnotetext{
21 Dahl 35.

${ }^{22}$ Oleg Protsyk, "Intra-executive Competition between President and Prime-minister: Patterns of Institutional Conflict and Cooperation under Semi-Presidentialism," Political Studies 54(2006): 219-244, 227.

${ }^{23}$ For example, the law on the parliamentary rules, which describes the rights and responsibilities of the parliamentary coalition, was amended during the process of creating the parliamentary coalition in the summer of 2006, three months after the 2006 parliamentary elections. The full text of the law available at: <http://zakon1.rada.gov.ua/cgi-bin/laws/main.cgi?nreg=74-16>.

${ }^{24}$ Guillermo O'Donnell, "Illusion about Consolidation," Consolidating the Third Wave Democracies. Themes and Perspective, ed. Larry Diamond and Marc F. Plattner (Baltimore: The Johns Hopkins UP, 1997) 46.
} 
institutions should be respected and followed by political actors in their informal political behaviour. Referring to cases "... when informal rules are widely shared and deeply rooted" he notes that "it may be said that these rules (rather than formal ones) are highly institutionalized., 25

This leads to another important characteristic of the political opposition and its effectiveness according to Dahl's typology, which is relevant to Ukraine. In Dahl's view the history of the country and the relations between individuals inside the society could explain the type of political opposition in a country. He defined four types of relations in a society that are influential:

- orientations towards the political system ( allegiance; apathy and alienation)

- orientation towards other people ( trust or non-trust)

- orientation toward cooperation and individuality

- orientation toward problem-solving (empirical approach or rationalistic approach). ${ }^{26}$

Dahl advanced the hypothesis that the greater the levels of trust between people within society and toward that society's political institutions, the more effective and cooperative the political opposition. The opposite of this hypothesis holds true; the absence of trust can lead to a destructive and a revolutionary type of the political opposition. In order to succeed in the multicultural society, as in Ukraine's case, according to Dahl, the political opposition should unite the different groups by representing interests that are common to all groups. The political party opposition

\footnotetext{
${ }^{25}$ Ibid.

${ }^{26}$ Dahl 353.
} 
should not pose a threat to one region of the country or to a specific ethnic group, or religion, in order to win the support of the other.

To conclude, Dahl's work and his criteria for the political opposition, taking into account the transitional nature of Ukraine's democracy, are relevant and useful for an analysis of the Ukrainian political opposition. The constitution of the country, the electoral and the political party system are the leading characteristics from which the type of the political opposition in a country can be determined. There are two further characteristics that have particular significance for the study of Ukraine. The first is the character of the political culture in society and its influence on the relations between people and political institutions. The second is the ability of the political opposition to unite different regions, religions and ethnic groups in order to increase the pressure on the government.

\subsection{Ludger Helms on Institutionalized Political Opposition}

This author further developed Dahl's approach on the parliamentary political opposition in the modern established democracies of Western Europe. Helms ${ }^{27}$ classification contributes to the study of political opposition in Ukraine because it prescribes guidelines for new democracies to institutionalize parliamentary political opposition.

\footnotetext{
${ }^{27}$ Ludger Helms, "Five ways of Institutionalizing political opposition: lessons from the Advanced Democracies," Government and Opposition 39.1(January 2004): 22-54.
} 
Helms defined five types ${ }^{28}$ of parliamentary political opposition that are present in developed liberal democracies in Western Europe, based on the system of government that exists in a country. ${ }^{29}$

For the analysis of the political opposition in Ukraine, it is helpful to consider one of these, Helms model of the parliamentary-presidential political opposition in determining what is required to develop an institutionalized parliamentary opposition amid the flux of the country's constitutional changes. ${ }^{30}$ The parliamentary-presidential type of the political opposition can exist in the semi-presidential systems where there is a separation of power between a government that is responsible to the parliament while concurrently responsible to a directly elected president. Within a parliamentarypresidential system, in a "unified government", 31 the political opposition is represented by minority parties in the parliament. The political opposition does not have any influence on the policy of the government and as a result it can lead to the monopoly of the power by the president and the government. This type of political opposition does not ensure that there is transparency and accountability of the government due to the absence of any legal power by the minority parties in a parliament.

According to Helms, a more effective combination exists in the situation where the government and the president are represented by different political parties, the

\footnotetext{
${ }^{28}$ Parliament-centred opposition with no veto, parliament-centred opposition with strong veto, parliamentary-presidential opposition, separation-of-power opposition, direct-democratic model of opposition.

${ }^{29}$ The author based his typology on the five established democracies - Great Britain, Germany, France, United State and Switzerland.

${ }^{30}$ Ukraine's system of the government was changed from the presidential-parliamentary to the parliamentary-presidential republic in November 2004 (effective January 2006).

${ }^{31}$ Helms refers to the situation when the presidential party wins the parliamentary majority and create the Government. He uses the French model of governing as the example of the parliamentary-presidential political opposition.
} 
situation of the "cohabitation." 32 The political opposition is represented by the president and the minority parties in parliament. Despite the difficulties in finding compromises between the president and the parliamentary opposition, this type of the political opposition is influential on the government's activity. Helms provides France as an example where the president has a right to dissolve the National Assembly. The influence of the political opposition on the government in this case depends on the president's power of veto and this fosters the cooperative relations between the president, the political opposition and the government. This is reminiscent of the cooperative type of political opposition defined in Robert Dahl's typology. ${ }^{33}$

However, Helms argues that the presence of institutionalized political opposition, by itself, does not guarantee its involvement in the policy-making process. Helms implies that the effectiveness of the political opposition in developed parliamentary democracies depends on combinations of the institutional framework and political culture in society. This is similar to Dahl's condition that an effective political opposition requires the presence of "widely shared cultural premises in society."34

For the study of the political opposition in Ukraine Helms's work shows the necessity of collaboration between the president, the parliamentary opposition and the government in order for the policies to be passed in the semi-presidential systems with dual executive. This is representative of Ukraine's situation.

\footnotetext{
${ }^{32}$ The term cohabitation refers to the French system of semi-presidentialism that explains the situation when the President represents a different political party than the government and parliamentary coalition. On the meaning of cohabitation see Jean V Poulard, "The French Double Executive and Experience of Cohabitation," Political Science Quarterly 105.2 (Summer 1990): 243-267.

${ }^{33}$ Dahl 337.

${ }^{34}$ Dahl 348.
} 


\subsection{Leonard Shapiro and Gordon Skilling on Political Opposition in One-Party States}

To classify the type of Ukrainian political opposition and to evaluate its effectiveness, it is critical to consider the type of political regime that existed before independence. The origin of parliamentary political opposition in Ukraine also has roots in its recent history as a Communist one party state. Thus the classification of the political opposition in oneparty states by Leonard Shapiro and Gordon Skilling remains important in order to analyze the political opposition in present day Ukraine.

Shapiro defined the political opposition in one-party states as "an organised political group, or groups, of which the aim is to oust the government in power and to replace it by one of its own choosing." 35 According to Shapiro's typology, the opposition in one-party states can exist in the following forms: the "all-out" rejection of the communist system (revolutionary type); "power-struggle" in the form of one leader replacing another; "political dissent" opposition in the form of criticising the government on moral grounds, mostly from outside the country (soviet intelligentsia in 1960-1970ss); “interest groups" or "pressure group" activity.

The interest, pressure group type of the political opposition in Shapiro's view is the most effective type of political opposition. This type of the political opposition is represented by the organizations of technical, economic and academic elites outside of a party-state. The elite are the leaders of public opinion in a society and they increase the support for the political opposition among the masses by announcing their devotion to the ideas of the political opposition.

\footnotetext{
${ }^{35}$ Leonard Schapiro, ed., Political Opposition in One-Party States (London: The Macmillan press Ltd., 1972) 79.
} 
By exercising its activity outside governmental institutions, interest and pressure groups can represent civil society within the one-party state. Shapiro did not define this type of the political opposition as a civil society movement, but his explanation of the interest and pressure groups can be considered as a civil society activity. "An interest group seeks to exercise pressure on the government in order to promote its own interest. A pressure group on the other hand seeks to promote some policy or aim of a more general nature. ${ }^{\circledR 3}$ Hence, Shapiro's definition of the interest and pressure group type of the political opposition is reflected in the later work of Stepan on the political opposition in post-totalitarian countries. Stepan defined the "civil society against the state"37 political opposition as the most effective and democratic.

Gordon Skilling on the other hand provided a different typology of the political opposition in one-party states. According to Skilling the typology of the opposition in Communist Eastern Europe is the following: integral opposition (opposition to constitutional order or to the political system itself); factional opposition (opposition to the leaders in power); fundamental opposition (opposition to the policies of the regime), and specific opposition (opposition to the policies of the particular government but not to the regime itself).

While Shapiro suggested that the interest and pressure group type of political opposition is the most effective in the one-party state, Skilling argues that the inside-party opposition has a better chance in achieving its goals. In Skilling's view, the pre-eminent objective of any type of political opposition that exists within a one-party state is to gain

\footnotetext{
${ }^{36}$ Ibid., 7.

${ }^{37}$ Alfred Stepan, "Political Opposition and Democratization Theory," Government and Opposition 32.4 (1997): 657-675.
} 
the access to power or to the decision-making process. ${ }^{38}$ In one-party political regimes this can be accomplished through the "apparatchiki" or the so-called factional opposition. These are forces already represented in the government, e.g. the Politburo, ${ }^{39}$ and consequently they are in a superior position to influence the policies of the state. This type of political opposition in a one-party system can develop into a more democratic type of political opposition by peacefully providing recommendations to the ruling party and by creating an alternative program of public policy.

Furthermore, if the political opposition was represented in a country during oneparty rule then, in Skilling's view, it has a greater likelihood of developing into a democratic opposition in the future. This is comparable to Dahl's criteria for effective political opposition as possessing "a record of grievance against the government".

Even though the typologies developed by Shapiro and Skilling differ from Dahl's and Helms' typologies, all four writers share comparable substantive criteria for effective political opposition which may be summarized as:

1. Political opposition should be structured in order to be effective.

2. Political opposition should be able to create an alternative to the incumbent government by providing policies, without the rejection of the regime.

3. Political opposition should have strong support in society.

\footnotetext{
${ }^{38}$ Skilling based his hypothesis on the study of political interest groups in the Soviet Union and their ability to be influential on the government policy in comparison to the Western type of interest groups. See Gordon Skilling, Franklyn Griffiths, ed., Interest Groups in Soviet Politics (New Jersey: Princeton UP, 1971).

${ }^{39}$ Ibid., 40.
} 


\subsection{Conclusion}

In order to define the type of political opposition in Ukraine and to analyse its effectiveness, I will summarize the above classical approaches and synthesize their criteria for effective political opposition.

The first and most important condition for an effective political opposition is that the opposition be structured, organized, and united in its existence and in its action against the government. This condition can be tested by the analysis of the political party system and the character of political parties in Ukraine.

The second condition for an effective political opposition is the institutional framework of the country. This should provide for the separation of power; it should recognize the opposition and establish clear and strict rules for competitiveness between opposition and the government. This condition can be analysed by looking at the constitutional structure and electoral system of the country together with parliamentary regulation and procedures.

The third condition for a political opposition to be effective is the presence of nation wide societal values that are shared by a majority of the population. This condition can be tested by looking at the political culture of Ukraine's society; the level of support for the main governmental institutions, the level of the interpersonal trust between citizens and their ability to be united as a nation. 


\section{CHAPTER 2 \\ POLITICAL PARTY SYSTEM AND THE EFFECTIVENESS OF THE OPPOSITION}

The political party system of the country is the first and main characteristic that defines the type of the political opposition and its effectiveness. Dahl theorised that the twoparty political system is favourable for a strictly competitive political opposition because the boundaries between the government and the opposition are clear. "The highest degree of the concentration of opposition exists in two-party systems, where the out-party has a substantial monopoly of the opposition."1 To be effective, the party of the opposition should be able to form the government if it wins the election. In order to win the election the opposition party should have strong support within society for its program, which is a suitable and realistic alternative to that being offered by the government. The party of the opposition should demonstrate its ability to govern by providing an alternative program and the personnel necessary for the program's implementation.

When a state has a multi-party political system, the formation of a one-party parliamentary majority and thus a one-party government is rare and difficult to achieve. For this reason effectiveness requires that the parties of the opposition cooperate with each other or with the parties of the government. This is the cooperative type of opposition; this is what is necessary to form a parliamentary majority. In effect, the only way to govern is by coalition. "In multiparty systems strict competition is unlikely; in fact unless one party can form a majority by itself, strict competition is actually impossible."2

\footnotetext{
${ }^{1}$ Dahl 333.

${ }^{2}$ Ibid., 337.
} 
However, this typology does not take into account important characteristics including the level of institutionalization of the political party system, the political regime of the country, the character of the parties' formation and thus the basis for their competition. Political theories related to party systems, including Dahl's, are drawn from the experience of established democracies, where these systems are institutionalized. ${ }^{3}$

The multi-party system in Ukraine is comparatively uninstitutionalized. ${ }^{4}$ Its political parties are highly fragmented, their level of organization is weak, their support is tenuous in society and this leads to a high degree of electoral volatility. ${ }^{5}$ Nonetheless, these theories are still relevant and helpful, particularly as they relate to the origins of individual parties and their influence on the character of the party competition.

In order to answer the main research question (why did the Ukrainian political opposition parties fail to create an alternative effective government after the Orange revolution and 2006 parliamentary election?) this chapter will analyse the origin of the parties that comprised the future Orange team, the type of their formation and their social base. Using the classical approaches by Maurice Duverger on the origin of parties, by Herbert Kitschelt ${ }^{6}$ on the linkage between the party and electorate, and by Peter Mair ${ }^{7}$ on

\footnotetext{
${ }^{3}$ I mean the classical work by Maurice Duverger, Jean Blondel and Giovanni Sartori on the political party systems. See Maurice Duverger, Political Parties. Their Organization and Activity in the Modern state (London: Methuem \& Co Ltd., 1964), Jean Blondel, Political Parties. A genuine Case for Discontent? (London: Wildwood House, 1978), Giovanni Sartori, Parties and Party Systems. A Framework for Analysis, (London: Cambridge UP, 1976).

${ }^{4}$ Under the uninstitutionalised party system I use the definition by Sara Birch which defines it as follows: "Party systems may be considered uninstitutionalized if they are 1) highly fragmented, or 2) highly regionalised, such that different parties contest and win elections in different parts of the country." Sara Birch, Electoral Systems and Political Transformation in Post-Communist Europe (New York: Palgrave Macmilllan, 2003) 100.

${ }^{5}$ According to the Frank Thames' analysis on the party system institutionalization in the post-communist Russia and Ukraine, See Frank C. Thames, "Discipline and Party Institutionalization in Post- Soviet Legislature," Party Politics 13.4 (2007): 456-477.

${ }^{6}$ Herbert Kitschelt, "Formation of Party Cleavages in Post-Communist Democracies: Theoretical Propositions," Party Politics 1.4 (1995): 447-472, Herbert Kitschelt, Zdenka Mansfeldova, Radoslaw Markowski, Gabor Toka, Post-Communist Party Systems (Cambridge: Cambridge UP, 1999).
} 
the character of party competition, the following set of variables will be considered: the origin of the parties (age, size, and organization), their type of the formation (intra or extra-parliamentary, cadre party or mass party), their social base (region based or nation wide)and party competition (closed or open structure of the competition).

In order to assess whether the parties that made up the Orange team had alternative programs and the personnel to implement them, their program and positions on the main issues during the 2002 and 2006 parliamentary elections will also be reviewed. $^{8}$ The working hypotheses are:

H1: To the extent that parties are formed upon social cleavages in society, they will have stronger and more stable support for the implementation of their programs.

$\mathrm{H} 2$ : The divergences of goals of parties of the future Orange team, while in opposition, contributed to their lack of cohesiveness when in power.

H3: The presence of an alternative program to the program of the government, and of personnel to govern of the parties of future Orange team, would make it easier for them to cooperate to win the election and then to form a parliamentary majority.

The chapter concludes that the parties of the Orange team were not effective in creating an alternative government after the Orange revolution and the 2006 parliamentary election because they had no prior record of effective cooperation and had not been effective as a political opposition. There were a number of reasons for this. In the 2002 election the former presidential-parliamentary system ${ }^{9}$ did not provide

\footnotetext{
${ }^{7}$ Peter Mair, Party System Change, Approaches and Interpretations (New York: Oxford UP, 1997) 200224.

${ }^{8}$ The 2004 presidential election will not be reviewed in this chapter due to the non-party character of the position of the president.

${ }^{9}$ The institutional framework of the country, the constitution of Ukraine, the electoral system and their influence on the political opposition will be analyzed in the Chapters three and four. For that reason they will not be discussed in detail in this chapter.
} 
parliamentary parties constitutional rights to participate in the cabinet's formation. The cabinet itself was subordinate to the former non-party President Kuchma; any collaboration among the political opposition parties would not have resulted in influence on the government. Second, the non-mass character of the opposition parties' formation limited their activity to the leader's popularity, which prevented them from uniting behind one leader in the 2002 election. Third, the opposition parties campaigned separately in their own loyal regions. This was done to lessen the risk that they would lose support because the interests and beliefs of other allied opposition parties would offend their supporters, thus jeopardizing their election prospects. Last, prior to the 2002 parliamentary election, the political opposition parties had different strategies in achieving their goals; this weakened their collective effectiveness as a unified political opposition.

Despite institutional reforms during and after the Orange revolution, which might have been expected to encourage and assist in the coalition formation, this did not occur in the 2006 election after the Orange revolution. First, the fragmentation of the parties and blocs of the Orange team prevented the parties of the Orange team from uniting their forces in the 2006 election. Second, the regionalisation of the parties of Orange team continued to limit their cooperation with each other. Third, the absence of cooperation between the component blocs of the Orange was due to their different strategies in the election. Our Ukraine was the party of power in the election and wanted to preserve its power, while the Socialist party and the BYT (Bloc Yulia Tymoshenko) represented the structured opposition to the government and wanted to gain access to power. Finally, the lists of the parties and blocs' candidates during the elections suggested their continuation 
with the previous government rather than introduction of an alternative government. The presence of high number of members of the Kuchma government on the list of the parties of Orange team showed that the borderline between the opposition and the government was not clear. Thus the parties' collaboration would not bring a new effective and alternative government but rather the continuation of the old regime under a new name.

\subsection{Overview of the Political Party System in Ukraine}

Political parties are the key political actors in a democratic society. To be effective, political parties should represent different social groups and their interests; they should provide the link between the citizens and the government and vice versa. By voting for the political party and its program during the election an electorate is choosing the future government. The government, which is comprised of members of a political party, is more accountable to the public because the electorate can punish the governing party if its fails to deliver the electoral program it campaigned on during the election.

Because of its institutionalized existence and the activity of the political parties, the political party opposition is a more effective type of political opposition than interest groups and social movements. As Seymour Lipset stated:

Parties represent the only organized opposition that is prepared not only to challenge the power of the state but to actually assume office. Civil association do not represent the same kind of threat to the central authorities as an organized political opposition... Organized parties, in contrast, expressly intend to displace society's present rulers, and they seek to convince the public that they are capable of carrying out the functions of state, that they are not parochial in their interests. ${ }^{10}$

By being organized into political parties, the political opposition not only criticizes the government but it agrees to provide an alternative program, to govern and to compete for power in accordance with the institutional structure of the country.

\footnotetext{
${ }^{10}$ Seymour Martin Lipset, Jason M. Lakin, The Democratic Century (Norman: University of Oklahoma Press, 2004) 69.
} 
Ukraine has a multi-party political system which is considered the better choice for transition countries due to an ability of different social groups to be represented and compete for power. “... [T]he main path to democracy passes through the non-dominantparty limited multiparty system, which in turn has the strongest chance of becoming democratic."11 However, Ukraine's system of multi-partism prevented the formation of the cooperative and effective political opposition because of the weakness of the party system in general and the parties of the Orange team.

First, the weak political party system in Ukraine is illustrated by the high number of political parties; there were 137 as of December 2006. ${ }^{12}$ This fact contravenes the principle of the operative multi-party political system. Duverger foresaw this problem:

The multi-partism is often confused with absence of parties. A country in which opinions are divided amongst several groups that are unstable, fluid, and short-lived does not provide an example of multi-partism in the proper sense of the term. ${ }^{13}$

Electoral preferences are unstable when there are a high number of political parties as there were in Ukraine where 30 political parties contested the 1998 election, 33 competed in the 2002 election and 45 in the 2006 election. A large percentage of these parties were newly formed political blocs that appeared in the two to three year period before the election. In these conditions the majority of the electorate made its choice during the campaign rather than in accordance with party affiliation.

With so many parties in parliament, illustrated by continual shifting of party membership by deputies and extreme volatility of parties from election to election, citizens find it difficult to identify the parties and what programmatic positions they represent. ${ }^{14}$

\footnotetext{
${ }^{11}$ Axel Hadenius, Jan Teorell, “Pathways from authoritarianism," Journal of Democracy 18.1 (January 2007):143-156.

${ }^{12}$ As on the 20 December 2006, according to the site of the Central Electoral Commission of Ukraine 05 May $2007<$ http://www.cvk.gov.ua/paty/paty.htm>.

${ }_{13}^{13}$ Duverger 228.

${ }^{14}$ Robert K. Christensen, Edward R. Rakhimkulov, Charles R. Wise, "The Ukrainian Orange Revolution brought more than a new president; what kind of democracy will the institutional changes bring?"

Communist and Post-Communist Studies 38 (2005): 207-230.
} 
This in turn prevents the development of stable party supporters, which is a condition of a strong party system. Furthermore, a high fragmentation of the party system in combination with a high level of electorate volatility makes party competition in the election unpredictable or open. This open structure of competition is more the characteristic of a new emerging and unstable party system where the outcome of the election is unpredictable as a high number of new parties competes for office, the access to power for new parties is unlimited and alternation in the government is partial or nonexistent. $^{15}$

Figure 2.1

Number of Political Parties in the Elections, 1998-2006

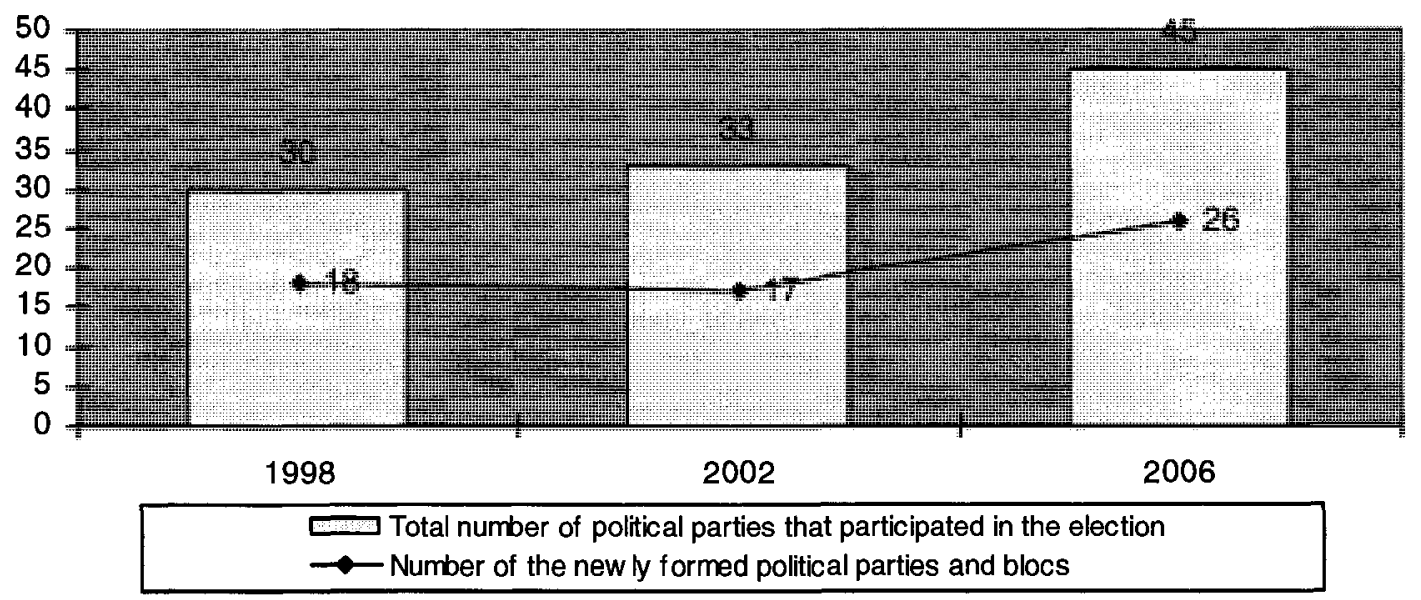

Source: graph produced by author based on data from the Central Electoral Commission of Ukraine, 15 May 2007 <http://www.cvk.gov.ua/pls/vd2002/webproc0v?kodvib=1\&rejim=0>, $<$ http://www.cvk.gov.ua/pls/vnd2006/W6P001>.

Second, the presence of multi-partism in Ukraine takes place under conditions where only a small percentage of the population are members of political parties. As the Figure 2.2 shows, the level of the population's involvement in any political or civil organizations was very low, with only $1.7 \%$ of the population that belonged to political

\footnotetext{
${ }^{15}$ According to the typology by Peter Mair, see Peter Mair, Party System Change, Approaches and Interpretations (New York: Oxford UP, 1997) 212.
} 
parties. $^{16}$ On the other hand, the percentage of the population that did not belong to any

civic or political organisations was $83.9 \%$. A high level of citizens' political

participation which is a condition for a strong and developed party system is not fulfilled

in Ukraine. ${ }^{17}$

\section{Figure 2.2}

Political Participation in Ukraine, 2004

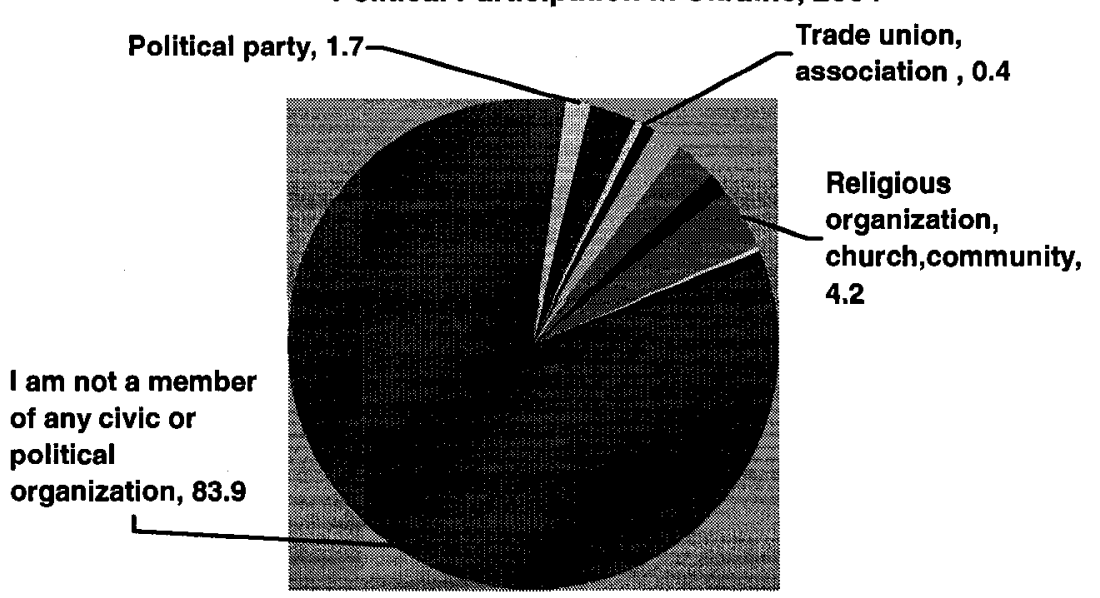

Club

Public-political movement

Public organization, foundation, association

Artistic union

Union of professionals (except traditional)

Religious organization, church,community

Other organization, union, movement

Political party
Ecological movement
Trade union, association
Sports club, society
Student society, youth organization
Sarmers' union
I am not a member of any civic or political organization

Source: chart produced by author based on the results of survey Ukrainian Society 1994-2004:

Sociological Monitoring (Institute of Sociology, National Academy of Sciences of Ukraine, Democratic Initiatives Foundation) 17 May 2007<http://dif.org.ua/modules/pages/files/us\%2094-04e.pdf>. The question was asked as "Which civil or political organization are you a member of ?" The sample size for the year 2004 was 1800 respondents in all oblasts of Ukraine and Crimea. The "sampling error" does not exceed $2.34 \%$.

Third, trust in the political parties as the representatives of the interests of different social groups is low and has never reached more than $1.1 \%$ of the population (see Figure 2.3), with a majority of the population distrusting political parties as institutions. Distrust in political parties is combined with an absence of support for the

\footnotetext{
${ }^{16}$ Only $0.4 \%$ of the population belong to trade union organizations, the representatives of the civil society, which will not be discussed in this study.

${ }^{17}$ The average percentage of the population that belongs to the political parties in the established democracies is varies from $2.5 \%$ in Great Britain, $6.3 \%$ in Canada and $10.5 \%$ in Sweden. World Value Survey 12 July $2007<h t t p: / / w w w . j d s u r v e y . n e t / b d a s e p j d s / Q u e s t i o n C r o s s t a b . j s p>$.
} 
multi-party political system, with $42.6 \%$ of the population opposed to the presence of the multi-party system in a 2004 survey. ${ }^{18}$ If the majority of the population does not belong to any political parties and do not trust the political parties as representing the citizens' interests, they can not support the political party system in which these political parties operate.

\section{Figure 2.3}

Level of Trust in Political Parties in Ukraine, 1994-2004

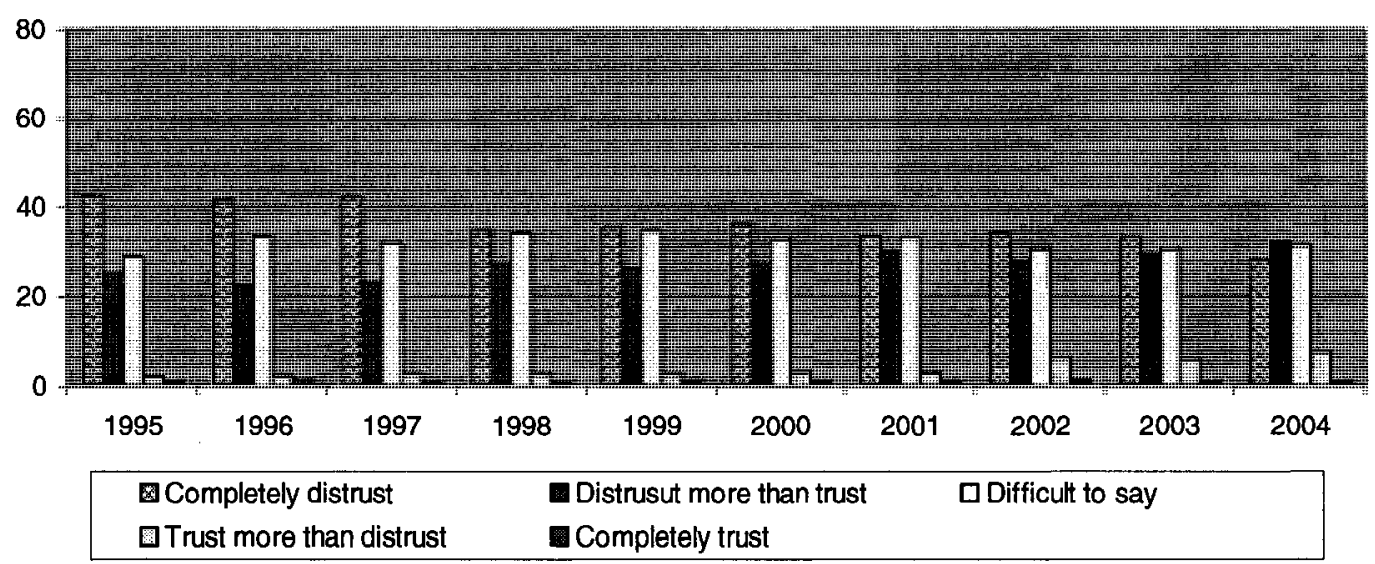

Source: graph produced by author based on the results of survey Ukrainian Society 1994-2004: Sociological Monitoring (Institute of Sociology, National Academy of Sciences of Ukraine, Democratic Initiatives Foundation) 03 May 2007<http://dif.org.ua/modules/pages/files/us\%2094-04e.pdf>. The question was asked as "How much trust do you have in political parties?"

Finally, the character of the political parties' formation and their non-mass character proved to be a weakness of the party system in Ukraine. As Herbert Kitschelt theorised in his work on the political party system in post-communist countries the programmatic parties that are formed around social cleavages in a society and which have high levels of support and membership among the citizens are most effective at consolidating democracy.

\footnotetext{
${ }^{18}$ Natalya Panina, ed., Ukrainian Society 1994-2004: Sociological Monitoring (Kyiv: Institute of Sociology, National Academy of Sciences of Ukraine, 2004) 14.
} 
Although programmatic parties are harder to build than charismatic or clientelistic parties, they are more likely to reinforce the consolidation and stability of democratic regimes than the two alternative (clientelistic and charismatic) modes of party - voter linkage. ${ }^{19}$

Contrary to this, in Ukraine, the political parties are formed top-down, on the basis of parliamentary factions led by a popular leader.

For example, of the 45 political parties and blocs that participated in the 2006 election, 26 were new electoral blocs ${ }^{20}$ that were formed in the period between elections and did not have any stable support in the society. ${ }^{21}$ Eight political blocs contained the name of their leader in their title such as BlocYulia Tymoshenko, People's bloc Litvina, bloc Lazarenka, bloc Natalii Vitrenko “Peoples’ Opposition”, electoral bloc “Eugen Marchuk - Unity", Ukrainian People's bloc Kostenko and Plushch, bloc Karamazina, bloc Boris Oliynik and Mikhaylo Syrota. ${ }^{22}$ For this reason the life span of parties is often limited to the period of the electoral campaign, or in the case of the leader-follower type parties, to the presence of the leader in the party. This undermines the role of the political parties as "the channel of communications from the state to the public; from the public to state and among different groups in civil society. ${ }^{, 23}$ The origin of the parties and the blocs of the future Orange team and the character of their formation also had influence on their effectiveness as the political opposition.

\footnotetext{
${ }^{19}$ Herbert Kitschelt, "Formation of Party Cleavages in Post-Communist Democracies: Theoretical Propositions," Party Politics 1.4 (1995): 447-472.

${ }^{20}$ New refers to the political parties and blocs that were formed less than four years prior to the parliamentary election. The Rada term was four years before the electoral reform in 2005 that changed it to five years.

${ }^{21}$ None of the above political blocs, except BYT was elected to Rada in 2006.

${ }^{22}$ The list of the political parties and blocs, that participated in the 2006 election. Central Electoral Commission of Ukraine 12 May 2007 <http://www.cvk.gov.ua/pls/vnd2006/W6P001>.

${ }^{23}$ Seymour Martin Lipset, Jason M. Lakin, The Democratic Century (Norman: University of Oklahoma Press, 2004) 64.
} 


\subsection{Origin of the Parties of the Orange team}

\subsubsection{The Socialist Party of Ukraine}

The Socialist Party of Ukraine is a founder of the leftist political opposition in independent Ukraine. Formed in 1991 after the ban of the Communist Party of Ukraine, the Socialist party was the main organisation representing leftist ideology in the country. It was, although modified, the continuation of the Communist party. This helped the Socialist party maintain access to the administrative resources and the support of a devoted Communist electorate:

If the parties regenerated, that is, transformed their organization and moderated their appeals, they became credible and critical competitors. They were less likely to be excluded from government and they had more capacity to criticize and to present alternatives to governing parties. ${ }^{24}$

After the reestablishment of the Communist party, the Socialist party lost a segment of its supporters and consequently its ideology shifted to the centre-left of the political spectrum. It also became the main critic of the government in the early 1990-s. "In December 1993 the party announced its opposition to the government that was represented by the President Kravchuk and Prime-Minister Kuchma." ${ }^{25}$ As Table 2.1 shows, the party represented the factional (opposition to the leaders) and fundamental (opposition to or criticism of policies of the regime) ${ }^{26}$ type of the opposition with its main goal to change the regime and replace the personnel of the government. ${ }^{27}$

\footnotetext{
${ }^{24}$ Anna Grzymala-Busse, "Authoritarian Determinants of Democratic Party Competition: The Communist Successor Parties in East Central Europe," Party Politics 12.3 (2006): 415-437, 417.

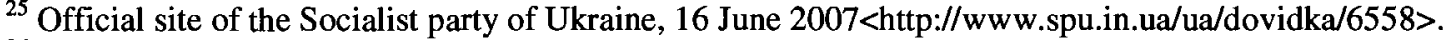

${ }^{26}$ According to the typology by Gordon Skilling. See Gordon Skilling, Franklyn Griffiths, ed., Interest Groups in Soviet Politics (New Jersey: Princeton UP, 1971).

${ }^{27}$ Oleksandr Moroz was one of the strongest supporters of the parliamentary system of governing in Ukraine.
} 
The Socialist party ideology is democratic socialism; its central objective is the introduction of the parliamentary system of governing together with a prominent role for state involvement in the distribution of social and economic goods. ${ }^{28}$

Although the Socialist party is one of the oldest parties in independent Ukraine and is considered a programmatic political party, it does not represent a mass-political party with a strong link to society. First, its formation occurred on the base of a parliamentary faction, making a top-down type of formation. Second, its activity mainly associated with its leader Oleksandr Moroz. The leader of the Socialist party is an experienced politician, who has participated, unsuccessfully, in three presidential elections. $^{29}$ The former Speaker of the Rada, from 1994 to 1998, Oleksandr Moroz was one of the authors and the initiator of the adoption of the Constitution of Ukraine on June, 28, 1996. The Socialist leader's personal opposition to President Kuchma initiated the "Kuchmagate" scandal ${ }^{30}$ in 2000 , one year after Moroz's second defeat in the 1999 presidential election, when Leonid Kuchma was re-elected to a second term. "The defeat greatly upset the leader of the socialists. Moroz accused Kuchma of the falsification of the results of the election and became his main opponent." 31 "Kuchmagate" led to the beginning of the mass protest movements "Ukraine without Kuchma", the National Salvation Front and finally the Orange revolution. After the 2006 election Moroz signed an agreement with the Party of Regions in exchange for the post of the Speaker of the

${ }^{28}$ Official site of the Socialist party of Ukraine, 16 June 2007 <http://www.spu.in.ua/ua/dovidka/6558>.

${ }^{29}$ Oleksandr Moroz participated in the 1994, 1999 and 2004 presidential elections and took third place in all of them. During the 2004 presidential election he supported Viktor Yushchenko in the second round.

${ }^{30}$ In the November 2000 Oleksandr Moros made public the tapes recorded by the ex-bodyguard of President Kuchma that had evidence of Kuchma's connection to the murder of the journalist Georgiy Gongadze. See Taras Kuzio, "Oligarchs, Tapes and Oranges: 'Kuchmagate' to the Orange Revolution," Journal of Communist Studies and Transition Politics 23.1 (March 2007): 30-56.

${ }^{31}$ Vita Andreychenko, "Oleksandr Moroz: from a mechanic-communist to the ally of Yanukovich," Ukrayinska Pravda 07 July 2006, 20 June 2007<http://www.pravda.com.ua/news/2006/7/7/44055.htm>. 
Rada which the Orange coalition did not provide him. This was also one of the main reasons behind the collapse of the Orange coalition in the Rada after the 2006 election. As with the leaders of Our Ukraine and the bloc Tymoshchenko, for Oleksander Moroz the decision about whether or not to collaborate with the Orange team depended on personal benefits rather than on the similarity of the party programs.

\subsubsection{Bloc Yulia Tymoshenko (party Fatherland)}

The name of the political bloc of Yulia Tymoshenko already suggests that it is a leaderfollower type of party formation. Tymoshenko was elected for the first time to the Rada in 1998 from the political party "Gromada",32, the party of ex- Prime-Minister Pavlo Lasarenko. ${ }^{33}$ She soon created her own political party Batkivshchina (Fatherland) in $1999,{ }^{34}$ a top-down party formation. Many members of Gromada switched to the Fatherland, trying to distance themselves from the disgraced Lazarenko. In the 2002 election the leader of the Fatherland party organized the electoral bloc bearing her name that included three other political parties. ${ }^{35}$ Under the same name but including five political parties the bloc participated in the 2006 election as well. (See Table 2.1) According to the official program of Fatherland, its ideology is based on a combination of the economic ideas of liberalism with the socialist ideas of social equality.

"Fatherland is a national, patriotic and a centrist party. It is a party of a new ideology that

\footnotetext{
${ }^{32}$ Tymoshenko was elected from the single-member majority district No 99 with the result $38.5 \%$. Central Electoral Commission of Ukraine 18 May 2007 <http://www.cvk.gov.ua/pls/vd2002/webproc0v?kodvib=1\&rejim=0>.

${ }^{33}$ Pavlo Lasarenko served as the prime-minister from May 1996 to July 1997. In 1998 he was denied the parliamentarian immunity and was accused of financial fraud.

${ }^{34}$ According to the Yulia Tymoshenko biography from personal web-site of Yulia Tymoshenko, 24 May $2007<\mathrm{http}: / /$ www.tymoshenko.com.ua/ukr/about/>.

${ }^{35}$ The political party "Sobor", the Ukrainian Republican Party and Ukrainian Social-Democratic Party.
} 
organically combines a social solidarity with the protection of a person's individual rights and freedoms."36

The party leader, Yulia Tymoshenko, is a good illustration of charismatic political leadership. Her electorate supported her in the role as leader of the opposition to President Kuchma in 2002 and then against her former ally President Yushchenko in 2006, the party's program was less important. "Many people know what the "NSF" 37 is, but the name of Yulia Tymoshenko is much better known in Ukraine.,"38 Having never experienced a prolonged period in the government ${ }^{39}$, Tymoshenko could take a populist stance in her criticism of the government; she espoused more radical opposition to the Kuchma regime than the other members of the Orange team. As Taras Kuzio described:

Why was Tymoshenko seen as such a threat in election year? With 200000 members, Tymoshenko's Fatherland Party, the cornerstone of her bloc, is stronger than any of the individual political parties who are members of Yushchenko's Our Ukraine. ${ }^{40}$

As for the type of opposition, the Tymoshenko party represented the factional (opposition to the leaders in power) and the specific (opposition to or criticism of the policies of the particular government) type of political opposition, with its main goal being to replace the incumbent government, but not the regime. ${ }^{41}$ According to the official site of the BYT, the party has 27 regional organizations and 250000 members, of which youth

\footnotetext{
${ }^{36}$ From the Official site of the BYT, 16 July 2007 <http://www.byut.info/ukr/about_a_party/foundations>. ${ }^{37}$ NSF - National Salvation Forum was the opposition movement in 2001 whose goal was to depose the Kuchma regime and to establish the parliamentary republic. Yulia Tymoshenko was among the founders of the NSF.

${ }^{38}$ Serhii Rakhmanin, Yulia Mostovaya, "Ukrainian political parties. Part III. Bloc Yulia Tymoshenko," Mirror Weekly No7, 23 February- March 2002, 20 June 2007 < http://www.mw.ua/1000/1550/33937/>. ${ }^{39}$ Yulia Tymoshenko was the Deputy Minister for the fuel and energy sector in the Yushchenko Cabinet from 1999 to 2001 and the Prime -Minister from January 2005 to September 2005. Both times she was dismissed by the President's decree.

${ }^{40}$ Taras Kuzio, "Oligarchs, Tapes and Oranges: 'Kuchmagate' to the Orange Revolution," Journal of Communist Studies and Transition Politics 23.1 (March 2007): 30-56, 49.

${ }^{41}$ According to the typology by Shapiro and Skiiling from the Chapter 1.
} 
represents $30 \%{ }^{42}$ The natural charisma, leadership and beauty of Yulia Tymoshenko attracted a large number of young people to the Fartherland party, which in turn widened the segment of the party's supporters. However, $51 \%$ of the party candidates during the 2002 and 2006 elections were between the age of 41 and $60{ }^{43}$ Tymoshenko is the youngest and only leader of the opposition who has a record of business experience,,$^{44} \mathrm{a}$ fact that has influenced her political actions as well. As the media portrayed her character, “...[S]he is the hardliner in the opposition leadership, the least willing to compromise and the one most ready to push the authorities to the limit."

\subsubsection{Bloc Our Ukraine, political party "People's Union Our Ukraine"}

The political bloc Our Ukraine is the youngest of the members of the Orange team. The electoral bloc Viktor Yushchenko Our Ukraine was organized on 09 January 2002 seven months after the dismissal of Yushchenko's cabinet ${ }^{46}$ and two months prior to the parliamentary election. Unlike the Socialist party and BYT, the bloc represented the extra parliamentary type of formation, one that took place outside the Rada and not on the basis of a parliamentary faction. It was formed around the potential presidential candidate Yushchenko and its program reflected the past achievements of Yushchenko, when he served as prime-minister, together with the promise of his future presidency. Despite the fact that the political bloc consisted of ten political parties during the 2002 election, as Table 2.1 shows, its name was associated with its leader, Viktor Yushchenko,

\footnotetext{
${ }^{42}$ Official site of the BYT 15 June $2007<h$ ttp://www.byut.info/ukr/about_a_party/foundations>. ${ }^{43}$ Central Electoral Commission of Ukraine 25 May 2007 <ttp://www.cvk.gov.ua/pls/vnd2006/W6P001>. ${ }^{44}$ Yulia Tymoshenko was the president of the gas-transit Company United Energy Systems of Ukraine (1995-1997) and is considered one of the wealthiest businesswomen in Ukraine. Official site of Yulia Tymoshenko, 24 May 2007<http://www.tymoshenko.com.ua/ukr/about/>.

${ }^{45}$ James Meek, "The millionaire revolutionary," The Guardian 26 November 2004, 7 March 2007 <http://www.guardian.co.uk/g2/story/0,3604,1359986,00.html\#article_continue>.

${ }^{46}$ Viktor Yushchenko was dismissed by a vote of no confidence by Verkhovna Rada in May 2001 because of his reforms that were touching the interests of oligarchs groups.
} 
who did not belong to any political party at the time of the election. Eight months prior to the election, none of the future bloc's member parties had more than $2 \%$ of national support in public opinion survey. ${ }^{47}$ Simultaneously, the support for Viktor Yushchenko was at $32 \%$ of the population. ${ }^{48}$ Thus the supporters of the bloc were the supporters of Viktor Yushchenko rather than the parties of the bloc, so the victory of the bloc in the 2002 election was Yushchenko's victory. ${ }^{49}$

The political party "Peoples' Union Our Ukraine", the continuation of the bloc Our Ukraine, was organized in March 2005, after the 2004 presidential election and the victory of non-party candidate Viktor Yushchenko and one year prior to the 2006 parliamentary election. The party was formed on the base of the political organization "For Ukraine! For Yushchenko!" headed by Petro Yushchenko, a brother of Viktor Yushchenko. The name of the party was adopted from the political party Our Ukraine (Party Reforms and Order), which was a member of the bloc Viktor Yushchenko Our Ukraine in the 2002 election. Roman Bezsmertniy, a close ally of former President Kuchma ${ }^{50}$ was chosen as the head of executive committee and President Yushchenko was voted the honorary leader of the party. The presidium of the party demonstrated its continuation with the previous regime as well. Among 21 members of the presidium five worked under President Kuchma, including his former press-secretary Mykola

\footnotetext{
${ }^{47}$ The question was asked as follows: "If an election took place today, which political party would you have voted for? In "Public Opinion about Political Leaders," Democratic Initiative Foundation Archive, 04 July 2001, 22 July $2007<$ http://www.dif.org.ua/ua/archive.vis\%20\%20\%20\%20\%20Democratic>. ${ }^{48}$ The percentage of respondents who said that they absolutely trust Viktor Yushchenko. The question was asked as follows: "How much trust do you have in Viktor Yushchenko?" 1- absolutely trust, 2-trust more than distrust, 3- absolutely distrust, 4- I do not know him, 5- difficult to say. "Public Opinion about Political Leaders," Democratic Initiative Foundation Archive, 04 July 2001.

${ }^{49}$ In the 2002 election electoral bloc Viktor Yushchenko garnered $23.6 \%$, the largest percentage of the vote form the proportional representation party list.

${ }^{50}$ Roman Bezsmertniy was the official representative of President Kuchma in the Verkhovna Rada from 1998 to 2001.
} 
Martinenko, former Vice-speaker Oleksandr Zinchenko and major of Kiev Oleksandr

Omelchenko. The rest of the presidium consisted of seven non-party ministers of the newly appointed cabinet and nine Peoples' Deputies, of whom four were non-party members. According to the official site of the party, the number of party members rose to $195000,{ }^{51}$ bringing together members of small parties such as Party of People Rukh of Ukraine, Party Unity, Youth Party of Ukraine, Social-Democratic Union, Party Solidarity, Party "Renaissance" and Party of the Defenders of the Motherland. (See Table 2.1) In the 2006 election the party and the bloc stood on the platform of economic liberalism and Ukrainian nationalism. ${ }^{52}$

The party showed its leader-follower character during the 2006 parliamentary election. While the constitutionally powerful non-party President Yushchenko did not have a need for party support and distanced himself from the party, Our Ukraine built its campaign on the continuation of his presidential program. Because of this, the bloc did not repeat its success of the 2002 election in 2006 . The diminished popularity of Yushchenko prior to the election and numerous changes in the leadership of the bloc cost Our Ukraine its victory in the election. ${ }^{53}$

An additional problem for parties that have spawned and supported a personalized or pseudocharismatic leadership is that even as the leader leaves office, and has lost authority in the eyes of voters and party members, it is difficult to silence him or her, and such former leader continue to have significant impact on the image of the party. ${ }^{54}$

\footnotetext{
${ }^{51}$ Official site of Party "Peoples Union Our Ukraine" 06 July 2007 $<$ http://www.razom.org.ua/en/static/nsnu/>.

52 Official program of the political bloc Our Ukraine in the 2006 election. Central Electoral Commission of Ukraine 23 July $2007<$ http://www.cvk.gov.ua/pls/vnd2006/printblob?pf7171=20\&kodvib=600>.

${ }^{53}$ According to the result of social monitoring by the Democratic Initiative Foundation in SeptemberNovember 2005, the rating of Our Ukraine was changing constantly due to changes in the leadership of the bloc. For the full text see "Round table: opinions and attitude of the Ukrainian population - November 2005" Democratic Initiative Foundation Archive, 05 December 2005.

${ }^{54}$ Juan J. Linz, "Parties in Contemporary Democracies: Problems and Paradoxes," Political Parties. Old Concepts and New Challenges, ed. Richard Gunter, Jose Ramon, Montero, Juan J. Linz (New York: Oxford UP, 2002) 303.
} 
Table 2.1 Political Parties of the Orange team

\begin{tabular}{|c|c|c|c|c|c|c|c|c|}
\hline $\begin{array}{l}\text { Name of the } \\
\text { political } \\
\text { party, bloc }\end{array}$ & $\begin{array}{l}\text { Year } \\
\text { of } \\
\text { origin }\end{array}$ & Leader & $\begin{array}{l}\text { The } \\
\text { number } \\
\text { of the } \\
\text { party } \\
\text { members } \\
\text { (size of } \\
\text { party)* }\end{array}$ & Ideology & $\begin{array}{l}\text { Number of } \\
\text { election that } \\
\text { party, bloc } \\
\text { participated }\end{array}$ & $\begin{array}{l}\text { Type of } \\
\text { oppositio } \\
\text { n }\end{array}$ & $\begin{array}{l}\text { Goal as the } \\
\text { opposition }\end{array}$ & $\begin{array}{l}\text { Numbe } \\
r \text { of } \\
\text { parties } \\
\text { in the } \\
\text { bloc }\end{array}$ \\
\hline $\begin{array}{l}\text { Socialist } \\
\text { Party of } \\
\text { Ukraine }\end{array}$ & 1991 & $\begin{array}{l}\text { Oleksandr } \\
\text { Moroz }\end{array}$ & 30000 & $\begin{array}{l}\text { Centre- } \\
\text { Left, } \\
\text { Democrati } \\
\text { c } \\
\text { socialism }\end{array}$ & $\begin{array}{l}1994,1998, \\
2002,2006\end{array}$ & $\begin{array}{l}\text { Factional, } \\
\text { fundamen } \\
\text { tal }\end{array}$ & $\begin{array}{l}\text { Replacement of } \\
\text { the regime } \\
\text { together with the } \\
\text { personnel of the } \\
\text { government }\end{array}$ & \\
\hline $\begin{array}{l}\text { Party } \\
\text { Fatherland, }\end{array}$ & 1999 & $\begin{array}{l}\text { Yulia } \\
\text { Tymoshenko }\end{array}$ & 250000 & $\begin{array}{l}\text { Right- } \\
\text { centre } \\
\text { Liberalis } \\
\text { m }\end{array}$ & 2002,2006 & $\begin{array}{l}\text { Factional, } \\
\text { specific }\end{array}$ & $\begin{array}{l}\text { Replacement of } \\
\text { the incumbent } \\
\text { govern-t without } \\
\text { the regime change }\end{array}$ & \\
\hline $\begin{array}{l}\text { Bloc Yulia } \\
\text { Tymoshenko }\end{array}$ & 2001 & $\begin{array}{l}\text { Yulia } \\
\text { Tymoshenko }\end{array}$ & & & 2002,2006 & $\begin{array}{l}\text { Factional, } \\
\text { specific }\end{array}$ & & $5 * *$ \\
\hline $\begin{array}{l}\text { Bloc Viktor } \\
\text { Yushchneko } \\
\text { "Our } \\
\text { Ukraine" } \\
\end{array}$ & $\begin{array}{l}\text { January } \\
2002\end{array}$ & $\begin{array}{l}\text { Viktor } \\
\text { Yushchenko }\end{array}$ & & $\begin{array}{l}\text { Right- } \\
\text { Centre, } \\
\text { Liberalis } \\
\mathrm{m} \\
\end{array}$ & 2002,2006 & Loyal & $\begin{array}{l}\text { To criticize the } \\
\text { policy without } \\
\text { rejecting the } \\
\text { regime }\end{array}$ & $10^{* * *}$ \\
\hline $\begin{array}{l}\text { Party People } \\
\text { Union } \\
\text { Our Ukraine }\end{array}$ & $\begin{array}{l}\text { March } \\
2005\end{array}$ & $\begin{array}{l}\text { Roman } \\
\text { Bczsmertniy } \\
\text { Vyacheslav } \\
\text { Kirilenko }\end{array}$ & 195000 & $\begin{array}{l}\text { Right- } \\
\text { Centre, } \\
\text { Liberalis } \\
\mathrm{m}\end{array}$ & 2006 & $\begin{array}{l}\text { Party of } \\
\text { president }\end{array}$ & & $6 * * * *+$ \\
\hline
\end{tabular}

Source: table produced by author based on data from the official site of the BYT, 08 July 2007

$<$ http://www.byut.info/ukr/about_a_party/history>, Official site of the Socialist Party of Ukraine 08

July2007, <http://www.spu.in.ua/ua/press/4973>, Official site of the political party "People Union Our

Ukraine" 08 July $2007<$ http://www.razom.org.ua/en/static/nsnu/>.

* The information about the membership of parties was used from the official site of the parties.

** Ukrainian People's Party Assembly, Ukrainian Republican Party, Ukrainian Social Democratic Party,

Fartherland Party.

***CCongress of Ukrainian Nationalists, Liberal Party of Ukraine, The Youth Party of Ukraine, People Rukh of Ukraine, Party Our Ukraine( Party " Reformi ta poryadok'), Party "Unity", Party Democratic-Christian Union, Political Party "Forward Ukraine", Republican Christian party, Ukrainian People party ( Ukrainian People Rukh)

**** Congress of Ukrainian Nationalists, Peoples' Movement of Ukraine, People's Union “Our Ukraine”, Ukrainian Republican Party "Sobor", Party of Industrialists and Entrepreneurs

+ Party People Union Our Ukraine is the successor of the bloc Our Ukraine

\subsection{The Social Base of the Parties of the Orange team}

In order to mobilize the electorate, influence the policy of the government, and more importantly to become the national government, the parties of the opposition should have the support from nation-wide social groups. They can not claim the authority to govern the whole nation if they have support only in one part of the country. The political parties of the Orange team, however, did not satisfy this criterion, and this limited their effectiveness. "Ukraine had a plethora of parties ready to engage in these 
elections, but hardly any that could be called national parties in the sense of their having full-scale, country-wide organization." ${ }^{, 55}$ According to the polls by the Kiev International Institute of Sociology prior to the 2002 parliamentary election the bloc Our Ukraine had as much as $58.1 \%$ support in Western Ukraine and only $4.00 \%$ in Eastern Ukraine. ${ }^{56}$ Moreover, 52.5\% of the bloc's supporters during 2002 election resided in the country side, one of the groups who most strongly supported the presidential candidate Yushchenko in the 2004 election. $^{57}$

The same was true about the BYT, which had stronger support in the central regions and less than $1 \%$ in the south-eastern regions. On the other hand, the Socialist party of Ukraine had substantial support in the eastern regions and only $0.3 \%$ in the Western regions.

The results of the 2002 parliamentary elections demonstrated the regionalized character of the political opposition parties in Ukraine. From the 27 regions of Ukraine, bloc Our Ukraine was the leader on the proportional representation party list in only 15 regions. These were mostly Western oblasts and in the city of Kyiv. The percentage of the votes that the bloc received in the south-eastern regions was highest in Crimea at 9.77\%, and as low as $2.69 \%$ in the Donetcskya oblast. ${ }^{58}$ The Socialist party of Ukraine was a leader in the Poltava oblast with the $22.05 \%$, but had less than $4 \%$ of the votes in ten regions of the country. The BYT gained $18.83 \%$ in the Western Ternopilskya region but did not reach the $4 \%$ threshold in the southeastern regions.

\footnotetext{
${ }^{55}$ Bohdan Harasymiw, "Elections in Post-Communist Ukraine, 1994-2004: Overview," Canadian Slavonic Papers XLVII. 3-4 (September-December 2005): 191-240.

56 "Round table: 2002 election, last ratings and forecast," Democratic Initiatives Foundation Archive, 14 March 2002.

${ }^{57}$ Ibid.

${ }^{58}$ According to the official results of the 2002 election in the regions of Ukraine, Central Electoral Commission of Ukraine 10 June $2007<$ http://www.cvk.gov.ua/pls/vd2002/webproc0v>.
} 
The regionalisation of the parties of Orange team was a reason for their ineffectiveness in the post-revolution period. In the 2006 election the bloc Our Ukraine took third place with $13.95 \%$ of the vote nation wide. This was achieved mostly in three Western regions, Lvivlska, Ivano-Frankivska and Zakarpatska oblasti, where the bloc was a leader. The BYT took second place in the election with $22.23 \%$ of vote nation wide. From the total number of 27 regions, the bloc was led in 14 regions. However, as in the 2002 election, the level of the support for the bloc in the southeastern regions was low; in the Donetskaya and Luhanksy oblasts it received $2.47 \%$ and $3.71 \%$ of the votes, respectfully. The Socialist party took the fourth place in the election with $5.63 \%$ of the vote. The percentage of the vote that party received varied from $0.81 \%$ in the Southern city of Sevastopol to $14.69 \%$ in the Central Vinnitskya oblast. ${ }^{59}$

This regionalization of the political opposition parties limited their effectiveness. "Ukraine's regional and linguistic divide negatively influences the ability of opposition groups to mobilize national support." ${ }^{160}$ The political opposition parties can not claim the authority of the national government if their support is limited to specific regions in the country.

\subsection{Party competition from 2002 to 2006}

\subsubsection{2 parliamentary election}

The main issues of the 2002 parliamentary election were related to the future presidential election in 2004 and the replacement of the incumbent President Kuchma, whose second term ended in 2004. Because of the Kuchmagate scandal, which happened prior to the

\footnotetext{
${ }^{59}$ Official result of the 2006 election, Central Electoral Commission of Ukraine 20 August 2007 $<$ http://www.cvk.gov.ua/pls/vnd2006/W6P001>.

${ }^{60}$ Taras Kuzio, "Oligarchs, Tapes and Oranges: 'Kuchamgate' to the Orange Revolution,” Journal of Communist Studies and Transition Politics 23.1 (March 2007): 30-56.
} 
election, the parties' position on the alleged connection of Kuchma to the murder of the journalist Gongandze significantly influenced the tone of the campaign. This fact also divided the parties of the opposition from the beginning. Opposition parties had different positions toward the main issue of campaign - President Kuchma. Their goals also differed. The BYT and the Socialist party represented the factional (opposition to the leaders in power), specific (opposition to the particular government) and fundamental (opposition to or criticism of the policies of the regime) ${ }^{61}$ type of political opposition; they acted through mass actions, protests and through the pressure groups. ${ }^{62}$ Both included the introduction of the law on the impeachment of the president in their electoral program. The socialists also included a proposal on the future system of parliamentarism. "We will increase the role of the parliament and cabinet independence. We will introduce the law on the impeachment of the president., ${ }^{, 63}$ Viktor Yushchenko's political bloc Our Ukraine was formed as an opposition bloc in the beginning of 2002; nevertheless, the bloc never took the side of the radical opposition to President Kuchma. As Taras Kuzio described: "Yushchenko and Our Ukraine never supported Ukraine without Kuchma, never gave their full support to Arise Ukraine ${ }^{64}$ and never coordinated their activity with the other three opposition groups. ${ }^{.65}$ Furthermore, Yushchenko

\footnotetext{
${ }^{61}$ Gordon H. Skilling, "Background to the Study of Opposition in Communist Eastern Europe," Political Opposition in One-Party states, ed. Leonard Schapiro (London: The Macmillan press Ltd., 1972) 76.

62 Tymoshenko was one of the main initiators of the creation on March, 09, 2001; The National Salvation Forum, the organization against the regime of President Kuchma.

${ }^{63}$ The official program of the Socialist party of Ukraine, Central Electoral Commission of Ukraine 18 June $2007<$ http://www.cvk.gov.ua/pls/vd2002/printblob?pf7171=139\&kodvib=400>.

${ }^{64}$ The Ukrainian civic protest movement Arise Ukraine was created in September 2002, two years after the murder of the journalist Georgiy Gongadze. The main goal of the protest was to initiate the impeachment of President Kuchma. The agreement for the beginning of the protest was signed by BYT, the Socialist party of Ukraine and the Communist party of Ukraine.

${ }^{65}$ Taras Kuzio, "Oligarchs, Tapes and Oranges: 'Kuchmagate' to the Orange Revolution," Journal of Communist Studies and Transition Politics 23.1 (March 2007): 30-56.
} 
himself insisted on his non-participation in the opposition to the government as Ukrainian media reported:

He kept insisting that he couldn't be an opposition leader, that opposition is built on negation, that his bloc unites creators, not destroyers, that he respected Yuliya Tymoshenko and her comrades, but "Our Ukraine" [election bloc led by Yushchenko] was a self-sufficient organization that needed no support from the regime's opponents. ${ }^{66}$

The parties' different goals were an impediment to their collaboration.

Second, the character of the parties and the blocs' formation prevented their unity. Due to the leader-follower formation, the main distinction between the two electoral blocs (BYT and bloc Viktor Yushchenko Our Ukraine) was the name of their respective leaders rather than their ideologies. "His [Yushchenko] election bloc was formed on the principle of gratitude. He offered the coverage under the umbrella of his popularity to everyone who had supported him during the April 2001 crisis." ${ }^{, 67}$ The creation of the coalition would have required concessions from one of the two leaders. Tymoshenko and Yushchenko were not ready for that. Furthermore, bloc Viktor Yushchenko Our Ukraine built its campaign on the positive image of Viktor Yushchenko as the future presidential candidate with the positive message "I Believe. I Know. I Can. We did it a year ago and we will defend the interests of the simple person again." 68

Third, with the exception of the Socialist party, the members of the political opposition in the 2002 election were represented by electoral blocs, not parties. This fact complicated the process of collaboration among the parties of political opposition. Tymoshenko and Yushchenko had already negotiated and compromised to form their blocs that consisted respectively of four political parties in the BYT and ten political

\footnotetext{
${ }^{66}$ Serhii Rakhmanin, Yulia Mostovaya, "Ukrainian political parties. Part III. The Yulia Tymoshenko Bloc," Mirror Weekly No7, February- March 2002, 19 June 2007<http://www.mw.ua/1000/1550/33937/>.

${ }^{67}$ Serhii Rakhmanin, Yulia Mostovaya, "Ukrainian political parties. Part II. Bloc Our Ukraine," Mirror Weekly No 6, February 2002, 20 June $2007<$ http://www.mw.ua/1000/1550/33858/>.

${ }^{68}$ From the official program of the bloc Viktor Yushchenko "Our Ukraine."
} 
parties in the bloc Our Ukraine. (See Table 2.1 again) The formation of the wide

coalition would have been required even more compromise between already unwieldy

blocs.

Usually such "alliances to win power" have little in common when it comes to ideology, ethnic needs or corporate backing. Their leadership are often personalised and fractious and their members are driven by very different interests and goals 69

Finally and most importantly, the non-party character of the cabinet and its

dependence on the power of the non-party president undermined the value of party

politics, party government and party alteration, which are key elements within a

parliamentary democracy. In the conditions of the presidential-parliamentary system that

existed in 2002 prior to the 2004 constitutional reform ${ }^{70}$, the role of the political parties

was limited. So was the influence of the parties of the opposition. As political theorist

Juan Linz defined "Parties in presidential systems are less likely to articulate government

programmes and broad public policies - functions which are more likely to be performed

by presidents."71 It was not necessary for the political parties, including the opposition

parties, to collaborate in the election.

If one assumes that the primary goal of a political party is to gain the largest number of seats possible to gain control of the legislative agenda, then there is less rationale for a political party to attempt to do so when the parliamentary control of the legislative agenda is undermined by the existence of a president with the powers to legislates by decree. ${ }^{72}$

\footnotetext{
${ }^{69}$ John Carey, Andrew Reynolds, "Parties and Accountable Government in New Democracies," Party Politics 13.2 (2007): 255-274.

${ }_{70}$ The constitutional reform of 2004 , in force since January 2006 , changed the system from a presidentialparliamentarian structure to parliament-presidential one. The parliament was granted the power to form the cabinet from the parliamentary party-based coalition. The institutional framework of Ukraine and its influence on the effectiveness of the political opposition will be discussed in Chapter 3.

${ }^{71}$ Juan J. Linz, "Parties in Contemporary Democracies: Problems and Paradoxes," Political Parties. Old Concepts and New Challenges, ed. Richard Gunter, Jose Ramon Montero, Juan J. Linz (New York: Oxford UP, 2002) 292.

72 Terry D. Clark, Jill, N Wittrock, "Presidentialism and the Effect of Electoral Law in Postcommunist systems: Regimes Type Matters," Comparative Political Studies 38.2 (March 2005): 171-188.
} 
The main goal of the opposition parties in the 2002 election was to prepare the electorate for the future presidential election, which they hoped to win. Having been elected to the Rada in the parliamentary election, the parties of the political opposition and their leaders had better opportunities to mobilize and inform the public about their future plans.

\subsubsection{6 parliamentary election}

The 2006 parliamentary election took place on March 26, 2006. It was the first election after the Orange revolution and under the presidency of Viktor Yushchenko. It also was the first election that happened after the constitutional reform 2004 that transformed the presidential-parliamentary system to the parliamentary- presidential system of the governing. The parliamentary coalition in the Rada and the parties that constituted it obtained the right to appoint and dismiss the prime-minister and his/her cabinet. Moreover, the mixed electoral system was replaced by the proportional representation closed party list. The country was divided into 225 territorial districts and the parties that obtained at least $3 \%$ of the popular vote cast by the electorate were elected to the Rada. These institutional changes may have been expected to increase the role of the political parties in the political process. However this did not emerge.

Even though the institutional framework of the country changed it did not change the parties' ineffectiveness. The constitutional reform in 2004 transformed the 2006 parliamentary election into an election for the new constitutionally powerful primeminister. All three leaders of Orange team hoped for the future post of the prime-minister and for that reason they did not want to share power with their former allies. Tymoshenko stated, "I can say with confidence that I dream to get to parliament with a 
kind of force that I would not have to create coalitions. Coalitions are always compromises against peoples' interests." ${ }^{73}$ The Orange team was united in its desire to reach power in the 2004 presidential election to replace President Kuchma, but they were not unified in sharing the power with each other in the circumstances leading to the 2006 election.

Second, the former members of the Orange team came to the parliamentary election with different goals. In the 2006 election Our Ukraine was the party of power. Hence the goal of the party was to preserve its position in the government; its strategy was not to replace the incumbent government, but rather to increase the party representation in the Rada. Our Ukraine declared membership in the World Trade Organisation (WTO), a professional army by 2010 and future membership in NATO to be the main priorities of their government, ${ }^{74}$ reflecting Yushchenko's 2004 support for European integration and the collaboration with NATO. ${ }^{75}$

BYT and the Socialist party of Ukraine represented the loyal opposition to the Yushchenko government. After her dismissal by the president as the prime-minister in September 2005, Yulia Tymoshenko was in political opposition to the government again. Although her bloc had common ground with bloc Our Ukraine on the subject of privatization and separation of government and business, Tymoshenko built an electoral campaign on the promise of fair government and an indirect criticism of the Yushchenko

\footnotetext{
${ }^{73}$ From a television interview of Yulia Tymoshenko on February 27, 2006 in Donetsk. Official site of Yulia Tymoshenko, 24 May $2007<h$ ttp://www.tymoshenko.com.ua/ukr/news/elections-news/2826/ >.

${ }^{74}$ The official program of the bloc Our Ukraine during 2006 election. Central Electoral Commission of Ukraine 16 May 2007 <http://www.cvk.gov.ua/pls/vnd2006/printblob?pf7171=20\&kodvib=600>.

${ }^{75}$ From the program of the presidential candidate Viktor Yushchenko. Official site of Viktor Yushchenko 23 May $2007<h t t p: / / w w w . y u s c h e n k o . c o m . u a / u k r / F u t u r e / 206 />$.
} 
presidency ${ }^{76}$ BYT wanted to change the personnel of the government, making the bloc a "non-structural",77 type of political opposition.

The Socialist party supported the idea of a close collaboration with Russia and government intervention in the process of privatization, free education and health care. ${ }^{78}$ The question of Ukraine's entrance into NATO according to the socialist program was to be the subject of a national referendum. Thus the party represented a structured opposition, ${ }^{79}$ whose main goal was to introduce new policies and to change the socioeconomic structure but not the personnel of the government. ${ }^{80}$

Third, the problem of bloc fragmentation was once again apparent in 2006, inhibiting collaboration of previously allied groups. Bloc Our Ukraine consisted of six political parties that were united under the name of the bloc, as Table 2.1 shows. Three of the political parties, People's Union "Our Ukraine”, Ukrainian Republican Party "Sobor" and the Party of Industrialists and Entrepreneurs, appeared for the first time in the bloc. The Ukrainian People Party, which was in the bloc during the 2002 election participated as a member of the newly formed Ukrainian People bloc Kostenko and Plushch. The Party "Reforms and Orders" also left the bloc and created a bloc "Civil Political Bloc Pora- Reforms and Order Party." The Liberal party of Ukraine, a member of the bloc in 2002, participated separately in the election.

\footnotetext{
${ }^{76}$ Tymoshenko promised to review the Treaty between Ukraine and Russia on the subject of gas supply to Ukraine that was signed by the Yushchenko' government in January 2006. See "Ukraine's Former PM To Challenge Gas Deal In Courts," Radio Free Europe 05 January 2006, 14 June 2007 <http://www.rferl.org/featuresarticleprint/2006/01/e914e4d3-3b0a-4de9-84bc-9cad6b778f2c.html>. ${ }^{77}$ Dahl 342.

${ }^{78}$ The official program of the Socialist Party of Ukraine during 2006 election. Central Electoral Commission of Ukraine 16 May 2007 <http://www.cvk.gov.ua/pls/vnd2006/printblob?pf7171=26\&kodvib=600>.

${ }^{79}$ Dahl 342.

${ }^{80}$ At the time of the 2006 election members of Socialist party were represented in the Cabinet.
} 
BYT also was formed by two political parties, Fatherland and the Ukrainian Social-Democratic Party. The Ukrainian Republican Party "Sobor", a part of the bloc in 2002 election, switched to the bloc Our Ukraine. The scope of the coalition would create potential problems in the future distribution of ministerial positions in the event of victory. The central parties of the Orange team were not prepared for this.

The Socialist party of Ukraine only once before the 2006 election joined an electoral bloc, with the Peasant party of Ukraine in 1998. The secondary role of the leftist socialists in a coalition with the right-wing political parties risked confusion for the electorate and for supporters of both sides. If in the 2004 election, the presidential candidate Oleksandr Moros supported the non-party presidential candidate Viktor Yushchenko and gave him his votes; it was his decision. In the circumstances of the parliamentary election, the socialist leader did not want to test the loyalty of his already declining electorate.

Finally, as in the 2002 election, the parties and blocs had little cohesion within them. The principle of gratitude for the supporters of the Orange team was used once again during the formation of the list of the bloc Our Ukraine. It involved the inclusion of celebrities and close allies of Yushchenko such as singer Ruslana Lyzhechko (No 5) ${ }^{81}$, popular journalist Olga Gerasymuk (No 4) and even a godmother of one of the Yushchenkos' children in the list of the bloc. ${ }^{82}$ From the 449 candidates on the list 40 candidates were running as unaffiliated. ${ }^{83}$ Yushchenko himself was absent from the list, the top place taken by Yuriy Ekhanurov, the acting prime-minister of Ukraine and former

\footnotetext{
${ }^{81}$ Ruslana Lyzhechko was the winner of the Eurovision Song Contest -2004 and campaigned for Yushchenko during the Orange revolution.

${ }^{82}$ No19 on the list was Oksana Bilosir, the Ukrainian singer and the godmother of Yushchenko's daughter.

${ }^{83}$ From the list of the candidates from the electoral block "Our Ukraine," Central Electoral Commission of Ukraine 10 June $2007<h t t p: / / w w w . c v k . g o v . u a / p l s / v n d 2006 / W 6 P 001>$.
} 
vice prime-minister under the Kuchma regime. The appearance of Anatoliy Kynakh, the leader of Party of Industrialists and Entrepreneurs and a supporter of Kuchma in the 2002 election, as second on the bloc's list in the 2006 election also was due to his support of Yushchenko in 2004. Taras Kuzio notes:

Our Ukraine-2006 is more centrist and pro-business, comprising parties such as the Party of Industrialists and Entrepreneurs, which supported Kuchma in the 2002 elections, defected to Yushchenko's camp only in the second round of the 2004 presidential election and joined Our Ukraine-2006. ${ }^{84}$

The same was true about the BYT. Mykola Tomenko, a political scientist, who was running as number 62 of the bloc "Our Ukraine" in 2002 election, was elevated to the third place on the list of the BYT in the 2006 election. The popular journalist Andriy Shevshenko, who was the leading reporter from the opposition TV Chanel 5 during Orange revolution, was placed as number five on the list of the bloc. Even though the number of parties in the bloc declined from four in the 2002 election to two in the 2006 election, the number of the unaffiliated candidates increased from six in the 2002 election to 79 in the 2006 election. ${ }^{85}$ Due to the limited space on the list of candidates, each side hoped to bring its own team by participating separately in the election.

\subsection{Conclusion}

After the analysis of the political party system in Ukraine, the character of the political parties' formation, their competition and their influence on the effectiveness of the political opposition some conclusions may be drawn.

First, the effectiveness of the parties of the future Orange team was restricted by the institutional structure which reduced their ability to compete effectively with the

\footnotetext{
84 Taras Kuzio, "Yushchenko: Constructing an Opposition," Transitions on line 11 August 2006, 14 June 2007<http://www.tol.cz.proxy.library.carleton.ca/look/TOL/printf.tpl?IdLanguage>.

${ }^{85}$ According to the list of the candidates from the electoral bloc Yulia Tymoshenko Central Electoral Commission of Ukraine 26 June $2007<$ http://www.cvk.gov.ua/pls/vd2002/webproc0e>, <http://www.cvk.gov.ua/pls/vnd2006/W6P001>.
} 
government. The institutional framework of the country in 2002 did not support the competitiveness of the opposition. The non-party character of the government in Ukraine before the 2004 constitutional reform limited the parties' influence on the political process. In contrast, the personalization of the presidential campaign in Ukraine and the non-party character of the post of the president facilitated the unity of the opposition forces in the 2004 presidential election. The Orange team was not in opposition to the program of the government or to the governing party, but to a particular individual in power. In the 2006 election, after the constitutional and electoral reform, the role and power of the opposition political parties was expected to increase; however, this did not occur.

Thus, a central factor in explaining the ineffectiveness of the political opposition is that that the members of the Orange team had different goals. If in the 2002 election the bloc Tymoshenko and the Socialist party of Ukraine chose the path of the movement, or radical type of the political opposition in their actions, Our Ukraine chose to collaborate with the government. In the 2006 election Our Ukraine was a part of the government while the BYT and the Socialist party were in opposition to the government. The different positions of the parties meant different goals that required different strategies for their achievement.

Second, the character of the parties' and blocs' support limited their effectiveness and prevented them from collaborating. Instead of mobilising passive supporters through the country and widening their electorate, the members of the Orange team preferred to campaign in the safe regions where they already had support. 
Third, the parties and blocs of the Orange team represented non-mass political parties with a top-down type of the formation around the leader. For that reason their activity and competition was built around the leader's personality rather than a well defined party program. By joining the grand coalition, individual party leaders within the Orange team would risk losing their prominence before the electorate.

Finally, the composition of the electoral party lists of the blocs during the elections suggested that the Orange team was in effect a continuation of the previous regime rather than a new alternative government. The presence of many members of the Kuchma government on the list of the bloc Our Ukraine and BYT blurred the line between the opposition and the government. For this reason the presence or absence of cooperation in the election would not likely have resulted in an effective coalition government. 


\section{CHAPTER 3 \\ CONSTITUTION OF UKRAINE AND THE EFFECTIVENESS OF THE POLITICAL OPPOSITION}

The institutional framework of a country influences the effectiveness of an opposition in both its contributions to the conduct of government, and in its ability to restrain government action. The political opposition is more effective when the institutional framework of a country provides equal conditions for all political actors to participate in the political process. A state's constitution should guarantee the rights of the minority (the opposition) to challenge the rule of majority (the government) without being suppressed.

Ukraine's institutional framework also has impact on the effectiveness of the opposition parties. In 2002 when the parties of the future Orange team were first elected to Ukraine's parliament, the Verkhovna Rada, the political system was a semipresidential regime with a mixed electoral system. ${ }^{1}$ Many analysts (Bunce, 1997; Stepan and Skach, 2001, Greenberg and Katz, 1993; Reynolds, 2001) posit that semi-presidential systems do not encourage creation of an effective political opposition because of the presence of a dual executive, the president and the parliament (and cabinet). ${ }^{2}$ In the circumstances of a president-parliamentary system the powerful president is the head of state and the head of the executive. The opposition, represented in the legislature, does not have influence on the non-party president or on the cabinet that serves at the president's pleasure. This is a valid criticism of the institutional framework surrounding

\footnotetext{
${ }^{1}$ The 2002 parliamentary election took place in accordance with mixed electoral system that existed before the changes as of July 2005. A detailed discussion of the type of the electoral system in Ukraine will be provided in Chapter 4.

${ }^{2}$ For the purpose of this study, Robert Elgie's definition of semi-presidential regime will be used. It is as follows: "A semi-presidential regime may be defined as the situation where a popularly elected fixed-term president exists alongside a prime-minister and cabinet who are responsible to parliament." See Robert Elgie, ed., Semi-Presidentialism in Europe (New York: Oxford University press, 1999)13.
} 
the 2002 election. The parties of the opposition were elected with $37.7 \%$ of the vote nation wide on the proportional representation ballot, but this did not translate into an ability to challenge and influence the government. The institutional framework did not provide the right to the parliament and consequently to the parliamentary parties, to form the cabinet. The appointment of the cabinet was prerogative of the president.

The changes to the institutional framework, approved in 2004, came into force in January 2006, three months before the next parliamentary election. They transformed the presidential-parliamentary system into a parliamentary-presidential one, involving a shift in power to the parliament from the president. The power to appoint and dismiss the cabinet was given to the Rada, where previously this had been the prerogative of the president. According to the tenets of Juan J. Linz and Arturo Valenzuela ${ }^{3}$, such strengthening of parliament should expand the power and the influence of political parties and the opposition, thereby helping to consolidate democracy.

In Ukraine's case this did not occur. In the first parliamentary election after the constitutional changes, the Orange team failed to form a parliamentary coalition to govern, despite having the most seats collectively. As a result, the Party of Regions, headed by failed presidential candidate, Viktor Yanukovich, formed the parliamentary coalition and government with the Socialist party and the Communist party. The institutional framework, as it existed prior to 2006, did not provide support or foster cooperation between the likeminded Orange parties.

This chapter will analyze the institutional framework of Ukraine and its influence on the effectiveness of the political opposition in order to answer the main research

\footnotetext{
${ }^{3}$ Juan J. Linz, Arturo Valenzuela, The Failure of Presidential Democracy (Baltimore: The Johns Hopkins UP, 1994).
} 
question: why did the parties of the Orange team fail to create a coalition government after the Orange revolution and the 2006 election? The set of variables to be reviewed are: the constitutional power of the legislature; the constitutional power of the executive; and the "system of appointing or removing the government."

The chapter concludes that the institutional framework of Ukraine before and after the constitutional reform 2004 did not promote an effective political opposition. The changes from a presidential-parliamentary to a parliamentary-presidential system in 2004 did not solve the problem of the dual executive in Ukraine between the president and the cabinet. The president's interference in the system of the appointing of cabinet after the reform caused conflict within the government. Meanwhile, the constitutional power of the legislature and the law on the rules of procedure of the Rada restricted the rights of the political opposition to participate in the political process. An absence of constitutional regulation of the relations between the parliamentary coalition and the opposition, the complicated system of the cabinet appointment and dismissal, coupled with weak collaboration between the president and the parliamentary minority did not provide supportive conditions for the development of an effective political opposition even after the 2004 reforms came into force.

\subsection{Overview of the Constitution of Ukraine since Independence}

The change from an imposed legal and constitutional Soviet republic to a legitimate sovereign and independent Ukrainian state required political and legal transformation. After the collapse of the Soviet Union, Ukraine declared its sovereignty

\footnotetext{
${ }^{4}$ Ionescu 13.
} 
in July $1990^{5}$ and proclaimed the country's independence in August $1991^{6}$. The constitution of Ukraine was passed in June of 1996, almost six years after the declaration of the country's sovereignty. The 1996 Constitution of Ukraine defined Ukraine as a unitary state (Ch.1, Art.2) with a presidential-parliamentary system of governing, with a separation of power between the legislative, executive and judicial branches. ${ }^{7}$

As with many post-Soviet republics Ukraine adopted a mixed political regime rather than a Western model of clear parliamentarism. ${ }^{8}$ The collapse of the Soviet Union plunged Ukraine into a situation of emergency; the newly independent republic was not ready for such dramatic changes including the introduction of a new state, a new political system and most importantly a new constitution. Semi-presidentialism was the safe choice for the political elite in the circumstances of sudden top-down independence and a lack of knowledge. The combination of a directly elected president and the elected parliament was to be the guarantee of a power balance between the executive branch and legislature.

In virtually all of the republics of the former Soviet Union, the 1991 disintegration of state socialism and the Soviet Union led to the adoption of governments where presidents were given important powers, and this can be explained by the fact that independence in many cases came suddenly and that the one model of government easily and quickly emulated was the presidential model developed by Gorbachev. ${ }^{9}$

\footnotetext{
5 Deklaratsiya pro Derzhavnyy Suverenitet Ukrainy (Declaration of State Sovereignty of Ukraine) no 31, dated 16 July 1990, 20 January $2007<$ http ://zakon1.rada.gov.ua/cgibin/laws/main.cgi?nreg=55\%2D12\&p=1172763330653063>.

${ }^{6}$ Postanova Verkhovnoyi Rady Ukrainskoyi RSR pro Progoloshennya Nezalezhnosti Ukrainy (Act of the Declaration of Independence of Ukraine) no 38, dated 24 August 1991, 20 January 2007 $<$ http://zakon1.rada.gov.ua/cgi-bin/laws/main.cgi?nreg=1427\%2D12\&p=1172763330653063>.

${ }^{7}$ Konstytutsiya Ukrainy (Constitution of Ukraine), Ch. I, art. 6 (Kyiv: Prosvita, 1996).

${ }^{8}$ Clear parliamentarism refers to the Western European model of the parliamentary democracy with the parliament as the only elected political body and the prime-minister and the cabinet that is appointed by the parliament (parliamentary coalition) and is responsible to the parliament.

${ }^{9}$ Valerie Bunce, "Presidents and the transition in Eastern Europe," Presidential Institutions and Democratic Politics. Comparating Regional and National Contexts, ed. Kurt Von Mettenheim (Baltimore: The Johns Hopkins UP, 1997) 168.
} 
Moreover, for the newly established Ukrainian political elite that consisted mostly of the ex-communist apparatchiks ${ }^{10}$, the presence of the post of the president was viewed as the guarantee of Ukraine's sovereignty and independence from the Russia. "It was therefore not originally envisaged that the new Ukrainian president would act as a head of state; his function would be to protect Ukrainian law and institutions from Moscow's interference."11

Semi-presidentialism generally and the presidential-parliamentarianism specifically are not conductive to supporting an opposition function. ${ }^{12}$ This is due to the system of the dual executive and the combination of the elected president and the elected legislature. In these conditions the political minority has less influence on the work of the government. The president has authority to appoint and dismiss the cabinet without the influence of the parliament and thus the political parties; this in turn limits the political opposition's access to power. The cabinet's dependence on the authority of the non-party president rather than on the parliament does not provide for party alternation in power as occurs in parliamentary regimes.

\footnotetext{
${ }^{10}$ The republican election to the Supreme Council in March 1990 resulted in the parliament that consisted mostly from the members of the Communist party of Ukraine, see Kataryna Wolczuk, The Moulding of Ukraine: the Constitutional Politics and State Formation (Budapest: Central European UP, 2001) 67. ${ }^{11}$ Andrew Wilson, "Ukraine" Semi-Presidentialism in Europe, ed. Robert Elgie (New York: Oxford UP, 1999) 261.

${ }^{12}$ According to Robert Dahl, the most favorable political regime for the political opposition is the polyarchy, which author defines as a regime that "... [I]mposes the fewest restraints on the expression, organization, and representation of political preferences and on the opportunities available to opponents of government. Most individuals are effectively protected in their right to express, privately or publicly, their opposition to the government, to organize, to form parties and to compete in elections where voting is secret, unintimidated, and honestly counted and where the results of elections are binding according to well-established rules." Robert A. Dahl, ed., Regimes and Opposition (New Haven: Yale UP, 1973) 3.
} 


\subsection{The Constitution during the 2002 Parliamentary Election}

\subsubsection{The power of the parliament}

By virtue of the Law on the Elections of the Peoples' Deputies of Ukraine (electoral law of 2001) ${ }^{13}$ the 2002 parliamentary election took place within a mixed electoral system. Half of the seats (225) were elected in the single-member majority districts. The other half were allotted based upon the percentage of vote received by each party, bloc nation wide from proportional representation party list with a $4 \%$ threshold. The work of the parliament was regulated by the Constitution of Ukraine of 1996 (constitution of 1996), the Law on the Rules of Procedure of the Verkhovna Rada of Ukraine (Reglament 2002) ${ }^{14}$ and the Law on the status of Peoples' Deputies of Ukraine. ${ }^{15}$

In the 2002 parliamentary election, as Table 3.1 shows, Our Ukraine won the largest percentage of votes from the proportional representation ballot, $23.6 \%$ for 70 seats. In combination with the BYT (Bloc Yulia Tymoshenko), which took fourth place with $7.2 \%$ for 22 seats and the Socialist party of Ukraine, $6.9 \%$ for 24 seats, the political opposition had $37.7 \%$ of votes from the proportional representation party list. However, they were not able to create a parliamentary coalition on their own due to the institutional structure that did not define the party-based principle for coalition formation. This benefited the pro-Kuchma bloc "For United Ukraine", which won the biggest number of seats in SMD, 66 of the total of 225 seats. Together with a majority of 93 unaffiliated

\footnotetext{
${ }^{13}$ Zakon Ukrainy pro vybory narodnykh deputativ Ukrainy (Law of Ukraine on the Election of Peoples Deputies of Ukraine) no. 2766-III, dated 18 October 2001 (VVR, 2001, No51-52, art.265) <http://zakon1.rada.gov.ua/cgi-bin/laws/main.cgi?nreg=2766\%2D14\&p=1185383754148193>.

${ }^{14}$ Zakon Ukrainy Pro Reglament Verkhovnoyi Rady Ukrainy (The Law on the Rules of Procedure of the Verkhovna Rada of Ukraine) no 129, dated 27 July1994, 10 October 2006<http://zakon1.rada.gov.ua/cgibin/laws/main.cgi?page=2\&nreg=129\%E0\%2F94\%2D\%E2\%F0>.

${ }^{15}$ Zakon Ukrainy Pro Status Narodnogo Deputata Ukrainy (The Law of Ukraine on the Status of the Peoples' Deputies of Ukraine) no. 2790-XII, dated 17 November 1992, 10 October 2006 <http://zakon1.rada.gov.ua/cgi-bin/laws/main.cgi?nreg=2790-12>.
} 
candidates, and the Kuchma loyalist Social Democratic party (United), the bloc "For

United Ukraine" was able to create a parliamentary coalition passing over the political

opposition. ${ }^{16}$ "In 2002, the opposition actually won the parliamentary elections but failed

to create a government, ceding the initiative to the more skillful and crafty pro-

presidential forces."17

Table 3.1 Results of the 2002 Parliamentary Election

\begin{tabular}{|l|l|l|l|l|}
\hline Political parties and blocs & $\begin{array}{l}\% \text { of } \\
\text { votes }\end{array}$ & $\begin{array}{l}\text { Number of seats } \\
\text { (PR) }\end{array}$ & $\begin{array}{l}\text { Number of } \\
\text { seats (SMD) }\end{array}$ & $\begin{array}{l}\text { Total number } \\
\text { of seats }\end{array}$ \\
\hline Bloc Viktor Yushchenko "Our Ukraine" & 23.57 & 70 & 40 & 110 \\
\hline Communist Party of Ukraine & 19.98 & 59 & 7 & 66 \\
\hline Bloc "For a United Ukraine" & 11.77 & 35 & 66 & 101 \\
\hline Yulia Tymoshenko bloc & 7.26 & 22 & & 22 \\
\hline Socialist Party of Ukraine & 6.87 & 20 & 2 & 22 \\
\hline SDPUu & 6.27 & 19 & 5 & 24 \\
\hline Unaffiliated candidates & & & 93 & 93 \\
\hline Bloc "Unity" & 1.09 & & 4 & 4 \\
\hline $\begin{array}{l}\text { "Democratic party of Ukraine - Party } \\
\text { Democratic Union" }\end{array}$ & 0.87 & & 3 & 3 \\
\hline Party of National- Economic Development & & & 1 & 1 \\
\hline Ukrainian Sea Party & 0.11 & & 1 & 1 \\
\hline TOTAL & & 225 & 222 & 447 \\
\hline
\end{tabular}

Source: table produced by author based on data from the Central Electoral Commission of Ukraine, 26 January $2007<$ http://www.cvk.gov.ua/pls/vd2002/webproc0v>.

The Reglament 2002 also allowed for the formation of parliamentary factions on the basis of individual membership rather than on a party basis. "The Peoples Deputies factions in the Verkhovna Rada are formed exclusively by the deputies on the conditions that each parliamentary faction consists at least of the 14 people's deputies of Ukraine." 18 The absence of the regulation in the constitution and the Reglament 2002 on the formation of factions resulted in high volatility, which benefited the parties loyal to

${ }_{16}^{16}$ Central Electoral Commission of Ukraine $<$ http://www.cvk.gov.ua/pls/vd2002/webproc0v>.

${ }_{17}^{17}$ Mykola Riabchuk, "Learning democracy: The Internal Political Development of Ukraine since 1991," The Ukrainian Quarterly LXII. 2 (Summer 2006): 217-221.

${ }^{18}$ Reglament, Ch. IV, art.4.2.1, sec. 1. 
President Kuchma. Reportedly, they pursued the deputies of opposition factions with offers of personal benefits. ${ }^{19}$

Figure 3.1 shows the changes in the size of the factions and their instability after the 2002 election. ${ }^{20}$ From the first session of the parliament that started on the May, 14, 2002 to the beginning of $9^{\text {th }}$ session on the February 7, 2006, the number of factions and their composition was changing constantly. The pro-Kuchma "United Ukraine" had 175 members in the beginning of the first session of the parliament in May 2002. By the beginning of the $7^{\text {th }}$ session in February 2005 after the 2004 presidential election the faction declined to the size of the 22 members. Comparatively, the faction "Party of Regions" was formed only during the second session in Rada in September 2002 with 36 members prior to the appointment of Viktor Yanukovich as the prime-minister on November 21, 2002. The Party of Regions reached its peak, 67 deputies, during the $5^{\text {th }}$ and $6^{\text {th }}$ sessions between February and September of 2004 priori to the presidential election that year. The composition of the opposition factions also changed due to the absence of regulation of the party-based formation of factions. The faction of Our Ukraine decreased from 119 deputies in 2002 to 44 before the 2006 parliamentary election. By comparison, the faction of Yulia Tymoshenko increased after the dismissal of her cabinet in July 2005 from the 23 members first elected in 2002 to 39 members in September 2005. The number of independent deputies also varied from 13 in the beginning of the $1^{\text {st }}$ session (May 2002) to 37 in the beginning of the $8^{\text {th }}$ session (September 2005).

\footnotetext{
${ }^{19}$ Sarah Whitmore, "Faction institutionalization and parliamentary development in Ukraine," Journal of Communist Studies and Transition Politics 19.4 (2003):41-64, 61.

${ }^{20}$ The official web-site of the Verkhovna Rada of Ukraine $-4^{\text {th }}$ convocation, 06 February 2007 <http://gska2.rada.gov.ua:7777/pls/radac/h_index_arh?nom_skl=4>.
} 


\section{Figure 3.1}

\section{Parliamentary Factions in the Rada, 2002-2006}

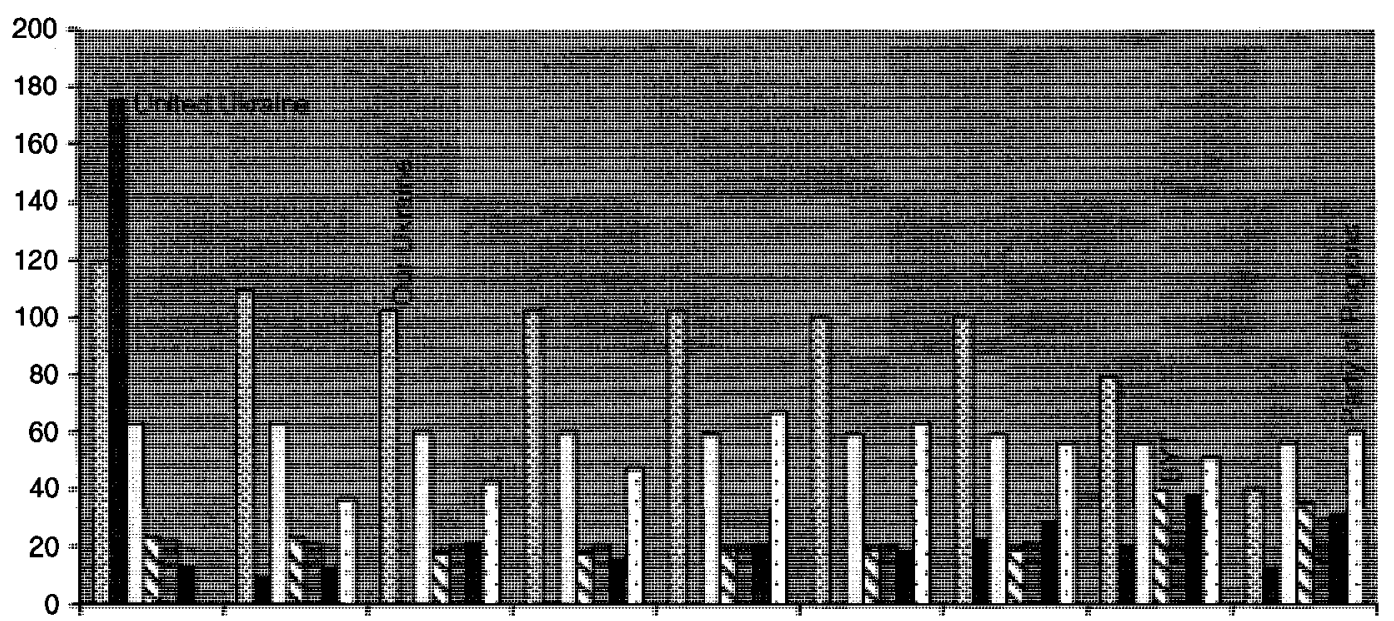

1st session-15.05.02 3rd session-04.02.03 5th session-03.02.04 7th session-01.02.05 9th session- 07.02.06

\begin{tabular}{|c|c|c|}
\hline $\begin{array}{l}\text { OOur Ukraine } \\
\text { QBYT } \\
\text { 口 Party of Regions }\end{array}$ & $\begin{array}{l}\text { Enited Ukraine } \\
\text { Socialist Party of Ukraine }\end{array}$ & $\begin{array}{l}\text { DCommunist Party of Ukraine } \\
\text { Unfactional }\end{array}$ \\
\hline
\end{tabular}

Source: graph produced by author based on the composition of the factions in the Verkhovna Rada of Ukraine, IV convocation, Verkhovna Rada of Ukraine 22 January 2007

$<\mathrm{http}: / /$ gska2.rada.gov.ua/pls/radac_gs09/h_index_arh?nom_skl=4>.

Vote of non-confidence. A parliamentary political opposition can be effective if it has the power to vote non-confidence in the cabinet. However this power could not be

effectively exercised in Ukraine after the 2002 election. According to the Ch. IV, Art.87 of the Constitution of Ukraine (earlier text)

Verkhovna Rada of Ukraine on the proposal of the $1 / 3$ of the people deputies from the Constitutional composition of parliament may view the question about the cabinet responsibility and adopt the resolution of no confidence in the cabinet by the majority of the constitutional composition of Verkhovna Rada. ${ }^{21}$

The constitutional right of the Rada to initiate a vote of non-confidence has been exercised only twice, ${ }^{22}$ because notwithstanding the vote, the president can continue with his cabinet. "The Cabinet of Ministers of Ukraine, whose resignation was accepted by the

${ }^{21}$ Constitution of Ukraine, Ch.IV, art. 87, sec. 1.

${ }^{22}$ Among all of the prime-ministers and cabinets that have existed since independence, only two received a vote of non confidence from parliament - Viktor Yushchenko in 2001 and Viktor Yanukovich in 2004. 
President of Ukraine, continues to work on the instructions of the President of Ukraine but not longer than 60 days."23

This power of the president disadvantaged the political opposition in the Rada. On December $1,2004^{24}$, the parliamentary political opposition initiated a vote of nonconfidence in the cabinet of Prime-Minister Viktor Yanukovich. The Rada voted for the dismissal of the cabinet ${ }^{25}$, but former president Kuchma refused to sign the decree and accept Yanukovich's resignation. Only on December 7, 2004, after Yanukovich had submitted his resignation, did Kuchma comply with his request.

The constitution also limited the frequency with which the Rada could initiate a vote of non-confidence in the cabinet. "The issue of responsibility of the cabinet of ministers of Ukraine shall not be considered by the Verkhovna Rada of Ukraine more than once during one regular session, and also within one year after the approval of the program of activity of the cabinet of ministers of Ukraine." 26 Thus, the parties of the political opposition were limited in their influence on government activity. Moreover, the government did not have any control over its activity; this led to a government that was unaccountable and non-responsive to the parliament.

\subsubsection{The power of the president}

According to the constitution of 1996 the president was the head of state and the de-facto head of the executive. ${ }^{27}$ The president is

\footnotetext{
${ }^{23}$ Constitution of Ukraine, Ch. VI, art. 115, sec. 5.

24 The vote of the non-confidence took place during the 2004 presidential election when Yanukovich combined to serve as prime-minister, while being an active candidate for the presidency.

${ }^{25}$ According to record of the session of the Rada, 234 deputies voted for the dismissal of the Yanukovich cabinet. Verkhovna Rada 22 January 2007<http://zakon 1.rada.gov.ua/cgi-bin/laws/main.cgi?nreg=2215$15>$.

${ }^{26}$ Constitution of Ukraine, Ch. IV, art. 87, sec. 2.

${ }^{27}$ According to Constitution 1996 the cabinet is the head of executive, although the president had the power to appoint and dismisses the prime-minister and cabinet with a parliament's agreement.
} 
... [T] he guarantor of the state sovereignty, territorial integrity of Ukraine, adherence to the Constitution of Ukraine, human and civil rights and freedoms. The president is elected by Ukrainian citizens once in five years by secret ballot on the basis of universal, equal and direct suffrage. ${ }^{28}$

Even though the constitution adopted the presidential-parliamentary system of governing, the constitutional power of the president of Ukraine was equal to the power of the president within a presidentialism system. ${ }^{29}$ According to the constitution of 1996 (Ch. $\mathrm{V}$, Art.103); the president is directly elected for a fixed term; the president has rights of legislative initiative (Ch. IV, Art.93, Section 1), rights to dissolve the legislature on the condition that "the plenary sessions of Verkhovna Rada did not start during 30 days since the beginning of the session" (Ch. IV, Art.90, Section 2 and Ch. V, Art.106, Section 8); the power to appoint and dismiss the cabinet (Ch. V, Art.106, Section 9) and the power of veto of legislation (Ch. V, Art.106, Section 30). The constitution (Ch. V, Art.106, Section 10) endowed the president rights to appoint and dismiss the heads of oblast governments that undermined the principle of the decentralisation of power and led to the centralisation of power in the presidency. The president's monopoly over the executive limited the power of the Rada and because of this the political opposition had minimal control over the work of the government.

\subsubsection{The system of appointing and removing the government}

Under the terms of the constitution the cabinet was the head of the executive. In practice the president was the head of state and the head of the executive. This led to a high degree of instability within the government. During the administration of two presidents, Leonid Kravchuk, December 1991 to October 1994 and Leonid Kuchma,

\footnotetext{
${ }^{28}$ Constitution of Ukraine, Ch.V, art.102, 103, sec. 1.

${ }^{29}$ Arend Lijphart defined three main characteristics that are typical for presidentialism: the president is the head of the state and the head of the government; the president is popularly elected; the presence of the non-collective, one-person executive. See Arend Lijphart, Pattern of Democracy, Governments Forms and Performance in thirty-six countries (New Haven: Yale UP, 1999) 117-118.
} 
October 1994 to January 2005, there were 12 prime-ministers and cabinets. In this 15 year period of post-independence the average length of service for a prime-minister was 14 months, the longest serving was two and a half years. ${ }^{30}$ As the constitution (Ch. IV, Art. 77, Ch. V, Art. 103, Section 4) separates the timing of the presidential and parliamentary elections, and since both are elected for fixed terms, each presidential election led to a new cabinet, appointed by the winner of the presidential elections.

The replacement of the cabinet was the way of finding a compromise between the legislature and the president. "Because presidents do not normally enjoy a majority in the legislature, they resort to rapid ministerial rotation as a device in their perpetual search for support on key issues." ${ }^{\text {31 }}$ Furthermore, the non-party character of the post of the prime-minister and the cabinet promoted the links of "technocrat cabinets" 32 that were not responsive to the public.

The post of the prime-minister was not originally considered to be an influential political position; rather it was viewed as a position that provided public recognition. "What it does, however, is immediately to promote its holders to a position of national recognition and provide them with some substantial powers over the state apparatus." ${ }^{33}$ The post of the prime-minister was viewed as a starting point for a future presidency. Two of the three presidents of independent Ukraine, as Table 3.2 shows, Leonid Kuchma

\footnotetext{
${ }^{30}$ Valeriy Pustovoytenko who was the prime-minister under Leonid Kuchma, served for 2.5 years from July 1997 to December 1999. Official site of the Cabinet of ministers of Ukraine, 06 February 2007 <http://www.kmu.gov.ua/control/uk/publish/article?\&art_id=1266975\&cat_id=661266>.

${ }^{31}$ Stepan, Alfred, Scach Cindy, "Constitutional frameworks and democratic Consolidation: Parliamentarism versus Presidentialism," Arguing Comparative Politics, ed. Alfred Stepan (New York: Oxford UP, 2001) 275.

${ }^{32}$ Oleg Protsyk defined a technocrat cabinet as follows: "A cabinet is defined technocratic when a primeminister and majority of cabinet members do not have formal party affiliation. Policy expertise and government experience rather than party ties are usually cited as the criteria employed to select candidates for ministerial positions in technocratic cabinets." See Oleg Protsyk, "Intra-executive Competition between President and Prime-minister: Patterns of Institutional Conflict and Cooperation under SemiPresidentialism," Political Studies 54 (2006):242.

${ }^{33}$ Ibid., 231.
} 
and Viktor Yushchenko, were the prime-ministers in the cabinet of the outgoing

president. Both were dismissed from the cabinet and became the candidate of the

opposition during the presidential campaign. ${ }^{34}$

Table 3.2 Prime-Ministers of Ukraine, Presidential Candidates

\begin{tabular}{|l|l|l|}
\hline President & Prime-Minister (Presidential candidate) & $\begin{array}{l}\text { Winners (losing candidates) in } \\
\text { the elections }\end{array}$ \\
\hline $\begin{array}{l}\text { Leonid Kravchuk } \\
(1991-1994)\end{array}$ & Leonid Kuchma (13 October 1992 - 22 September 1993) & $\begin{array}{l}\text { 1999-Leonid Kuchma } \\
\text { (Leonid Kravchuk lost) }\end{array}$ \\
\hline $\begin{array}{l}\text { Leonid Kuchma } \\
1994-2005\end{array}$ & $\begin{array}{l}\text { Viktor Yushchenko (22 December 1999 - 29 May 2001) } \\
\text { Viktor Yanukovych (21 November 2002 - 5 January 2005) (1st time) }\end{array}$ & $\begin{array}{l}\text { 2004 - Viktor Yushchenko } \\
\text { (Viktor Yanukovich lost) }\end{array}$ \\
\hline $\begin{array}{l}\text { Viktor Yushchenko } \\
\text { 2005-present }\end{array}$ & $\begin{array}{l}\text { Yulia Tymoshenko (January2005-September 2005) } \\
\text { Yuriy Yekhanurov (September 2005-August 2006) } \\
\text { Viktor Yanukovich ( August 2006- present) }\end{array}$ & 2010-? \\
\hline
\end{tabular}

Source: table produced by author based on information from the Official site of the Cabinet of Ministers of Ukraine, 15 January 2007

$<$ http://www.kmu.gov.ua/control/uk/publish/article?\&art_id=1266975\&cat_id=661266>.

\subsection{The 2004 Presidential Election}

The presidential election of 2004 and the Orange revolution that followed saw the success of the political opposition and its candidate, Viktor Yushchenko. Despite the government efforts to falsify the results of the election in favour of its candidate Viktor Yanukovich $^{35}$, the political opposition succeeded in ousting the regime of the Kuchma, and Viktor Yushchenko ultimately emerged as the President of Ukraine.

Due to neglect of the electoral law by the government $\operatorname{side}^{36}$, the Orange team changed the nature of its opposition from the fundamental to the pressure group type of

\footnotetext{
${ }^{34}$ If Viktor Yanukovich and Yulia Tymoshenko run for the office of the president in 2010, they would continue the pattern of the dismissed prime-minister being elected to the post of the president.

${ }^{35}$ After the second round of the 2004 Presidential election, the Central Election Commission declared the pro-government candidate Viktor Yanukovich the winner and the elected President of Ukraine despite the results of the exit-polls that showed the opposition candidate Viktor Yushchenko the winner of the elections. See "Yushchenko won $11 \%$ more than Yanukovich. Final results of exit-poll." Ukrayinska Pravda 21 November 2004, 15 January 2007 <http://www.pravda.com.ua/news/2004/11/21/13935.htm>.

${ }^{36}$ One of the biggest problems during the 2004 presidential elections was the system of absentee certificates that allowed the voters to vote in places and locations different than his or her residency. As a result the supporters of Yanukovich voted in a numbers of locations thus increasing the real number of votes for the Candidates. According to the report by OSCE, $5 \%$ of voters were added to the voting list using the system of absentee certificates. See "Ukraine Presidential election", 31 Oct, 21 Nov and 26 Dec 2004, OSCE 15 January 2007<http://www.osce.org/documents/odihr/2005/05/14224_en.pdf>.
} 
the political opposition. ${ }^{37}$ Even though this type of the political opposition is not fully institutionalized and acts through strikes, mass actions, protest or revolution, in the case of Ukraine it was peaceful and effective. The pressure from the opposition supporters and international recognition of the electoral fraud ${ }^{38}$ resulted in a re-vote of the second round of the election on December 26, 2004. Viktor Yushchenko became the president of Ukraine on January 23, 2005.

However the Orange team became a victim of the old institutional framework.

First, the power of the president to appoint the cabinet disadvantaged the collaboration between the office of the President Yushchenko, the Rada and the Cabinet of Yulia Tymoshenko. As a result during the first year of his presidency, Viktor Yushchenko appointed two prime-ministers. The dismissal of the Cabinet of Tymoshenko happened without the interference of the Rada but by the decree of the president. ${ }^{39}$ Thus, the unity of the political opposition during the revolution did not translate in to a united government.

Second, even though the Rada had less constitutional power than the president, the Orange team was in a minority in the Rada. Most parties elected in 2002 remained loyal to Kuchma. Thus, the pro-Kuchma parliamentary majority limited the ability of the parties of the political opposition in their attempt to implement the program of President Yushchenko.

\footnotetext{
${ }^{37}$ Leonard Shapiro, Introduction, Political Opposition in One-party States, ed. Leonard Shapiro (London: The Macmillan Press Ltd, 1972) 7.

${ }^{38}$ According to a report by the OSCE, the second round of the presidential election was recognized as unfair. See "Ukraine Presidential election", 31 Oct, 21 Nov and 26 Dec 2004, OSCE 15 January 2007<http://www.osce.org/documents/odihr/2005/05/14224_en.pdf>.

${ }^{39}$ Ukaz Presydenta Ukrainy Pro Prypynennya Povnovazhen Prem'yer-ministra Yuliyi Tymoshenko ta vidstavku Kabinetu Monistriv Ukrainy (A decree of the President of Ukraine on the dismissal of the PrimeMinister Yulia Tymoshemko and the Cabinet of Ministers of Ukraine) no. 1234/2005, dated 08 September 2005, 01 March 2007 <http://zakon1.rada.gov.ua/cgi-bin/laws/main.cgi?nreg=1234\%2F2005>.
} 
Finally, a constitutional reform was adopted as a compromise ${ }^{40}$ between the political opposition and President Kuchma during the 2004 election, would become law in 2006. It limited the term of the new government to a little over one year before the parliamentary election in early 2006.

\subsection{The Constitution during the 2006 Parliamentary Election}

With constitutional reform in 2004, which would come into force in 2006 , Ukraine adopted a parliamentary-presidential system. ${ }^{41}$ As was mentioned earlier the parliamentarism is considered a more effective political system for the consolidation of democracy in transition countries than presidentialism. A government that is formed by elected political parties is likely to be more accountable to the parliament than a nonparty government that is appointed by a non-party constitutionally powerful pesident. By voting for the political parties in the election, the citizens choose the government and its program.

In a parliamentary system, the prime-minister has to maintain support in assembly or lose her position. For this reason a parliamentary government is far less likely to succumb to immobilism due to a lame duck executive. For this same reason it is less likely to fall victim to weak support in the assembly for extended periods, as it is claimed often happens in presidential systems. ${ }^{42}$

\subsubsection{The power of the parliament}

The 2004 reform endowed the parliament with rights to appoint the primeminister and the cabinet.

\footnotetext{
${ }^{40}$ The opposition insisted on a re-vote of the second round and changes to the law on the election of the president of Ukraine. The former President Kuchma opposed the revote of the second round and insisted on the new election. The vote of the bill that included the changes to the law on the election of the president of Ukraine together with constitutional reform was a compromise between the two sides. ${ }^{41}$ Zakon Ukrainy Pro Vnesennya Zmin do Konstytutsii Ukrainy (Law of Ukraine on the changes to Constitution of Ukraine) no 2222-IV, dated 08 December 2004, 01 March 2007

<http://zakon1.rada.gov.ua/cgi-bin/laws/main.cgi?nreg=2222-15>.

${ }^{42}$ Timothy Frye, "Presidents, Parliaments, and Democracy: Insights from the Post-Communist World," The Architecture of Democracy: Constitutional Design, Conflict Management, and Democracy, ed. Andrew Reynolds (New York: Oxford UP, 2002) 84.
} 
The coalition of deputies' factions in the Verkhovna Rada of Ukraine in accordance with Constitution of Ukraine submits a proposal to the President of the candidacy of the Primeminister of Ukraine and the candidacies of the members of Cabinet of Ministers of Ukraine. ${ }^{43}$

For the first time since Ukraine's independence, the cabinet was formed on the basis of the parliamentary coalition and was responsible to the parliament. ${ }^{44}$ The constitutional reform of 2004 also introduced the term "parliamentary coalition" and its role.

In the Verkhovna Rada of Ukraine according to the results of national election and in agreement with political positions the coalition of deputies factions is created, that includes the majority of national deputies of Ukraine from the constitutional composition of Verkhovna Rada of Ukraine. $^{45}$

The largest deputies' faction in parliament, which consists of the majority of the deputies from the constitutional composition of the Rada has the right to be called the parliamentary coalition (Ch.IV, Art.83, Section 10). The role of the parliamentary coalition, its rights and responsibility were regulated by Reglament (Reglament 2006). ${ }^{46}$

The Reglament 2006 defines the parliamentary coalition as a

... [V]oluntary organisation of deputies' factions, which is formed in the Verkhovna Rada in accordance with the results of elections and on the base of the political agreement. The composition of the coalition consists of the majority of people's deputies from the constitutional composition of Verkhovna Rada. ${ }^{47}$

The time limit for the formation of a coalition is specified as 30 days from the first day of the first parliamentary session of the newly elected parliament. ${ }^{48}$ The newly formed parliamentary coalition signs the agreement of the coalition of deputies' factions in which the coalition fixes its political platform and the main principles of its activity. ${ }^{49}$ The 2006 Rada election was the first election to take place after the constitutional reform

${ }^{43}$ Constitution of Ukraine, Ch. IV, art.83, sec. 8.

${ }^{44}$ Ibid., Ch IV, art.85, sec. 12.

${ }^{45}$ Ibid., Ch. IV, art.83.

${ }^{46}$ Zakon Ukrainy Pro Reglament Verkhovnoyi Rady Ukrainy (Law on the Rules of Procedure of the Verkhovna Rada of Ukraine) no 3547-XV dated 16 March 2006, 02 March 2007

$<$ http://zakon1.rada.gov.ua/cgi-bin/laws/main.cgi?nreg>.

${ }^{47}$ Ibid., Ch.XII, art.61, sec. 1.

${ }^{48}$ Ibid., Ch.XII, art.61, sec. 2.

${ }^{49}$ Ibid., Ch.XII, art.61, sec. 3, 4. 
in 2004, the new introduction of the electoral law ${ }^{50}$ and under the presidency of Viktor Yushchenko. Most often a system of proportional representation in a multi-party political context results in a parliamentary majority that is based not on one political party but on groups of political parties. The same is true in regards to the political opposition. Due to the multi-party composition of parliament, the parties of the political opposition cooperate in order to form the united parliamentary opposition.

Neither the pro-Yushchenko bloc Our Ukraine nor the Yanukovich bloc Party of Regions won a majority in the election. The Party of Regions took first place with $32.14 \%$ of the votes. The BYT took second place with $22.29 \%$, Our Ukraine took third place with $13.95 \%$ of the votes and the Socialist party took fourth place with $5.69 \%$ of votes for 33 seats. ${ }^{51}$ The parties of Orange team had sufficient deputies, 243 , for a parliamentary majority, which required 226 . However, the Orange team failed to create a parliamentary coalition and government due to a disagreement between its leaders over the key posts in the government and in parliament. “... [A] Fundamental part of changing relationships of domination depends on the opposition not only presenting itself as democratic, but also preparing itself for democratic contestation. It must be ready for democratic governance, or to form the loyal opposition." 52

In the case of Ukraine none of the members of the Orange team were prepared to compromise and share power with each other. As a result, the process of negotiations between all political factions ended in the coalition of the Party of Regions, the Socialist

\footnotetext{
${ }^{50}$ The 2006 parliamentary elections took place under the proportional representation electoral system in accordance with Law of Ukraine from 25.03.2004 № 1665-IV on the elections of People’s Deputies of Ukraine.

${ }^{51}$ According to the Official site of the Central Electoral Commission of Ukraine.

${ }^{52}$ Alfred Stepan, "Democratic Opposition and Democratic Theory," Arguing Comparative Politics, ed. Alfred Stepan (New York: Oxford UP, 2001)172.
} 
party and the Communist party which signed the Agreement of the anti-crisis coalition ${ }^{53}$ on July 7, 2006 after the Orange coalition's agreement collapsed. ${ }^{54}$ In the agreement the newly formed parliamentary coalition established its status, conditions of formation and system of interactions with the president and the cabinet (Part II, Ch.4, 5) but not its relations with the political opposition. ${ }^{55}$

Neither the constitution of 2004, nor the Reglament 2006 mentioned or defined the political opposition and its role. The Reglament defined the term "parliamentary coalition", the principles of its formation, rights and role, but it did not cover the role of the political opposition and the relations between the parliamentary coalition and parliamentary opposition. ${ }^{56}$

The term "political opposition" was introduced in the bill on the parliamentary opposition $^{57}$ by Yulia Tymoshenko in September of $2006 .{ }^{58}$ The political opposition was defined as the

political parties (blocs) of the Verkhovna Rada of Ukraine that did not join the political coalition and disagree with the political, social and economic policies of the parliamentary majority(coalition), or political, socio-economic policies of the Cabinet of Ukraine, that is formed by coalition. The political opposition prepared an alternative program (concept) of development. ${ }^{59}$

\footnotetext{
${ }^{53}$ Ugoda pro Stvorennya Antykryzovoyi Koalitsii u Verkhovniy Radi V sklykannya. (The Agreement of the Creation of Anti-crisis Coalition in the Verhkovna Rada of Ukraine between the factions of Party of Regions, faction of Socialist Party of Ukraine and faction of Communist Party of Ukraine), no 0005001-06, 09 September 2006<http://zakon1.rada.gov.ua/cgibin/laws/main.cgi?nreg=n0005001\%2D06\&p=1175798876208401>.

${ }^{54}$ The Orange team singed the Agreement of the creation the coalition on June 21 2006, Ukrayinska Pravda 10 October $2006<$ http://www2.pravda.com.ua/_site/htm1/Ugoda.doc $>$.

${ }^{55}$ The Agreement of the parliamentary coalition that was signed by the Orange team had the subject of a chapter IX covering the relations between the parliamentary coalition and parliamentary opposition.

${ }^{56}$ Reglament, Ch. 12, art. 61-67.

${ }^{57}$ Proect Zakonu Verkhovnoy Rady pro parlamentsyku opozytsiyu (Bill on the Parliamentary Opposition) dated 4 September 2006, Verkhovna Rada 8 September 2006

< http://www.rada.gov.ua:8080/pls/zweb/webproc4_1?id=\&pf3511=27810>.

${ }^{58}$ The bill was introduced after the failure of the Orange team to create a parliamentary coalition. As a result the Yanukovich party "Party of Regions" created the parliamentary coalition with the Communist Party and the Socialist party and the Orange team fell into the category of the political opposition to the coalition.

${ }^{59}$ Bill on the parliamentary opposition, Ch.I, art.1, sec. 2 .
} 
As was expected the bill did not receive enough votes to become a law in the Rada which was controlled by the pro-Yanukovich coalition. ${ }^{60}$ Furthermore, the rights and authority of the political opposition in the bill were too significant to call the political opposition a minority in any conventional sense. Chapter III, art.15 of the bill defined the rights of the political opposition as follows:

participate in the work of the Cabinet of Ministers of Ukraine by taking part in all meetings, working groups, consulting committees that are organized by the Cabinet of Minister of Ukraine, President of Ukraine; participate in the discussion of future actions and decisions of the executive and give them critical evaluation. ${ }^{61}$

The political opposition should have the right to criticize the policy of government and to provide an alternative through its work in the parliament, but not by being part of the cabinet. The Orange team was not prepared to be in the opposition after the 2006 election and as result they did not consider the rights and role required of the political opposition.

Vote of non-confidence. However, the changes to the constitution still left some complications in the relations between the cabinet and parliament. In established parliamentary democracies, the vote of non-confidence in the cabinet results in new elections and consequently in the formation of a new parliamentary coalition and cabinet. Results of the new elections can place the former parliamentary coalition in the position of the parliamentary opposition and vise versa. This fact constrains the political coalition from disrespecting the rights of political opposition. "The current majority in competitive systems must anticipate in the future having to live by the same rules it currently imposes

\footnotetext{
${ }^{60}$ From the 440 deputies that were present in the Rada on the day of voting $19.12 .06,172$ voted for, 3 voted against, 4 abstained from the voting and 261 did not vote at all. Verkhovna Rada 10February 2007 <http://gska2.rada.gov.ua/pls/radac_gs09/g_frack_list_n?ident=2018\&krit=66>.

${ }^{61}$ Bill on the parliamentary opposition, Ch.Ш, art. 15, sec. 13.
} 
upon the current minority."62 Both sides coexist in accordance with the "rules of the game" that require collaboration and compromise for the effectiveness of the parliament. The political coalition of the current parliament can become the political opposition after the next election.

In the case of Ukraine, the dismissal of the cabinet does not lead to a new election.

The dismissal of the Prime-minister of Ukraine, the vote of non-confidence by the Parliament results in the dismissal of the Cabinet. In this case the Parliament of Ukraine creates the formation of the new composition of the Cabinet in the terms and conditions that are defined by the Constitution of Ukraine. ${ }^{63}$ (Emphasis mine)

If the parliament votes for non-confidence in the government that is formed by the parliamentary coalition based on political parties, it also signifies a vote of nonconfidence in the policy and the program of the political party or parties that create the government. However, the constitution grants the right to the parliamentary coalition from which cabinet was dismissed to form another government. This undermines the principle of government accountability as a central characteristic of democracy. The principle of government alternation is not followed because the parties of the political opposition are denied the opportunity to participate in the formation of the new government. As before the reform in 2004, the constitution limits the vote of nonconfidence to the serving cabinet, not to the governing coalition itself. "The question of the cabinet accountability can not be viewed more than once during the parliamentary session and during one year after the approval of the cabinet program or during the last session of the parliament of Ukraine." $" 64$ In combination with the fixed term of the elected parliament (Ch.IV, Art. 76) this creates a situation when the cabinet that was dismissed

${ }^{62}$ David M. Olson, Democratic Legislature Institutions. A comparative View (New York: M.E. Sharpe Inc., 1994) 121.

${ }^{63}$ Constitution of Ukraine, Ch. VI, art.115, sec. 3.

${ }^{64}$ Constitution of Ukraine, Ch.IV, art.87, sec. 2. 
once by the Rada can be formed repeatedly by the same parliamentary coalition during the five year term. At the same time the political opposition has to submit to the ruling of the party or coalition that was already recognized as ineffective until the end of the parliamentary term.

\subsubsection{The power of the president}

Another manner in which the political opposition can be influential and participate in the work of the government is in collaboration with the president. In a parliamentary-presidential system, a powerful president can provide a balance of power to the government in the situation of cohabitation when the office of the president and the office of the prime-minister are held by the representatives of different political parties. In this case the president represents the political opposition.

What distinguishes the parliamentary-presidential model of opposition from the British or the German model is the fact that - during of the split party control of parliament, government and the presidency - the opposition function is performed by the parliamentary minority and the president. $^{65}$

As Duverger defined is his study of the semi-presidential regimes the "nature of the parliamentary majority and the relation between the president and majority" are essential for defining the democratic or non-democratic character of the semi-presidential regime. ${ }^{66}$ Being directly elected by popular vote the president has a legitimate mandate for power from the people of the country whereas the prime-minister is appointed by president or legislature.

The president can be considered powerful when he meets following criteria:

1. Directly elected with fixed term in office.

\footnotetext{
${ }^{65}$ Ludger Helms, "Five ways of Institutionalizing political opposition: lessons from the Advanced Democracies," Government and Opposition 39.1 (January 2004): 35.

${ }^{66}$ Maurice Duverger, "A new political system model: semi-presidential Government," European Journal of Political Research 8 (1980): 165-87.
} 
2. Power to appoint and dismiss the prime-minister and a cabinet.

3. Power of legislative initiative.

4. Power to veto the legislature.

5. Power to dissolve the legislative. ${ }^{67}$

Of these five features of the powerful president, the president of Ukraine meets four even after the constitutional reform in 2004. Under the constitution of 2004 the president maintained the rights of legislative initiative (Ch. IV, Art.93), the right to dissolve the legislature (Ch. IV, Art.90), and the right to veto the legislature (Ch. V, Art. 106, Section 30). The president is elected by popular vote for a five year term. The power to dismiss the legislature that is given to the president by the constitution of 2004 (Ch. IV, Art.90) is not a characteristic of parliamentarism at all. "A key difference between presidentialism and parliamentarism is that presidents do not have the rights to dissolve the legislature whereas prime-ministers and their cabinets do have this right., As under the old text of the constitution, the non-party character of the post of the president in Ukraine after the 2004 reform creates problems of accountability. This undermines the role of parliament and the political parties as the main actors in the political process. The relation between the non-party president and the parliamentary minority are ineffective in balancing power with the cabinet and the majority. The fact that President Yushchenko distanced himself from the political bloc Our Ukraine that was named in his honour during the 2002 parliamentary election led to the bloc's failure

\footnotetext{
${ }^{67}$ Alan Siaoroff defined the different types of mixed regimes based on the constitutional power of the President and his or her influence on the cabinet. See Alan Siaroff, "Comparative presidencies: The inadequacy of the presidential, semi-presidential and parliamentary distinction," European Journal of Political Research 42 (2003): 287-312.

${ }^{68}$ Arend Lijphart, Pattern of Democracy, Governments Forms and Performance in thirty-six countries (New Haven: Yale UP, 1999) 125.
} 
during the 2006 parliamentary election. The president of Ukraine did not consider himself to be the leader of the political party. On the contrary he took the position of the leader of the nation who is "above" the parliament and the government. As a result it left the political opposition without an important and legitimate instrument to challenge and influence the policy of the governing party.

\subsubsection{System of appointing and removing the government}

The constitutional power of the cabinet in Ukraine creates the biggest complication in the system of power sharing between the legislature and the executive. In the system of presidentialism, the cabinet is responsible to the president and can not be dismissed by the legislature. The cabinet is a representative of the president's party and its functions under his direct supervision. At the same time, the cabinet in a parliamentarian system is formed and dismissed by the legislature. The cabinet and the parliamentary coalition that appoints the cabinet belong to the same political party and often the members of the cabinet are the members of the parliament as well. ${ }^{69}$

The constitution of 2004 (Ch. IV, Art.78); prohibits members of the cabinet who, are appointed from the parliament, from combining the two positions. "The People's deputies of Ukraine can not have any other representative mandate, be in the public service, and hold gainful occupation except the academic and scientific effort." The law on the cabinet of ministers of Ukraine (Ch.2, Art.7, Section 3) that was adopted in January 2007 had the same provision:

In the case of the submission to the Verkhovna Rada the candidacy of the member of the Cabinet of Ministers of Ukraine who is a member of the Verkhovna Rada, the candidate submits the

\footnotetext{
${ }^{69}$ In the Westminster model of parliament the members of the cabinet are members of the ruling coalition in the parliament.
} 
application for his resignation as the People's Deputy of Ukraine in the case of his/hers appointment to the cabinet of ministers of Ukraine. ${ }^{70}$

Thus the constitution and the Law on the cabinet of ministers of Ukraine undermine the principle of the parliamentary democracy, in which the cabinet is formed on the basis of party membership and is subject to the control of parliament and therefore political parties of the opposition. When the cabinet is part of the parliamentary coalition, the political opposition can question the policy and program of the government by participating in the parliamentary debates and working on parliamentary committees. When the cabinet members are not parliamentarians, the political opposition has less access to them and therefore less influence on their conduct.

According to the constitution of 2004 (Ch. IV, Art.85); the parliamentary coalition has the right to appoint the prime-minister and the cabinet, except for the minister of the defence and the minister of foreign affairs. The president retained the right to submit the candidacy of the minister of defence and the minister of the foreign affair for parliament's approval (Ch. VI, Art.106, Section 10). This vagueness in the power distribution between the president and the cabinet has already created a situation of stalemate. $^{71}$ The ministers nominated by the president take positions which are already in structural conflict with the prime-minister and the cabinet he governs.

\footnotetext{
${ }^{70}$ Zakon Ukrainy pro Kabinet Ministriv Ukrainiy (Law on Cabinet of Ministers of Ukraine) no 514, dated 21 December 2006, Verkhovna Rada 25 January $2008<$ http://zakon1.rada.gov.ua/cgibin/laws/main.cgi?nreg=514-16>.

${ }^{71}$ The process of the dismissal of the Minister of Foreign Affairs Borys Tarasyuk, who was appointed from the opposition to the cabinet of Viktor Yanukovich, created an embarrassing position for Ukraine's international reputation. Prime-Minister Yanukovich blocked the work of the Ministry of Foreign Affairs by authorizing his advisor Anatoliy Grishchenko to arrange his official visits to Europe passing over the authority of minister of foreign affairs and his office. See Serhii Rakhmanin, "Total Discord" Serkalo nedeli No 47, 9-15 Dec 2006, 23 January 2007< http://www.zn.ua/1000/1030/55341/>.
} 


\subsection{Conclusion}

From the analysis of the constitutional framework of Ukraine and its influence on the effective political opposition we can draw the following conclusions.

The formal separation of power in the text of the constitution did not take place in the relations between the main political actors: the president, parliament and the cabinet. The principle of "power sharing"72 as one of the main criteria for consolidating democracy is not practiced in Ukraine.

The constitutional framework in 2002 did not promote the alternation in power between the opposition and government due to an imbalance in power between the executive and the legislature. The constitutional power of the president and his wide authority limited the role of the legislature and consequently of the political parties in the formation of the government. In combination with the mixed electoral system that existed in 2002 and the fixed elected term of the president and the legislature it inhibited the political opposition from being effective and influential on the government policy.

The brief success of the political opposition during the 2004 presidential elections happened despite the institutional framework in Ukraine but due to the many situational factors. The end of the term of the incumbent president, the personalization of the presidential campaign and the support of the world community helped the political opposition to achieve its goal, access to power. However, after the elections the political opposition had to work under the old institutional framework of the country and as a result it failed to be effective.

\footnotetext{
${ }^{72}$ Arend Lijphart defined power sharing as "participation of representatives of all significant communal groups in political decision making." In his view power sharing is a more appropriate term than power separation for the newly independent countries with divided society and mixed regimes. Arend Lijphart, “Constitutional design fro divided societies," Journal of Democracy 15.2 (April 2004): 96-109.
} 
The constitutional reform in 2004 did little to facilitate the political opposition. The amendments to the constitution did not change the system of semi-presidentialism, which prevents the strengthening of the political parties and for that reason the institutionalized political opposition. Under the new system, parliamentary-presidential, the conflict between the president, the cabinet and the parliament has only increased.

First, after the constitutional reform the power of the president was reduced, but the spectrum of his constitutional rights is still wide. The president is directly elected for a fixed term that is the characteristic of the presidential system of governing rather than parliamentarian. He has the right to dismiss the legislature and the right of veto over the legislative initiative. He is the head of the national Security Council and the Supreme Commander-in-chief of the military forces in Ukraine and he has the right to the appointment of selected cabinet ministers. He appoints and dismisses the prosecutor general with parliament's agreement. Thus, the president's authority precludes the current political system from being classified as parliamentary-dominated. Furthermore, the non-party character of the post of president diminished the influence of the political opposition in the Rada after the 2006 parliamentary election, even though the importance of the political parties in general increased.

Second, the increased power of the parliament after the constitutional reform of 2004 did not result in its increased effectiveness. The constitution of 2004, the Reglament 06 and the Agreement of the coalition of deputies' factions did not define the status and role of the political opposition. Instead they duplicate each other on the role and rights of the parliamentary coalition. 
Third and finally, the amendments to the constitution in 2004 happened during the presidential campaign in 2004 and in the face of the future parliamentary election in the spring of 2006. For these reasons they were not carefully considered by politicians, rather they were adopted rashly, this may lead to future amendments. The constitutional reform 2004 increased the role of the political parties in the political process; nevertheless the political parties are weak and underdeveloped. It causes the diffusion of the political opposition and it ineffectiveness. 


\section{CHAPTER 4 \\ ELECTORAL SYSTEM AND THE EFFECTIVENESS OF THE POLITICAL OPPOSITION}

A country's institutional framework, including its electoral system and its constitution establishes the rules of the game for all political actors in that society. The electoral system of the country has direct influence on the character of the party competition during elections and on the ability of the opposition to be elected and equally represented in the parliament alongside the parties of the government. The type of electoral system adopted is generally considered to affect the structure of political competition. The literature suggests ${ }^{1}$ that the combination of the single plurality electoral system and the two party system supports the formation of the strictly competitive opposition. An opposition party may succeed in an election by competing with the party of power without the need for collaboration with the other parties. The multi-party political system and the proportional representation electoral system are conducive to the development of the cooperative or competitive-cooperative opposition. The parties of the opposition need to cooperate before and then after the election in order to form a coalition government.

The parties of the future Orange team participated in the 2002 election as opposition parties. The electoral bloc Viktor Yushchenko Our Ukraine got the largest percentage of votes, $23.57 \%$ nation wide from the PR party list. Together with the Socialist party of Ukraine and the BYT (Bloc Yulia Tymoshenko), the future Orange team had $37.70 \%$ of the votes from PR, which resulted in these groups collectively being assigned $49.77 \%$ of the seats from the PR list. However this did not lead to the

${ }^{1}$ Dahl 336-338. 
cooperative type of the opposition, nor the formation of a parliamentary coalition by these opposition parties. The opposition parties were in a disadvantage in the 2002 parliamentary election because the mixed electoral system undermined the candidates belonging to political parties and benefited candidates who were unaffiliated with any party in single-member districts (SMD). As a result from the total number of 222 elected candidates in the SMD $41.89 \%$ or 93 were unaffiliated. This allowed the pro-president bloc "For United Ukraine", which had $11.77 \%$ of the vote nation wide but $29.73 \%$ of the seats in the SMD to form a parliamentary majority, even though it had received less electoral support than the parties of the future Orange team.

The 2006 parliamentary election was the second election for the parties of the Orange team. Changes to the constitution led to the adoption of a clear proportional representation closed party list electoral system that increased the chances of the small political parties, including the parties of the Orange team to be elected to the Rada. ${ }^{2}$ It was the first parliamentary election to happen after the Orange revolution and under the presidency of Viktor Yushchenko. The Orange team received 41.93\% of the votes in the election. This translated to a majority, 243 or $54 \%$ of the 450 seats in the Rada in accordance with the largest remainder Hare quota electoral formula. However, the members of the Orange team did not cooperate, and thus they failed to create a parliamentary coalition and government despite an electoral system that benefited them.

In order to answer the main research questions (why were the parties of the Orange team not able to create a parliamentary majority and a coalition government after

\footnotetext{
${ }^{2}$ Zakon Ukrainy Pro vnesennya zmin do Zakonu Ukrainy "Pro vybory Narodnykh Deputative Ukrainy (The Law of Ukraine on the changes to the Law of Ukraine on elections of peoples' Deputies of Ukraine), no 2777-IV dated 07 July 2005, Verkhovna Rada <http://zakon1.rada.gov.ua/cgibin/laws/main.cgi?nreg=2777-15>.
} 
their success during the Orange revolution and the 2006 parliamentary election?) this chapter will look at the electoral system in Ukraine during the 2002 and the 2006 elections and its influence on the opposition parties and their ability to be elected and form a coalition government.

In the study of the influence of the electoral system on the political parties, a number of scholars ${ }^{3}$ test the degree to which an electoral system allocates seats in a legislature to a party in a manner that is consistent with the proportional representation of the votes which that party received. As Douglas W. Rae opined: “... [T]he functional domain of electoral laws lies in the conversion of elective outcomes into parliamentary party systems." ${ }^{4}$ According to Rae this can be tested by looking at three main components of the electoral system: ballot structure, electoral formula and district magnitude. ${ }^{5}$ However, these conditions apply to countries with an institutionalised party system and a strong electoral system. ${ }^{6}$ The more the political party system of the country is structured the more that the electoral system influences the character of the party competition. The electoral law of a country should establish the rules for the competition for the political parties and these rules are respected by all political actors and must not

\footnotetext{
${ }^{3}$ The seminal works are by Douglas Rae, Arend Lijphard and Matthew Shuggart together with Rein Taagepera on the electoral systems and their effects on the party representation. See Douglas W. Rae, The Political Consequences of Electoral Laws (New Haven: Yale UP, 1971), Arend Lijphard, Electoral Systems and Party Systems, A Study of Twenty-seven democracies (New York: Oxford UP,1994), Matthew S. Shugart, Rein Taagepera, Seats and Votes, The effects and Determinants of Electoral Systems (New Haven: Yale UP, 1989)

${ }^{4}$ Rae 63.

${ }^{5}$ For the purpose of this study Rae's definition of the district magnitude will be used as follows: "This variable may be called the magnitude of the district, and is defined as the number of seats assigned by the electoral law to any district." Rae 19.

${ }^{6}$ The definition of the strong electoral system will be that that developed by Giovanni Sartori who defined it as follows: "... [A]n electoral system that unquestionably exerts a manipulative influence (on the voter) will be classifie as being a strong electoral system," Giovanni Sartori, "The influence of Electoral Systems: Faulty Laws or Faulty Method?" Electoral Laws and Their Political Consequences, ed. Bernard Grofman and Arend Lijphard (New York: Agathon Press, Inc., 1986) 55.
} 
benefit either the government or the opposition during the elections, which are fair and free. As Jean Blondel stated:

It must be appear to those temporarily in opposition that they can gain power without breaking the rules. And that they will be accepted once in power if they have previously abided by the rules. ${ }^{7}$

In Ukraine the multi-party political system is not fully institutionalised, as was discussed in the previous chapter. As for the electoral system, the provisions of the electoral law in Ukraine related to the system for the candidates' nomination, their party affiliation and the system of casting votes have a greater impact on the electoral process and the outcome of the election than the size of the district magnitude. ${ }^{8}$ For that reason, in addition to the main variables such as electoral formula and ballot structure, the system of candidate nomination and their party affiliation will also be considered.

The chapter will analyse the electoral system in Ukraine during the 2002 and 2006 parliamentary elections in accordance with the classical theories on the electoral system by Douglas Rae, Arend Lijphart, Matthew Shugart and Michael Gallagher. The main purpose is to define the level of influence of the electoral law on the ability of the opposition and minority to equally participate in the election, be elected and proportionally represented in the legislature. The set of variables that will be tested are: the system of a candidate's nomination, the electoral formula, and the coefficient of disproportionality between the votes the parties receive and the subsequent share of seats the political parties are allotted. Two parliamentary elections, 2002 and 2006 in which the parties of the Orange team participated, will be reviewed.

\footnotetext{
${ }^{7}$ Jean Blondel, Political Parties. A genuine Case for Discontent? (London: Wildwood House, 1978) 87.

${ }^{8}$ The nation wide district magnitude in Ukraine is 225 seats. This would produce a high degree of proportionality, however; it would not explain the character of the parties' competition and the presence of numerous political parties per district.
} 
The chapter concludes that the electoral law and the mixed electoral system that existed in the 2002 were not favourable for political parties in general, to the parties of the opposition in particular. First, the complicated system for the party nomination of candidates in SMD resulted in a high number of unaffiliated self-nominated candidates in the SMD. Second, the electoral formula that allocated half of the seats to the SMD and half of the seats to the proportional representation party list increased the role of individual non-party candidates in the SMD rather than political parties. Third, the simple plurality formula in combination with a high number of candidates per district lowered the threshold of inclusion for the elected candidates, thus it allowed them to win seats with a small percentage of valid votes. Finally, the presence of the closed party list placed the authority with parties and their leaders' to choose the candidates for the election. In Ukraine where political parties are weak, this had the effect of limiting the electorate's choice to the leaders of the parties and blocs rather than for preferable specific candidates for the future government.

The electoral law governing the 2006 election coupled with the clear proportional electoral system was more favourable for the proportional representation of the political parties and the parties of the opposition. First, the lower legal threshold of 3\% allowed the small political parties such as the Socialist party to participate separately in the election and succeed. However the law did not require that candidates on the party list be members of the party. This resulted once again in a high number of unaffiliated candidates on the lists of the parties and blocs. Second, the presence of the closed party list gave the power to the leaders of the parties and blocs rather the electorate to choose the preferable candidates for the future government. Third, the changes to the electoral 
formula in 2006 benefited the Orange team. Under the new formula the Orange team was allocated $54 \%$ of the seats in the Rada despite having obtained only $41.93 \%$ of the popular vote. However, the political culture of parties' leaders prevented them from sharing power after the election despite their majority status. ${ }^{9}$

\subsection{Overview of the Electoral Systems in Ukraine}

The first parliamentary election since independence ${ }^{10}$ took place in March 1994 in accordance with the Law of Ukraine on the election of People Deputies of Ukraine (electoral law of 1994), which was adopted three months before the election. ${ }^{11}$ The two rounds absolute majority electoral formula was used. The country was divided into 450 SMD, the size of the Rada; the candidate who attracted the absolute majority of the votes in the district was elected (Art.1, Section 3). In the case that none of the candidates obtained a majority of the votes, the two leading candidates then participated in a second round of voting and the candidate with the majority of votes was elected. The electoral law of 1994 (Art. 43 Section 3) also required a $50 \%$ turn-out among eligible voters in order for the results of the election to be valid; if the turn-out is less, a re-election must take place. 58333 candidates participated in election of which only $11 \%$ were nominated by parties. ${ }^{12}$ From the total number of 450 seats on the day of the election only 49 deputies were elected. The second round of voting resulted in 338 elected deputies. The absolute majority electoral formula and the $50 \%$ turn-out requirement resulted in high

\footnotetext{
${ }^{9}$ The influence of the political culture of the Ukrainian society on the effectiveness of the parties of the political opposition will be discussed in Chapter 5. For that reason it will be not discussed here.

${ }^{10}$ The parliamentary election in March 1990 took place before Ukraine's independence in August 1991.

${ }^{11}$ Zakon Ukrainy pro Vybory Narodnykh Deputativ Ukrainy (Law of Ukraine on the elections of People Deputies of Ukraine) no 3623-XII, dated 18 November 1993, Verkhovna Rada 13 July2007 <http://zakon.rada.gov.ua/cgi-bin/laws/main.cgi?page=1\&nreg=3623-12>.

${ }^{12}$ Sarah Birch, "The Ukrainian Parliamentary and Presidential Election of 1994," Electoral Studies 14.1(1995): 93-99.
} 
numbers of re-elections in many districts. As a consequence of this defect in the electoral law of 1994, almost one year after the first round of the election, the remaining 112 seats were still vacant. The Communist party of Ukraine won the greatest number of seats from among the parties, 83. However the largest group of deputies, 163, were not members of parties. This illustrated the weakness of political parties in Ukraine. The SMD electoral system fostered a personalisation of electoral choice rather than the party choice. Thus, in order to increase the role of the political parties in the society, some changes in the electoral system were necessary.

The second parliamentary election took place in March 1998 under the mixed electoral system in accordance with the newly passed Law of Ukraine on the election of People Deputies of Ukraine (electoral law of 1997). ${ }^{13}$ As in the case of the 1994 parliamentary election, the new electoral system was adopted less than a year prior to the election. According to the electoral law of 1997 (Art.1, Section 1,2); half of the composition of the Rada was elected from 225 SMD and the other half from the proportional representation party list multi-member nation wide district. In order to be elected in the SMD the candidates had to obtain a simple plurality of the votes instead of an absolute majority as was required under the former electoral law in the previous election pursuant to Art.43, Section 4. For the proportional representation multimember district a threshold of $4 \%$ of votes cast was established in order for a party to be allocated seats (Art.42, Section 6). From 30 political parties that participated in the election, eight political parties reached the $4 \%$ threshold with the Communist party of Ukraine obtaining the highest figure, $24.65 \%$ of the votes from PR.

\footnotetext{
${ }^{13}$ Zakon Ukrainy pro Vybory Narodnykh Deputativ Ukrainy (Law of Ukraine on the elections of People Deputies of Ukraine) no541/97, dated 24 September 1997, Verkhovna Rada 16 September 2007 <http://zakon.rada.gov.ua/cgi-bin/laws/main.cgi?nreg=541\%2F97-\%E2\%F0>.
} 
In spite of the intent of the legal drafters, the changes in electoral law of 1997 in Ukraine did not increase the role of the political parties. The electoral formula, which provided that half the composition of Rada was to be comprised of SMD, intensified the personalization of the voting instead of placing an emphasis on party voting. As a result from the total number of 218 deputies that were elected to the Rada in 1998 from the SMD, 102 deputies were non party members and self-nominated candidates. It also complicated the process of the formation of the parliamentary majority. After being elected to the Rada many independent deputies switched parliamentary factions, which blocked the work of the parliament.

Table 4.1 Electoral Systems in Ukraine, 1994-2006

\begin{tabular}{|c|c|c|c|c|c|c|c|}
\hline $\begin{array}{l}\text { Year of } \\
\text { the } \\
\text { election }\end{array}$ & $\begin{array}{l}\text { Electoral } \\
\text { system }\end{array}$ & $\begin{array}{l}\text { Electoral } \\
\text { formula }\end{array}$ & $\begin{array}{l}\text { Type of the } \\
\text { ballot }\end{array}$ & $\begin{array}{l}\text { Legal } \\
\text { threshold }\end{array}$ & $\begin{array}{l}\text { District } \\
\text { magnitude }\end{array}$ & $\begin{array}{l}\text { Number of } \\
\text { elected } \\
\text { political } \\
\text { parties }\end{array}$ & $\begin{array}{l}\text { Number of } \\
\text { the non party } \\
\text { members } \\
\text { deputies }\end{array}$ \\
\hline 1994 & $\begin{array}{l}\text { SMD two } \\
\text { rounds }\end{array}$ & Absolute majority & Categorical & & 1 & 15 & 163 \\
\hline 1998 & $\begin{array}{l}\text { Mixed two } \\
\text { tiers }\end{array}$ & $\begin{array}{l}\text { SMD-plurality. } \\
\text { PR - Largest } \\
\text { remainder Hare } \\
\text { quota }\end{array}$ & Categorical & $4 \%$ & $\begin{array}{l}\text { SMD -1 } \\
\text { PR - 225 }\end{array}$ & 8 & 145 \\
\hline 2002 & $\begin{array}{l}\text { Mixed two } \\
\text { tiers }\end{array}$ & $\begin{array}{l}\text { SMD-plurality. } \\
\text { PR - Largest } \\
\text { remainder Hare } \\
\text { quota }\end{array}$ & Categorical & $4 \%$ & $\begin{array}{l}\text { SMD -1 } \\
\text { PR - 225 }\end{array}$ & 6 & 131 \\
\hline 2006 & List PR & $\begin{array}{l}\text { PR - Largest } \\
\text { remainder Hare } \\
\text { quota }\end{array}$ & Categorical & $3 \%$ & 450 & 5 & 95 \\
\hline
\end{tabular}

Source: table produced by author based on the typology by Arend Lijphard, Matthew S. Shugart and Martin.P.Watternberg and data from the Central Electoral Commission of Ukraine. See Arend Lijphard, Electoral Systems and Party Systems, A Study of Twenty-seven democracies (New York: Oxford UP, 1994), Matthew S. Shugart and Martin.P.Watternberg, Mixed-Member Electoral Systems. The Best of Both World (New York: Oxford UP, 2001), <http:/www.cvk.gov.ua/pls/vd2002/webproc0v>. 


\subsection{Parliamentary Election}

This election took place under the multi-tier mixed electoral system ${ }^{14}$ in accordance with the Law of Ukraine on the Election of the Peoples Deputies of Ukraine (electoral law of $2001)^{15}$ which was enacted in October 2001 , five months prior to the election. This was the same electoral system that was used in 1998 but with amendments related to the system of the candidates' nomination. Half of the composition of the Rada, 225 members, was elected in the SMD, the nominal tier ${ }^{16}$. The other half were elected on the basis of the PR party list (Art.2, Section 2,3) in the nation wide multi-member constituency with 225 territorial districts, the list tier. The official threshold of $4 \%$ of the votes' nation wide was established for the parties and blocs in order to be elected and be allotted seats in the Rada.

\subsubsection{The system of candidate nomination}

Single-member district. According to the electoral law of 2001 the right to be nominated in the SMD was given to the political parties, blocs (Chapter VII, Art. 38, Section 1) and to the individual Ukrainian citizen (Art.38, Section 2). The right to be nominated by a collective of workers was removed from the law of 2001, as was the requirement for

\footnotetext{
${ }^{14}$ According to the typology by Matthew S. Shugart and Martin.P.Watternberg: "Electoral system employed multiple tiers if seats are allocated in two (or more) overlapping sets of districts, such that every voter may cast one or more votes that are employed to allocate seats in more than one tier." See Matthew S. Shugart Shugart and Martin.P.Watternberg, Mixed-Member Electoral Systems. The Best of Both World (New York: Oxford UP, 2001) 10.

${ }^{15}$ Zakon Ukrainy pro Vybory Narodnykh Deputativ Ukrainy (The Law of Ukraine On Elections of People's Deputies of Ukraine) no 2766-III, dated 18 October 2001, Verkhovna Rada 19 October 2007 <http://zakon1.rada.gov.ua/cgi-bin/laws/main.cgi?nreg=2766\%2D14\&p=1185383754148193>.

${ }^{16}$ According to the typology by Matthew S. Shugart and Martin P. Watternberg this is defined as follows: "Under nominal voting, voters cast votes for candidates by name and seats are allocated to individual candidates on the basis of the votes they receive. List votes, on the other hand, 'pool' among multiple candidates nominated on a list submitted priori to the election by a party, alliance, or other political organization." See Shugart and Wattenberg, 10.
} 
candidates to collect 30000 signatures from each region of the country for his nomination. In order to be nominated by a political party, a candidate needed to submit an abstract form from the meeting of the party or bloc during which he or she was nominated with the signature of the leader of the party or bloc (Chapter VII, Art. 42, Section 1). The party meeting during which the candidate or candidates were nominated must have a minimum quorum of 200 delegates (Chapter VII, Art.40, Section 6). The party must have been registered with the Ministry of Justice at least one year before the election (Chapter VII, Art.38, Section 1) and the party must inform the Central Electoral Commission not later than two days prior to the meeting in which the candidate nomination is to take place.(Art.40, Section 9).

For self-nomination in the SMD the procedure was less complex. The candidate had to obtain the application form for his or her self-nomination from the electoral commission of the SMD in which he or she was going to stand for election (Chapter VII, Art.38, Section 2). A monetary deposit was required for the registration instead of the collective signatures (Art.43, Section 2). From the total number of 3084 of candidates that were registered in the SMD, almost half 1537 were self-nominated. ${ }^{17}$ From among 1754 party member candidates, 207 or $13.47 \%$ were self-nominated. The biggest number of self-nominated candidates were registered in the eastern regions of Ukraine, which were loyal to the pro-Kuchma bloc "For United Ukraine", and in the capital Kyiv as Table 4.2 shows. For example, from 361 candidates in the SMD in Donetskya oblast, 217 or $60.11 \%$ of the candidates were self-nominated. From 183 in the Kharkivska oblast, 96 or $52.46 \%$ were self-nominated. In Kyiv, where many deputies

\footnotetext{
${ }^{17}$ Central Electoral Commission of Ukraine 01 August 2007 $<$ http://www.cvk.gov.ua/pls/vd2002/webproc0v>.
} 
and members of the business elite resided, there were 250 candidates and from them 139

or $55.6 \%$ were self-nominated.

Table 4.2 Number of Candidates (SMD) by Regions, 2002 election

\begin{tabular}{|c|c|c|c|}
\hline Region, oblast & Party nominated & Self-nominated & Total in the region \\
\hline Autonomy republic of Crimea & 57 & 59 & 116 \\
\hline Vinnizka region & 63 & 60 & 123 \\
\hline Volinskya region & 38 & 21 & 59 \\
\hline Dnipropetrovska region & 112 & 98 & 210 \\
\hline Donetska region & 144 & 217 & 361 \\
\hline Zhytomir region & 35 & 32 & 67 \\
\hline Zakarpatska region & 31 & 46 & 77 \\
\hline Zaporizhska region & 47 & 65 & 112 \\
\hline Ivano-Frankivsk region & 27 & 32 & 59 \\
\hline Kyivska region & 71 & 54 & 125 \\
\hline Kirovograd region & 35 & 41 & 76 \\
\hline Luganska region & 78 & 57 & 135 \\
\hline Lvivska region & 77 & 64 & 141 \\
\hline Mykolaivska region & 46 & 32 & 78 \\
\hline Odeska region & 75 & 65 & 140 \\
\hline Poltavska region & 63 & 75 & 138 \\
\hline Rivnenska region & 38 & 30 & 68 \\
\hline Sumska region & $\overline{42}$ & 21 & $6 \overline{3}$ \\
\hline Ternopilska region & 35 & 35 & 70 \\
\hline Kharkivska region & 87 & 96 & 183 \\
\hline Khersonska region & 48 & 43 & 91 \\
\hline Khmelnitska region & 52 & 36 & 88 \\
\hline Cherkaska region & 50 & 44 & 94 \\
\hline Chernivetska region & 27 & 31 & 58 \\
\hline Chernigivska region & 44 & 33 & 77 \\
\hline City Kyiv & 111 & 139 & 250 \\
\hline City Sevastopol & 14 & 11 & 25 \\
\hline Total & 1547 & 1537 & 3084 \\
\hline
\end{tabular}

Source: table used from the Central Electoral Commission of Ukraine, 25 July 2007

$<$ http://www.cvk.gov.ua/pls/vd2002/webproc0e>.

The electoral law of 2001 did not require party membership for candidates. To

illustrate (see Figure 4.1), from the total number of 3084 candidates in SMD, 1330 or

$43.13 \%$ were non-party members' candidates. Those 1330 candidates in the SMD

comprised $81.15 \%$ of the total number of 1639 of the non-party members' candidates in the 2002 election, the remaining 309 non-party members candidates were from the PR list. $^{18}$

${ }^{18}$ Central Electoral Commission of Ukraine 15 September 2007 $<$ http://www.cvk.gov.ua/pls/vd2002/webproc0v>. 


\section{Figure 4.1 Party Affiliations of the Candidates, 2002 Parliamentary Election}

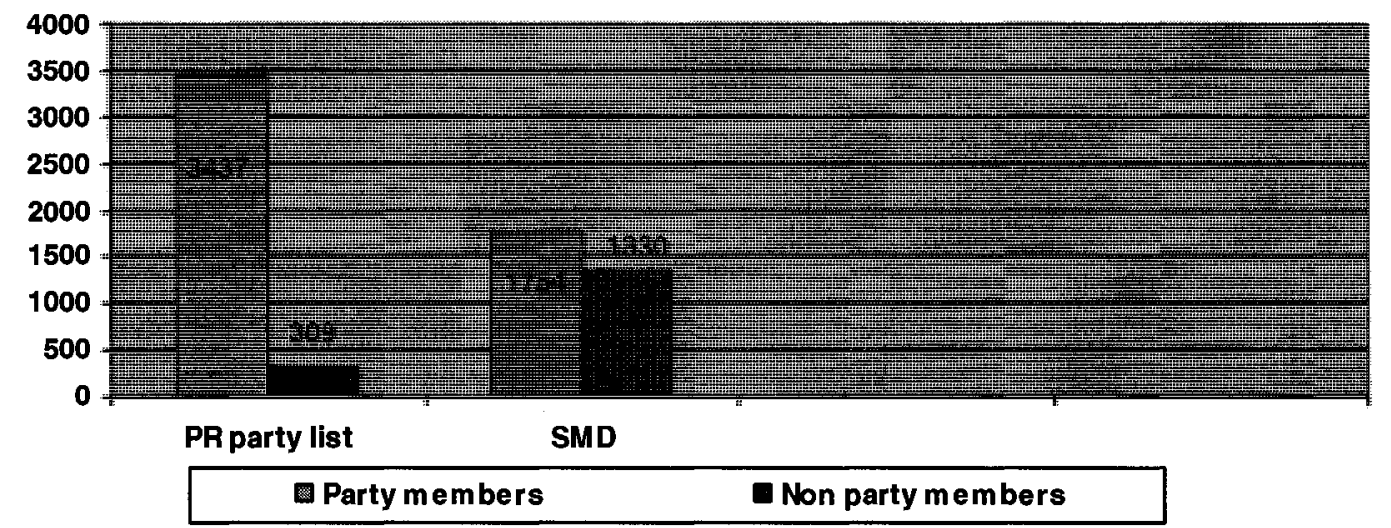

Source: graph produced by author based on data from the Central Electoral Commission of Ukraine, 15 September $2007<\mathrm{http}: / /$ www.cvk.gov.ua/pls/vd2002/webproc0v>.

This benefited the pro-government candidates. Having administrative and financial resources, many pro-government candidates could be elected in the SMD as non-party members and self-nominated and avoid any party association and thus further responsibility and accountability to the electorate. As Sara Birch noted: "A Law which downplayed party affiliation had the added advantage of allowing the 'party of power' to win seats without having to resort overtly to a label designating a discredited ideology."19

Another disadvantage for the political parties in the electoral law of 2001 was the regulation of the number of the candidates per district. Article 40, Section 3 of the electoral law of 2001 limited the right of the party or bloc to nominate only one candidate in each constituency; however, there was no regulation for the self-nominated non-party members candidates. This allowed the government to place as many candidates as possible in the loyal districts thus lowering the "threshold of inclusion" ${ }^{20}$ for winning candidates in accordance with the simple plurality formula. As Tables 4.3 shows, the

\footnotetext{
${ }^{19}$ Sarah Birch, "Ukraine: the struggle for democratic change," Embodying Democracy, Electoral System Design in Post-Communist Europe, Sarah Birch, Frances Millard, Marina Popescu, Kieran Williams (New York: Palgrave Macmillan, 2002) 149.

${ }^{20}$ The definition by Arend Lijphard is adopted, it states as follows: "The threshold of representation (or inclusion) is the minimum percentage of the vote that can earn a party a seat under the most favorable circumstances." See Lijphard 25.
} 
average number of candidates per district in the 2002 election was 13.71 . This made the average threshold of inclusion in the 2002 election at the level of $7.23 \%$ of the votes. ${ }^{21}$ In Kyiv where the government was in a stronger position than the opposition, the number of candidates per district was at its highest, 20.83 which theoretically made the threshold of inclusion $4.8 \%$. In the eastern region of Donetska oblast, the average number of registered candidates per district was at the 15.7 , thus the threshold of inclusion was at the $6.37 \%$ of the votes, respectfully.

Table 4.3 Threshold of Inclusion (SMD), 2002 Parliamentary Election

\begin{tabular}{|l|l|l|l|l|}
\hline Region, oblast & $\begin{array}{l}\text { Number of } \\
\text { candidates }\end{array}$ & $\begin{array}{l}\text { Number of } \\
\text { SMD in region }\end{array}$ & $\begin{array}{l}\text { Average number of } \\
\text { candidates per SMD in } \\
\text { region }\end{array}$ & $\begin{array}{l}\text { Average threshold } \\
\text { of inclusion per } \\
\text { region, \% }\end{array}$ \\
\hline Autonomy republic of Crimea & 116 & 10 & 11.6 & 8.62 \\
\hline Vinnizka region & 123 & 8 & 15.38 & 6.5 \\
\hline Volinskya region & 59 & 5 & 11.8 & 8.48 \\
\hline Dnipropetrovska region & 210 & 17 & 12.35 & 8.1 \\
\hline Donetska region & 361 & 23 & 15.7 & 6.4 \\
\hline Zhytomir region & 67 & 6 & 11.17 & 8.95 \\
\hline Zakarpatska region & 77 & 6 & 12.83 & 7.79 \\
\hline Zaporizhska region & 112 & 9 & 12.44 & 8.04 \\
\hline Ivano-Frankivsk region & 59 & 6 & 9.83 & 10.17 \\
\hline Kyivska region & 125 & 8 & 15.63 & 6.4 \\
\hline Kirovograd region & 76 & 5 & 15.2 & 6.58 \\
\hline Luganska region & 135 & 12 & 11.25 & 8.89 \\
\hline Lvivska region & 141 & 12 & 11.75 & 8.51 \\
\hline Mykolaivska region & 78 & 6 & 13 & 7.69 \\
\hline Odeska region & 140 & 11 & 12.73 & 7.86 \\
\hline Poltavska region & 138 & 8 & 17.25 & 5.8 \\
\hline Rivnenska region & 68 & 5 & 13.6 & 7.35 \\
\hline Sumska region & 63 & 6 & 10.5 & 9.52 \\
\hline Ternopilska region & 70 & 5 & 14 & 7.14 \\
\hline Kharkivska region & 183 & 14 & 13.07 & 7.65 \\
\hline Khersonska region & 91 & 5 & 18.2 & 5.5 \\
\hline Khmelnitska region & 88 & 7 & 12.57 & 7.96 \\
\hline Cherkaska region & 94 & 7 & 13.43 & 7.44 \\
\hline Chernivetska region & 58 & 4 & 14.5 & 6.9 \\
\hline Chernigivska region & 77 & 6 & 12.83 & 7.79 \\
\hline City Kyiv & 250 & 12 & 20.83 & 4.8 \\
\hline City Sevastopol & 25 & 2 & 12.5 & 7.23 \\
\hline Total & 3084 & 225 & 13.71 & \\
\hline Source: table produce & & \\
\hline
\end{tabular}

Source: table produced by author based on data from the Central Electoral Commission of Ukraine, 25 July $2007<$ http://www.cvk.gov.ua/pls/vd2002/webproc0e>.

Proportional representation closed party list. For the nomination in the single multimandate national district from the PR party list, a party meeting with at least 200

\footnotetext{
${ }^{21}$ The threshold of inclusion is calculated as following $\mathrm{T}$ inc $=100 \% / \mathrm{N}$ where $\mathrm{N}$ - number of candidates in a district.
} 
delegates was required in order to nominate candidates. The party or bloc had to submit the list of the candidates of the party or bloc in their order of party preference to the Central Electoral Commission 87 days prior to the election, (electoral law of 2001; Chapter VII, Art.40, Section 7). As was the case for the nominations in SMD, the electoral law of 2001 did not require the candidates to be a member of the party. Article 40, Section 4 of the law stated "A party (bloc) can nominate a person as a candidate to be a deputy who is a member of this party (bloc) or non-party citizen, who according to the Art. 8 of this law has a right to be elected as a deputy (emphasis mine)." This provision in combination with the closed party list provided the party leaders with effective control over the list of the candidates rather then giving the choice directly to the voters. Instead of choosing the preferred candidates of the party or bloc for the future government as occurs in the open party list electoral system, the voter was in effect providing a free pass to the leaders of the parties and blocs to choose its deputies. The electoral law of 2001 did little to encourage or obligate party membership; this in turn led to high number of non party member candidates in the election. For example, among the 33 political parties and blocs that participated in the election, 27 had non-party members' candidates on their list of the candidates. Four electoral blocs including the pro-government bloc "For United Ukraine" (leader Volodymir Litvin), the electoral bloc Viktor Yushchenko Our Ukraine, the electoral bloc “Team of Winter Generation" (leader Valery Khoroshkovsky), and the Communist party of Workers and Peasants (leader Serhiy Heniyevskiy), had nonparty member leaders. The practical impact of this large group of non- party members PR elected deputies was the increased likelihood of shifting party allegiances within the parliament. Parties and blocs attempted to induce non party members to join their side. 


\subsubsection{Electoral formula, coefficient of the disproportionality}

As was described earlier, the mixed electoral system in the 2002 election was based on the nominal and list tiers for the seat allocation with a parallel linkage between them. ${ }^{22}$ Each voter had to cast two types of ballots - one for the individual candidate in 225 single member districts and the second for the party or bloc in the nation-wide district. Single-member district. In order to be elected in the SMD, the candidate had to receive a plurality of votes from the voters that took part in the voting in the constituency (electoral law of 2001; Chapter X, Art.74, Section 10). If only one candidate competed in a district, in order to win the election, the candidate must obtain a greater number of votes than the votes "against all" option, which is found on the ballot (Chapter X, Art.74, Section 10, paragraph 2).

From the total number of the 222 seats $^{23}$ that were elected in the SMD, 92 , the largest number of deputies, were elected as non-party members. Among them, 12 won elections with less than $20 \%$ of the votes cast in the constituency and only 10 won their constituency with more than $50 \%$ of the vote. ${ }^{24}$ The average percentage of votes that the winning non-party members' candidates received in their constituency was $32.95 \%$ of the votes, which is lower than the effective threshold of $37.5 \%$ for the simple plurality electoral formula with one member district magnitude. ${ }^{25}$

\footnotetext{
${ }^{22}$ According to Matthew S. Shugart and Martin P. Watternberg the parallel linkage between tiers means that party performance in the SMD does not have influence on the result in multi-member districts and vice versa. See Shugart and Wattenberg, 14.

${ }^{23}$ Three seats were vacant after the election.

${ }^{24}$ The data was used from the official result of the 2002 election in the SMD, Central Electoral Commission of Ukraine 18 September 2007 <http://www.cvk.gov.ua/pls/vd2002/webproc0v>. ${ }^{25}$ According to Arend Lijphard who defines the effective threshold as the average threshold between the threshold of inclusion (minimum percentage) and the threshold of exclusion (maximum percentage). Teff= $75 \% / \mathrm{M}+1$ where the $\mathrm{M}$ - is the size of the district magnitude. See Lijphard 183.
} 
The same was true about the party candidates that won seats in the SMD. The pro-Kuchma bloc "For United Ukraine" won the largest number of seats of the parties and blocs, 66 from the total 222 number of seats in the SMD or $29.33 \%$. The average percentage of the votes received by winning candidates was $34.13 \%$. Bloc Viktor Yushchenko Our Ukraine won 40 seats with an average percentage of votes of $41.98 \%$ followed by the Communist party with seven seats with an average vote share of $21.21 \%$ in each district that they won. The Kuchma loyalist Social Democratic party (united) won five seats with an average of $25.44 \%$ of the vote per district. The Socialist party won only two seats and the BYT did not win any.

From the total number of 24416677 valid votes ${ }^{26}$ cast in the SMD, 1922784 or $7.88 \%$ ballots were marked "against all". In some constituencies the percentage of the votes "against all" was as high as $22.26 \%$ of the votes. ${ }^{27}$ Since the electoral law of 2001 (Art.74, Section 10) combined votes "against all" together with invalid votes in the tabulation of total votes cast, it did not accurately reflect the district's electorate choice. ${ }^{28}$ This is because it artificially increased the number of the valid votes, thus lowered the percentage of votes for the winning candidate.

Due to the fact that the candidates can be elected with the less than the majority of the valid votes cast in the district, the simple plurality electoral formula is considered the

\footnotetext{
${ }^{26}$ According to the law, the valid votes counted as the differences between the total number of voters that participated in the voting and the total number of invalid ballots. See Zakon Ukrainy pro Vybory Narodnykh Deputativ Ukrainy no 2766-III, dated 18 October 2001.

${ }^{27}$ In the single member district №2 in Crimea during the 2002 election the percentage of votes "against all" was equal at the $22.26 \%$ with a winning candidate receiving $32.76 \%$ votes.

Central Electoral Commission of Ukraine 18 November $2007<$ http://www.cvk.gov.ua/pls/vd2002/webproc0v>.

${ }^{28}$ This provision of Law was criticized by OSCE (Organization for Security and Co-operation in Europe) in the previous elections. See "Final report of the OSCE/ODIHR Election Mission on parliamentary elections in Ukraine in 2002," OSCE 13 November 2007< http://www.osce.org/documents/odihr/2002/05/1293_en.pdf $>$.
} 
least proportional formula for the distribution of the seats. "Under the test of the

proportionality, plurality systems come off very badly; they produce greater

disproportion than majority or PR system under almost any circumstances." 29 This

proved to be true in the case of Ukraine.

The Gallagher index ${ }^{30}$ is considered the most accurate measure of the

disproportionality of the electoral formula in circumstances of multi-party systems with a high number of parties such as in Ukraine. ${ }^{31}$ This index will be used to test the deviation of the proportionality between the vote and the seat percentage for political parties in the nominal tier in the 2002 election.

$$
\mathrm{G}=\sqrt{ }\left(1 / 2 \sum\left\{\mathrm{V}_{\mathrm{i}}-\mathrm{S}_{\mathrm{i}}\right\}^{2}\right)=\sqrt{ }\left(1 / 2\left(\sum 257.01\right)=\sqrt{ } 128.50=11.34 \%^{32}\right.
$$

Where the $\mathrm{V}_{\mathrm{i}}$ - vote percentage for the $i$-th party and the $\mathrm{S}_{\mathrm{i}}-$ seat percentage.

Table 4.4 Deviation of Proportionality (SMD), 2002 Election

\begin{tabular}{|l|l|l|l|l|}
\hline Political parties & $\begin{array}{l}\text { \% of votes, } \\
\text { Vi * }\end{array}$ & $\begin{array}{l}\text { Number of } \\
\text { seats } \\
\text { (SMD) }\end{array}$ & $\begin{array}{l}\text { \% of seats } \\
\text { (SMD) Si }\end{array}$ & (Vi-Si)2 \\
\hline Bloc Viktor Yushchenko "Our Ukraine" & 14.52 & 40 & 18.46 & 15.52 \\
\hline Communist Party of Ukraine & 10.36 & 7 & 3.15 & 51.98 \\
\hline Bloc "For a United Ukraine" & 16.36 & 66 & 29.73 & 178.76 \\
\hline Socialist Party of Ukraine & 3.77 & 2 & 0.9 & 8.24 \\
\hline SDPU (United) & 2.44 & 5 & 2.25 & 0.04 \\
\hline Bloc "Unity" & 1.42 & 4 & 1.80 & 0.14 \\
\hline $\begin{array}{l}\text { "Democratic party of Ukraine - Party Democratic } \\
\text { Union" }\end{array}$ & 2.81 & 3 & 1.35 & 2.13 \\
\hline Unaffiliated candidates & 41.65 & 93 & 41.44 & 0.04 \\
\hline Party of National- Economic Development & 0.22 & 1 & 0.45 & 0.05 \\
\hline Ukrainian Sea Party & 0.12 & 1 & 0.45 & 0.11 \\
\hline Total & & & & 257.0133 \\
\hline Others & 6.40 & 0 & 0 & 40.96 \\
\hline TOTAL & 100 & 222 & 100 & 297.97 \\
\hline
\end{tabular}

${ }^{29}$ Douglas W. Rae, The Political Consequences of Electoral Laws (New Haven: Yale UP, 1971) 27.

${ }^{30}$ Michael Gallagher, "Proportionality, Disproportionality and Electoral Systems," Electoral Studies 10.1 (March 1991): 33-51.

${ }^{31}$ In comparison to other indexes such as the Rae index, which depends on the number of parties in the election, the Gallagher index measures the disproportionality of the system instead of each party. For a comparative analysis of the indexes of disproportionality of the electoral system see Lijphard, p. 58 .

${ }^{32}$ For example Rae index $(\mathrm{R}=\Sigma(\mathrm{Vi}-\mathrm{Si}) / \mathrm{N}$, where $\mathrm{N}$-number of included parties) will produce less deviation in the case of Ukraine, $R=3.42 \%$ because of its dependence on the number of parties in the election.

${ }^{33}$ The parties that obtained less than $1 \%$ of the votes, except parties that won some seats, were obtained in order to avoid the miss calculation of the index when square the differences between vote and seat percentage. 
Source: table produced by author based on data from the Central Electoral Commission of Ukraine, 01 August 2007 <http://www.cvk.gov.ua/pls/vd2002/webproc0e>.

* For the percentage of votes for the each party in the SMD the data used from the Sarah Birch analyses of the electoral systems in the post-communist countries who used the valid votes, including "against all". See Sarah Birch, Appendix A, Electoral Systems and Political Transformation in Post-Communist Europe (New York: Palgrave Macmillan, 2003) 176.

After the calculation we have the index of deviation of proportionality for the nominal tie at the level of $11.34 \%$ within the range of 0 (absolutely proportional) to $100 \%$ (absolutely disproportional). To understand the intensity of the index for nominal tier we should test the degree of disproportionality between the vote and seats percentage for the list tier in the 2002 election. ${ }^{34}$

Proportional representation party list. According to the electoral law of 2001 (Art.76, Section 3-7); the distribution of seats from the proportional representation party list took place in accordance with the largest remainder Hare quota formula. The quota was defined (Art.76, Section 5) as the total number of votes cast for the political parties that obtained $4 \%$ threshold divided by the number of seats, 225 .

From the 33 political parties that participated in the election, six reached the $4 \%$ threshold. The electoral bloc Viktor Yushchenko Our Ukraine, as Table 4.5 shows, won the largest percentage of votes from the proportional representation ballot, $23.6 \%$ for 70 seats. In combination with the BYT which took fourth place with $7.2 \%$ for 22 seats and the Socialist party of Ukraine, $6.9 \%$ for 24 seats, the political opposition had $37.7 \%$ of votes from the proportional representation party list with 116 seats.

The Communist party of Ukraine took $19.98 \%$ for 59 seats. Pro-president bloc "For United Ukraine" gained $11.77 \%$ for 35 seats and the Social Democratic party (united) that was loyal to President Kuchma gained $6.27 \%$ for 19 seats.

\footnotetext{
${ }^{34}$ Nominal and list tiers refer to the SMD (nominal tier) when the voter votes for one candidate and to the PR party list (list tie) when the voter votes for the list of the party candidates.
} 
Table 4.5 Results of the 2002 Parliamentary Election

\begin{tabular}{|l|l|l|l|l|}
\hline Political parties and blocs & $\begin{array}{l}\text { \% of } \\
\text { votes }\end{array}$ & $\begin{array}{l}\text { Number of } \\
\text { seats } \\
\text { (PR) }\end{array}$ & $\begin{array}{l}\text { Number of } \\
\text { seats (SMD) }\end{array}$ & Total \\
\hline Bloc Viktor Yushchenko "Our Ukraine" & 23.57 & 70 & 40 & 110 \\
\hline Communist Party of Ukraine & 19.98 & 59 & 7 & 66 \\
\hline Bloc "For a United Ukraine" & 11.77 & 35 & 66 & 101 \\
\hline Yulia Tymoshenko Bloc & 7.26 & 22 & & 22 \\
\hline Socialist Party of Ukraine & 6.87 & 20 & 2 & 22 \\
\hline SDPU (United) & 6.27 & 19 & 5 & 24 \\
\hline Bloc "Unity" & 1.09 & 0 & 4 & 4 \\
\hline $\begin{array}{l}\text { "Democratic party of Ukraine - Party Democratic } \\
\text { Union" }\end{array}$ & 0.87 & 0 & 3 & 3 \\
\hline Party of National-Economic Development & & 0 & & 1 \\
\hline Ukrainian Sea Party & & 0.11 & 1 & 1 \\
\hline Unaffiliated & & & 1 & 93 \\
\hline TOTAL & & 225 & 222 & 447 \\
\hline
\end{tabular}

Source: table produced by author based on data from the Central Electoral Commission of Ukraine,27 January 2007 <http://www.cvk.gov.ua/pls/vd2002/webproc0v>

The largest remainder Hare quota electoral formula is considered one of the most proportional systems for the distribution of the seats for the political parties according to Arend Lijphart. "The Hare quota is impartial as between small and large parties and tends to yield closely proportional results."35

To test this hypothesis we will use once again the Gallagher index of deviation of the proportionality.

$$
\mathrm{G}=\sqrt{ }\left(1 / 2 \sum\left\{\mathrm{V}_{\mathrm{i}}-\mathrm{S}_{\mathrm{i}}\right\}^{2}\right)=\sqrt{ }\left(1 / 2 \sum 107.16\right)=\sqrt{53.58}=7.32 \%{ }^{36}
$$

Where the $\mathrm{V}_{\mathrm{i}}$ - vote percentage for the $i$-th party and the $\mathrm{S}_{\mathrm{i}}-$ seat percentage.

After the calculation we have the coefficient of disproportionality for the seats distribution for the list tier in the 2002 election at the level equal to $7.82 \%$ within the range of 0 (absolutely proportional) to $100 \%$ (absolutely disproportional) that is lower in comparison to the index of disproportionality for the nominal tier at $\mathrm{G}=11.34 \%$.

Table 4.6 Deviation of Proportionality (PR list), 2002 Election

\begin{tabular}{|l|l|l|l|l|l|l|}
\hline Political parties & $\begin{array}{l}\text { \% of } \\
\text { votes } \\
\text { (PR), } \\
\text { V }\end{array}$ & $\begin{array}{l}\text { \% of valid } \\
\text { votes (PR), } \\
\text { Vi* }\end{array}$ & $\begin{array}{l}\text { Number } \\
\text { of seats } \\
\text { (PR) }\end{array}$ & $\begin{array}{l}\text { \% of } \\
\text { seats } \\
\text { (PR), } \\
\text { Si }\end{array}$ & $\begin{array}{l}\text { Advantag } \\
\text { e ratio, } \\
\text { S/V }\end{array}$ & $\begin{array}{l}\text { (Vi- } \\
\text { Si)2 }\end{array}$ \\
\hline
\end{tabular}

\footnotetext{
${ }^{35}$ Lijphart 23.

${ }^{36}$ The parties with the less than $1 \%$ of the votes were excluded from the calculation in order to avoid the underestimation of the index.
} 


\begin{tabular}{|l|l|l|l|l|l|l|}
\hline Bloc Viktor Yushchenko "Our Ukraine" & 23.57 & 25.13 & 70 & 31.1 & 1.24 & 35.64 \\
\hline Communist Party of Ukraine & 19.98 & 21.30 & 59 & 26.22 & 1.23 & 24.20 \\
\hline Bloc "For a United Ukraine" & 11.77 & 12.55 & 35 & 15.56 & 1.24 & 9.06 \\
\hline BYT (Bloc Yulia Tymoshenko) & 7.26 & 7.74 & 22 & 9.78 & 1.26 & 4.16 \\
\hline Socialist Party of Ukraine & 6.87 & 7.32 & 20 & 8.89 & 1.21 & 2.47 \\
\hline SDPU (United) & 6.27 & 6.69 & 19 & 8.44 & 1.26 & 3.06 \\
\hline $\begin{array}{l}\text { Election bloc of Political Parties "Nataliya } \\
\text { Vitrenko Bloc" }\end{array}$ & 3.22 & 3.44 & 0 & & 0 & 11.83 \\
\hline $\begin{array}{l}\text { "Women for the Future" All-Ukrainian Political } \\
\text { Union }\end{array}$ & 2.11 & 2.25 & 0 & & 0 & 5.06 \\
\hline $\begin{array}{l}\text { Election bloc of Political Parties "Team of } \\
\text { Winter Generation" }\end{array}$ & 2.02 & 2.16 & 0 & & 0 & 4.67 \\
\hline Communist Party of Ukraine (renew) & 1.39 & 1.49 & 0 & & 0 & 2.22 \\
\hline The Green Party of Ukraine & 1.30 & 1.39 & 0 & & 0 & 1.93 \\
\hline Political Party "Apple" & 1.15 & 1.23 & 0 & & & 1.51 \\
\hline Election bloc of Political Parties "Unity" & 1.09 & 1.16 & 0 & & 0 & 1.35 \\
\hline Others (parties with less than 1\%) & & 6.17 & 0 & & 0 & 38.07 \\
\hline Total & & 100 & 225 & & & 145.23 \\
\hline
\end{tabular}

Source: table produced by author based on data from the Central Electoral Commission of Ukraine, 01 August 2007 <http://www.cvk.gov.ua/pls/vd2002/webproc0e>.

- The percentage of valid votes, excluding the votes "against all" and invalid votes.

$\bullet$

Therefore, hypothetically if the 2002 election had happened under a strict PR

electoral system with the largest remainder Hare quota formula instead of the mixed

electoral system, the proportional representation of the political parties would have

increased. Consequently this would have increased the number of the seats for the parties

of the opposition thus increasing their chance to form a parliamentary majority and a

coalition government.

To conclude, the mixed electoral system that existed prior to the electoral reform

of 2005 provided favorable conditions for the oligarch non-party candidates that ran in

the SMD. ${ }^{37}$ The stringent process of the party nomination for the candidates in the SMD

also limited the parties' participation in these contests. The parties and blocs of the

${ }^{37}$ The electoral reform in 2005 changed the electoral system from the mixed system to the proportional representation system with threshold of $3 \%$. See Zakon Ukrainy Pro vnesennya zmin do Zakonu Ukrainy "Pro vybory Narodnykh Deputative Ukrainy" (The Law of Ukraine on the changes to the Law of Ukraine on Elections of Peoples' Deputies of Ukraine), no 2777-IV, dated 07 July 2005 Verkhovna Rada <http://zakon1.rada.gov.ua/cgi-bin/laws/main.cgi?nreg=2777-15>. 
political opposition were disadvantaged by this law and for that reason their effectiveness was significantly diminished. Scholars have theorised about the effect of the mixed electoral system that "the larger the proportion of the total number of seats devoted to SMD tier, the greater will be the impact of SMD on overall outcomes in the system." 38 In Ukraine this electoral system benefited the unaffiliated candidates in the SMD who had more financial and administrative resources and were usually pro-government. Furthermore, these members are sought after by existing parties in the hopes of forming a parliamentary majority. As Sara Whitmore noted:

Although the new electoral law increased the role of parties in parliament, it produced a polarized composition that made the body prone to deadlock. In turn, this created opportunities for the president to direct parliament by manipulating its constituent factions. ${ }^{39}$

Having the support of the constitutionally powerful President Kuchma and using the system of the bargaining, the bloc "For United Ukraine" was able to attract a majority of the unaffiliated candidates and create a parliamentary majority passing over the political opposition. "In 2002, the opposition actually won the parliamentary elections but failed to create a government, ceding the initiative to the more skillful and crafty propresidential forces. $" 40$

\subsection{Parliamentary Election}

This election took place under the Law of Ukraine of the election of People Deputies of Ukraine (electoral law of 2005) that changed the mixed electoral system to the PR closed party list. According to the electoral law of 2005 (Art.1, Section 4) in order to be elected

\footnotetext{
${ }^{38}$ Robert G. Moser, Ethan Scheiner, "Mixed electoral systems and electoral system effects: controlled comparison and cross-national analysis," Electoral Studies 23(2004): 575-599.

${ }^{39}$ Sarah Whitmore, "Faction institutionalization and parliamentary development in Ukraine," Journal of Communist Studies and Transition Politics 19.4 (December 2003): 41-64.

${ }^{40}$ Mykola Riabchuk, "Learning democracy: The Internal Political Development of Ukraine since 1991," The Ukrainian Quarterly LXII.2 (Summer 2006): 217-221.
} 
the party had to obtain enough votes to reach the $3 \%$ legal threshold in the one nation wide multi-member district with its 225 territorial districts.

According to political theorists (Lijphard, 1994; Shugart and Taagepera, 1989; Birch, 2002) proportional representation electoral system leads to an increase in the number of parties that compete in the election. It also provides more opportunities for small political parties compete and succeed.

PR increases the number of parties and the variety of options among which people can choose, and so it makes elections more competitive in that most parties have a chance to win at least one seat, and so they attempt to mobilize their electors throughout the country. ${ }^{41}$

This is consistent with Ukraine's experience; the changes in the electoral system led to an increase in the number of the parties that participated in election. There were 33 parties in the 2002 election, this increased to 45 in the 2006 election.

\subsubsection{The system of candidate nomination}

The process of the candidate nomination experienced some changes. According to the electoral law of 2005(Art.10, Section1); only political parties and blocs had the right to nominate candidates in the 2006 election. This was a change from the previous electoral law of 2001, which had given the rights to the parties together with selfnominated candidates in the SMD. These changes were intended to increase the role of the political parties in the election and to facilitate the ability of the electorate to express its preference with greater specificity.

Although the changes modestly enhanced the role of the political parties in the electoral process, the amended law still had many of same problems of the previous law. As in the 2002 election, in order for the political party or bloc to be entitled to nominate

\footnotetext{
${ }^{41}$ Robert K. Christensen, Edward R. Rakhimkulov, Charles R. Wise, "The Ukrainian Orange Revolution brought more than a new president; what kind of democracy will the institutional changes bring?"

Communist and Post-Communist Studies 38(2005): 207-230.
} 
candidates in the election, the party or the parties of the bloc had to be registered one year prior to the election (Art.10, Section 2). This could limit the ability of newly formed parties to participate in the election.

The electoral law of 2005 limited the right of candidate nomination to the political parties, but it did not require the party membership of the candidates (Art.57, Section 2). Coupled with the presence of the closed party list system, the law still left the party leaders with control over the candidates on the list rather than the rank and file party members. This also led to a high number of the non-party members candidates on the list of the parties and blocs as well as a high number of new candidates. For example, from the total number of the 7595 candidates from the 45 political parties, 840 or $11.06 \%$ were non-party members' candidates. The percentage of the candidates who were running for the first time was $75.5 \%$ or 5734 from $7595 .^{42}$ The list of the BYT, as Figure 4.2 shows, consisted of 79 non-party candidates and most of them were placed in the top 150 positions of her candidates list. ${ }^{43}$ In other words they were most likely to actually become deputies when seats were allocated. Most party members were located further down the list, meaning that they were less likely to become deputies. The percentage of the candidates that were running for the first time was $63.39 \%$ of the total number of 407 bloc candidates. The bloc Our Ukraine had 40 non-party candidates, 16 in the top 100 of the bloc's list. Half of the candidates on the bloc's list, 198 or $50.9 \%$ were running the first time. The Party of Regions had a lower number of non-party candidates, 41 of 403 candidates, or $9.23 \%$. However the percentage of the parties' candidates that were

\footnotetext{
${ }^{42}$ Central Electoral Commission of Ukraine 14 September 2007 <http://www.cvk.gov.ua/pls/vnd2006/W6P001>.

${ }^{43}$ According to the official list of the candidates from the BYT, Central Electoral Commission of Ukraine 20 July 2007<_http://www.cvk.gov.ua/pls/vnd2006/W6P001>.
} 
running for the first time in the election was $70 \%$ of the total number of the party candidates. ${ }^{44}$ The more experienced and established Socialist and the Communist parties had the lowest level of non-party candidates, 22 or $5.65 \%$ from a total number of 389 candidates for the Socialist party and eight or $1.79 \%$ from the 448 candidates for the Communist party. Nevertheless, the percentage of the candidates who were running the first time was at the $62.72 \%$ for the Socialist party and the $57.37 \%$ for the Communist party, respectfully. ${ }^{45}$

\section{Figure 4.2 Party Affiliations of the Candidates, 2006 Parliamentary Election}

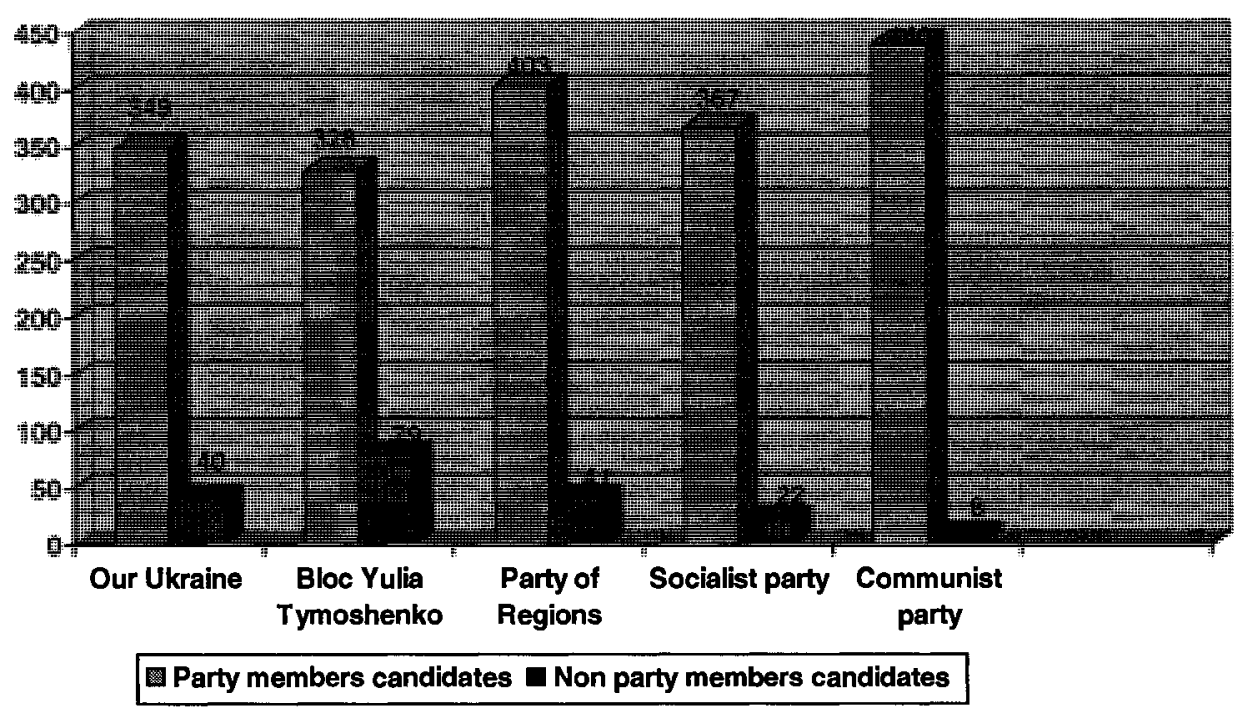

Source: graph produced by author based on data from the Central Electoral Commission of Ukraine, 20 July 2007<_http://www.cvk.gov.ua/pls/vnd2006/W6P001>.

\subsubsection{Electoral formula}

As in the 2002 election, the distribution of the party seats in 2006 election took place in accordance with the largest remainder Hare quota system. The quota was defined as the total number of votes cast for the political parties that obtained the $3 \%$ popular vote threshold divided by the number of seats, 450 (Art.96, Section 7). Then the

\footnotetext{
${ }^{44}$ Ibid.

${ }^{45}$ From the total number of the 45 parties that participated in the election, I use the list of the candidates of the five parties which were elected to Rada.
} 
total number of votes cast for each political party was divided by quota and the resulting whole number represented the total number of seats that the political party gained (Art. 96, Section 9). The parties which received the largest remainder from the whole number have the right to gain one more seat. If two political parties have the same remainder the party with the biggest percentage of votes had the right to gain the seat.

From the 45 political parties that participated in the election, five were elected. The election in 2006 was described as the most free and fair parliamentary election in Ukraine since its independence. ${ }^{46}$ The Party of Regions took first place with $32.14 \%$ of votes. The BYT finished second with $22.29 \%$ of the votes with the bloc Our Ukraine taking the third place with $13.95 \%$ of votes. The parties of the Orange team received in total $41.93 \%$ of the votes cast in the election. The level of the disproportionality of the electoral formula for the seats distribution in the 2006 election increased in comparison to the PR electoral formula in the 2002 election.

\subsubsection{The coefficient of the disproportionality}

The level of proportionality of the electoral formula in the 2006 election will be tested using the Gallagher index of deviation of the proportionality.

$$
\mathrm{G}=\sqrt{ }\left(1 / 2 \sum\left\{\mathrm{V}_{\mathrm{i}}-\mathrm{S}_{\mathrm{i}}\right\}^{2}\right)=\sqrt{ }\left(1 / 2 \sum 135.81\right)=\sqrt{ } 67.91=8.24 \%^{47}
$$

Where $V_{i}$ - percentage of valid votes for $i$-th party, $S_{i}$ - percentage of seats for $i$-th party

The value of index, $\mathrm{G}=8.24 \%$ suggests that strict $\mathrm{PR}$ closed party list electoral system and largest remainder Hare quota electoral formula with a reduced legal threshold

\footnotetext{
${ }^{46}$ According to the country report by Freedom House, the electoral process in 2006 in Ukraine was scored at 3.25 according to the scale from 1 to 7 with 1 -absolutely free and $7-$ not free. It improved from 4.25 in the 2004. Freedom House 15 November 2007

$<$ http://www.freedomhouse.org/template.cfm?page $=47 \&$ nit $=409$ \&year $=2006>$.

${ }^{47} \mathrm{As}$ was the case for the calculation of the index for the 2002 election, the parties that obtained less than $1 \%$ of the valid votes were excluded from the calculation in order to avoid the misscalculation of the coefficient.
} 
actually increased the level of disproportionality from $7.32 \%$ in the 2002 to $8.87 \%$ in

2006. However this electoral formula was favourable for the parties of the Orange team in the 2006 election. Having $41.93 \%$ of the votes, less than a majority, the parties of the Orange team gained the majority of seats, 243. The largest remainder Hare quota electoral formula, as Tab. 4.8 shows, allowed the parties of the Orange team to gain in total 243 seats or $54 \%$ of the total number of 450 seats.

Table 4.7 Deviation of Proportionality (PR), 2006 Election

\begin{tabular}{|c|c|c|c|c|c|c|}
\hline Political parties & $\begin{array}{l}\text { \% of } \\
\text { votes, } \\
\text { V48 }\end{array}$ & $\begin{array}{l}\text { \% of valid votes, } \\
\text { excluding } \\
\text { "against all", Vi }\end{array}$ & $\begin{array}{l}\text { Number } \\
\text { of seats }\end{array}$ & $\begin{array}{l}\% \text { of } \\
\text { seats, } \\
\mathrm{Si}\end{array}$ & $\begin{array}{l}\text { Advantage } \\
\text { ratio, A } \\
\text { (Si/Vi), \% }\end{array}$ & (Vi-Si)2 \\
\hline Party of Regions & 32.14 & 33.38 & 186 & 41.33 & 1.24 & 63.2 \\
\hline Bloc of Yulia Tymoshenko & 22.29 & 23.16 & 129 & 28.67 & 1.24 & 30.36 \\
\hline Bloc "Our Ukraine" & 13.95 & 14.50 & 81 & 18 & 1.24 & 12.25 \\
\hline Socialist party of Ukraine & 5.69 & 5.92 & 33 & 7.33 & 1.24 & 1.99 \\
\hline Communist party of Ukraine & 3.66 & 3.81 & 21 & 4.67 & 1.23 & 0.74 \\
\hline $\begin{array}{l}\text { People's Opposition Bloc of Natalia } \\
\text { Vitrenko }\end{array}$ & 2.93 & 3.05 & 0 & 0 & 0 & 9.30 \\
\hline Bloc of Lytvyn & 2.44 & 2.54 & 0 & 0 & 0 & 6.45 \\
\hline $\begin{array}{l}\text { Ukrainian National Bloc of Kostenko } \\
\text { and Pliushch }\end{array}$ & 1.87 & 1.95 & 0 & 0 & 0 & 3.80 \\
\hline Party "Viche" & 1.74 & 1.81 & 0 & 0 & 0 & 3.28 \\
\hline "Civil Political Bloc Pora-PRP" & 1.47 & 1.53 & 0 & 0 & 0 & 2.34 \\
\hline Opposition Bloc "Ne Tak" & 1.01 & 1.05 & 0 & 0 & $\overline{0}$ & 1.10 \\
\hline Party "Renaissance" & 0.96 & 1.00 & 0 & 0 & 0 & 1.00 \\
\hline $\begin{array}{l}\text { Other parties } \\
\text { (with less than } 1 \% \text { of the votes) }\end{array}$ & 4.54 & 6.31 & $\overline{0}$ & 0 & 0 & 39.82 \\
\hline Total & 100 & 100 & 450 & 100 & & 157.48 \\
\hline
\end{tabular}

Source: table produced by author based on data from the Central Electoral Commission of Ukraine 23 September 2007<http://www.cvk.gov.ua/info/protokol_cvk.pdf>.

Thus the parties of the Orange team had a greater likelihood to be represented in the Rada in accordance with the list PR system with a $3 \%$ threshold in the 2006 election than in the 2002 election under the mixed electoral system. Moreover the lower threshold favoured the small political parties such as the Socialist party of Ukraine, providing them with the power that allowed them to have influence on the political process in the Rada

\footnotetext{
${ }^{48}$ According to the Ukrainian law, the percentage of the votes for each party is counted in the proportion to the total number of voters that participated in the election, including the invalid votes and votes "against all." Central Electoral Commission of Ukraine 23 September $2007<$ http://www.cvk.gov.ua/info/protokol_cvk.pdf $>$.
} 
comparable to the larger political parties. ${ }^{49}$ Thus the failure of the Orange team to create the parliamentary majority and coalition government after the election was not attributable to the electoral system, but to other factors such as political culture that prevented them from sharing power with each other.

\subsection{Conclusion}

After the analysis of the electoral systems in place during the 2002 and the 2006 parliamentary elections and their influence on the representation of the parties of Orange team, some conclusions may be drawn.

First, the mixed electoral system in the 2002 election did not favour political parties in general and the parties of the opposition in particular. The electoral formula allocated one half of the composition of the Rada to the SMD, which resulted in a disproportionate influence of this mandate over the PR party list. The government had better administrative and financial resources in these constituencies, this allowed government supported candidates to win a majority of these seats. Second, the electoral law of 2001 did not require the party affiliation of the candidates in the elections and this resulted in a high number of the unaffiliated candidates with less direct responsibility to the electorate than party affiliated candidates who were bound by the policies promised by their parties. Third, the simple plurality formula in the SMD and the presence of a high number of the candidates per district allowed candidates to be elected with as low as $5 \%$ of the valid votes cast in that district. Finally, the presence of the two types of ballots with the parallel links between them did not support the collaboration between the parties' candidates in the SMD and the multi-party districts; this provided the government

\footnotetext{
${ }^{49}$ The leader of the Socialist party of Ukraine Oleksandr Moroz eventually left the Orange team and signed the coalition agreement with the Party of Regions. He was elected later as the speaker of the Parliament.
} 
with the potential for the future manipulation of the results of the election through covert funding and support to candidates unaffiliated with an unpopular government.

In the 2006 election, the revised electoral law of 2005 was more conducive to the representation of political parties. First, the strict proportional representation electoral system with a lowered threshold of $3 \%$ of the votes cast in the nationwide district improved the chances for the political parties, including the parties of the opposition to be elected and represented in the Rada. However the electoral law did not require the party affiliation of the candidates; this led to a high number of unaffiliated candidates. Second, the presence of the closed party list gave the power to the party leader rather than voters to choose the candidates, which consequently decreased the deputies' accountability to the electorate. Third, despite the higher index of disproportionality of the electoral formula in the 2006 election, the largest remainder Hare quota formula benefited the parties of the Orange team. It allowed them to secure $54 \%$ of the seats with only $41.93 \%$ of the votes. However, the parties of the Orange team were not effective in using it. Their inability to create a parliamentary coalition and therefore the government was not because of the specifics of the electoral system as it existed during the 2006 election. It was other factors which prevented the cooperation that was necessary to consolidate and to from a government.

Finally, the frequency of changes in the electoral law in Ukraine precludes the assessment of the long term effect of the electoral system. In order to see the influence of the electoral system on the party system, a cycle of at least two or three elections should take place under the same system. "Healthy partisan competition requires that the electoral system - the basic rules of the democratic election game - be broadly supported 
and not be changed too frequently. In particular they should not be changes for narrow partisan purpose. ${ }^{, 50}$ In Ukraine, the changes in the electoral law usually take place prior to the election and thus are biased and have a situational character. They are not carefully considered and usually adopted in favour of the current government to preserve its power rather then to improve the parties' representation in Rada.

${ }^{50}$ Lijphard 151. 


\section{CHAPTER 5 \\ POLITICAL CULTURE AND THE EFFECTIVENESS OF THE POLITICAL OPPOSITION}

The political culture of a country has a direct impact on its level of

democratization. ${ }^{1}$ It also has impact on the character of the political opposition and its effectiveness. If the mass political culture supports the cooperation between members of society and if it fosters trust in the political institutions of the country, the parties of the political opposition are better able to mobilize the electorate. Alternatively, in countries where the political culture does not promote trust in the political institutions nor among its citizens, the parties of the opposition have a diminished ability to influence the government and to be effective in holding the government to account for its actions. A country's political culture is not uniform; different parts of society have different attitudes. The political elite act as a leader of public opinion. ${ }^{2}$ The political elite's system of values and beliefs and its relation with the mass political culture can provide further explanation for the failure or the success of the democratic institutions in the country.

The political culture of Ukraine also influences the type of the political opposition and its effectiveness. If the leaders of the Orange team, a part of Ukraine's political elite, strongly support the democratic values and its institutions, if they have a high level of trust in their compatriots than they will be more willing to cooperate with each other in forming a coalition government and in sharing the power. A higher level of personal

\footnotetext{
'For the purpose of this study Walter Rosenbaum's definition of the political culture will be used: "The collective orientation of people toward the basic elements in their political system. We are interested in how large masses of citizens evaluate their political institutions and officials." See Walter Rosenbaum, Political Culture (New York: Praeger Publishers, 1975) 4.

${ }^{2}$ For the purpose of this study the political elite is defined as the group of the politically influential people that has access to policy making process such as the members of parliament, leaders of the political parties, members of the cabinet.
} 
trust among a country's citizens can increase the level of their political cooperation and political efficacy. Politically active citizens have a stronger belief in the capacity to influence the government. The government is more accountable and responsible in a society where citizens can effectively respond to the government's decisions. Thus the political parties, including the opposition parties, will be more willing to cooperate with each other in order to represent the public interest and to avoid punishment from the electorate in the next election.

Data relevant to the political elite in Ukraine was not available; therefore this study cannot provide an analysis of the political culture of the political elite in Ukraine. However, it is suggested that the mass political culture of Ukraine, the system of the citizens' beliefs and values, their trust or distrust in the state's main political institutions, the level of the political participation and political efficacy can provide explanations for the success or failure of Ukraine's opposition parties.

In order to answer the main research question (why the parties of Orange team failed to create a coalition government after the Orange revolution and the 2006 parliamentary election?) this chapter will test the relations between the mass political culture in Ukraine and its influence on the effectiveness of parties of the political opposition. The classical approaches by Gabriel Almond, Sydney Verba ${ }^{3}$ and Robert Dahl $^{4}$ together with Walter Rosenbaum on political culture will be used and three sets of variables will be tested: public attitudes towards governmental structures, orientations towards others in the political system, and the level of the political activity in Ukraine. The main purpose is to define the type of mass political culture in Ukraine (parochial,

\footnotetext{
${ }^{3}$ Gabriel A Almond, Sidney Verba, The Civic Culture. Political Attitudes and Democratic Democracy in Five Nations (Boston and Toronto: Little, Brown and Company, 1965).

${ }^{4}$ Robert A. Dahl., eds., Political Opposition in Western Democracies (New Haven: Yale UP, 1966).
} 
subject or participant) before and after the Orange revolution and to assess its influence on the behaviour of the political elite, including leaders of the Orange team. The working propositions are:

H1: the higher the level of trust between citizens the more they will be willing to collaborate with each other in achieving their goals related to the government.

H2: the higher the level of political efficacy among citizens the higher will be the level of political participation.

H3: the higher the level of the political participation, the more the government will be accountable to the public. Thus the parties, including the parties of Orange team would be more willing to cooperate in order to keep their electoral promises.

Data from 2002 and 2004 obtained from a social monitoring study entitled “Ukrainian Society 1994-2004: Sociological Monitoring" by the Institute of Sociology, National Academy of Sciences of Ukraine, Democratic Initiatives Foundation ${ }^{5}$ will be used together with the results from sociological monitoring performed in 2005 and 2006, which were after the Orange revolution. ${ }^{6}$

The second part of the chapter will examine the correlation of the relations between the political culture of the citizens according to two independent variables, age and education. ${ }^{7}$ Dependent variables will be: trust in the government, trust in the

\footnotetext{
${ }^{5}$ The sample size for the each year was 1800 respondents in all oblasts of Ukraine and Crimea. The "sampling error" does not exceed $2.34 \%$. For the full text of the result and explanation of survey see: "Sample and Peculiarities in the Data Collection" in Panina, Natalya, ed., Ukrainian Society 1994-2004: Sociological Monitoring (Institute of Sociology, National Academy of Sciences of Ukraine, Democratic Initiatives Foundation) 60, 03 January $2008<$ http://dif.org.ua/modules/pages/files/us\%2094-04e.pdf>. ${ }^{6}$ For the year 2006, the data was ordered from the Institute of Sociology, National Academy of Sciences of Ukraine, 03 January $2008<$ http://www.i-soc.com.ua/rus/index 1 .html>.

${ }^{7}$ The full data file with the results of the Sociological monitoring was not available. The author ordered the cross tables and regression analysis (SPSS file) of the relations between the variables from the Institute of the Sociology, National Academy of Ukraine. Contact person- Andriy Zotkin, PhD, Sociology. The institute does not provide the raw data.
} 
president, trust in the parliament, trust in compatriots, trust in relatives, the level of the political awareness and the level of the political efficacy. The main purpose is to test the hypothesis that young and educated citizens possess a higher level of political knowledge, are more politically active and thus can provide stronger supporter for the establishment of a democratic and effective political opposition in Ukraine in the future.

The chapter concludes that despite the success of the parties of the opposition during the Orange revolution, the mass political culture in Ukraine does not promote the formation of a united and effective political opposition.

First, the level of political trust in Ukraine is very low. The majority of citizens have high distrust in the main governmental institutions such as the parliament, president and the government. This sentiment was present before and after the Orange revolution. There was a short period of increase in the level of trust in these institutions after the Orange revolution, but this ended and trust levels decreased after the dismissal of the Tymoshenko government in July of 2005.

Second, the level of interpersonal trust in Ukraine, the trust individuals have in each other, which is a strong indicator of development of civil society, is also low. A majority of citizens do not have a high level of trust in their compatriots, which could inhibit future cooperation in collective civic actions, including participation in political parties.

Third, the low level of political awareness in Ukraine is combined with a low level of political efficacy, which is the belief in their ability to influence the political process and government decisions. This makes the government less accountable and responsible to the public, because the government does not expect that citizens will take 
any actions against government decisions, even if those decisions are adverse to the public interest. This also meant that the leaders of Orange team were less accountable to the electorate after the Orange revolution and the 2006 parliamentary election.

Finally, age and education, which are strong predictors of political activity and political trust in developed democracies, do not have a strong impact on citizens' attitudes in Ukraine. Even though a young age is associated with a higher level of political activity in Ukraine, it explains only a small percentage of the variance. As for education, a higher level of education is associated with a higher level of the distrust in compatriots. Thus the highly educated leaders of the Orange team also are likely to have a higher level of distrust in their compatriots, which includes fellow coalition members. Thus they were less willing to trust their colleagues in sharing power after the 2006 parliamentary election and forming the coalition government.

\subsection{Political Culture and the Effectiveness of the Political Opposition}

According to Gabriel Almond and Sidney Verba, the character of the political culture of a society defines the level of the democracy in a country. “... [A] successful democracy requires that citizens be involved and active in politics, informed about politics, and influential." These authors define political culture as "... [T]he specifically political orientations, attitudes toward the political system and its various parts, and attitudes toward the role of the self in the system." 9 They stated that the political culture of the country can be parochial, subject or participant. A parochial political culture, which is typical for traditional societies, is characterised by a high degree of alienation of citizens from the political process, a disbelief in their ability to influence the government

\footnotetext{
${ }^{8}$ Almond and Verba, 338.

${ }^{9}$ Ibid., 12.
} 
and a low level of political activity. A subject political culture is characterised by the passive role of its citizens in the political process, but "a high frequency of orientations toward a differentiated political system"10, even if these orientations are negative. The participant type of political culture, according to the authors, is an ideal model for the development of democracy; its main characteristics include a high level of interpersonal trust among citizens and a high level of political knowledge and participation, all of which contribute to a high level of political efficacy that leads to accountable and representative government.

Later Robert Dahl developed his theory on the relations between political culture and the political opposition. He stated that the political culture of society has influence on the type and the effectiveness of a political opposition in a country through four different measures: orientation towards political system, orientation toward other people, orientation towards cooperation and individuality, and orientation toward problem solving. ${ }^{11}$ According to Dahl, in a country where citizens have more trust in political institutions, including the government and political parties, the opposition parties are better able to mobilize the electorate. Furthermore, if this trust co-exists with the citizens' willingness to cooperate with each other because they have trust in their compatriots, the political culture that results supports the formation of an effective and cooperative political opposition.

However, when attempting to test a political culture the majority of scholars have faced difficulties in trying to find a general theory that would be applicable to different countries. This is because of the unique characteristics of each country including its

\footnotetext{
${ }^{10}$ Ibid., 17.

${ }^{11}$ Dahl 353-354.
} 
history, traditions and social values. This is true for the political culture of Ukraine. The system of modern citizens' values and beliefs can not be fully explained without some understanding of Ukraine's history.

\subsection{Overview of the Political Culture in Ukraine}

According to the Ukrainian census in $2001^{12}, 39.7 \%$ of the Ukrainian population is comprised of citizens between the ages of 30 and $60,21.4 \%$ were over $60,{ }^{13}$ and $14.3 \%$ were between the ages of 19-30. These statistics show that the majority of the Ukrainian population is made of citizens whose system of values was formed during the Soviet time or in the period of the uncertainty in early 90 -ss when the country gained its independence.

Soviet political culture, according to several studies, ${ }^{14}$ was characterized by weak representative institutions, a centralized governing style, a personalized attachment to authority combined with a low level of political knowledge and experience. It also was characterized by mobilized political participation. ${ }^{15}$ As Cynthia Kaplan noted "Soviet mass political participation was of the mobilized variety - high on ritual with little effect on policies or political leadership." ${ }^{\prime 16}$ Government involvement in all aspects of its citizens' life, and the centralized power of the Communist Party, resulted in the creation of the soviet citizen, who possessed a high support for the state authority but a

\footnotetext{
${ }^{12}$ According to the result of Ukrainian census in 2001. Ukrainian Census 200125 January 2008 $<$ http://www.ukrcensus.gov.ua/eng/results/general/age/>.

${ }^{13}$ The retirement age in Ukraine is 55 year old for women and 60 years old for men.

${ }^{14}$ Stephen White, Political Culture and Soviet Politics (London: The Macmillan Press Ltd., 1979); Archie Brown and Jack Gray, ed., Political Culture and Political Change in Communist States (London: The Macmillan Press Ltd., 1977); Stephen Welch, The Concept of Political Culture (London: The Macmillan Press Ltd., 1993).

${ }^{15}$ According to the classification by Stephen White, see: Archie Brown and Jack Gray, ed., Political Culture and Political Change in Communist states (London: The Macmillan Press Ltd., 1977)25-65.

${ }^{16}$ Cynthia S. Kaplan, "New Forms of Political Participation," in Public Opinion and Regime Change. The New politics of Post-soviet Societies, ed., Arthur H. Miller, Vicki L Hesli and William Reisinger (Boulder: Westview Press, 1993) 154.
} 
low level of political activity. In Soviet Ukraine, where a majority of citizens had peasant roots and were involved in the agriculture sector or in heavy industry, ${ }^{17}$ the Soviet brand of socialism brought an economic stability together with access to free education and medical care, which was impossible under the Tsarist rulers. It also created a generation of the citizens that relied heavily on government support, rather than on their own abilities. "The desire to live in a welfare state was rooted in deep values of the Soviet citizen." 18

The collapse of the Soviet Union and the economic stagnation of the early nineteen nineties that followed it brought changes to all areas of social and political life in Ukraine. However, the introduction of a new state was the result of compromise among the post-Soviet elite. "The end of authoritarian rule in the former Soviet Union was achieved without the involvement of mass parties, trade unions or other civic organization."19 The system of Soviet values was destroyed without the introduction of new ones. The post-Soviet elite, comprised largely from the senior rank of Soviet apparatchiks, were more concerned with their personal benefit than with establishing democracy. A consequence of this was that in the first 15 years after independence until recently, Ukraine had one of the highest levels of corruption in the world and a low level of democratic values. ${ }^{20}$ This situation also led to the formation of generation of citizens who had less trust in political institutions, government and in the system of the welfare state. Older segments of Ukrainian society still believed in a large role for the

\footnotetext{
${ }^{17}$ The World Almanac, (New York: Newspaper enterprise association, Inc., 1982) 587.

${ }^{18}$ White 101

${ }^{19}$ Arthur H. Miller, Vicki L. Hesli and William M. Reisinger, "Conceptions of Democracy among Mass and Elite in Post-Soviet Societies," British Journal of Political Studies 27: 2 (Apr.1997): 157-190, p.188. ${ }^{20}$ From 1999 to 2006 the level of corruption in Ukraine decreased only from 6.0 to 5.75 according to Freedom House report (on the scale from 1 to 7 , where 1 indicate the lowest level of corruption and 7 the highest). Freedom House 10 December 2007

<http://www.freedomhouse.org/template.cfm?page $=47 \&$ nit $=409 \&$ year $=2006>$.
} 
government in their lives, but the younger generation grew up in the conditions of uncertainly about their future. They relied more on their own resources than on the state help, they also had less trust in their compatriots.

Thus we can assume that the political culture of Ukraine' society represents a system of values and beliefs of two groups of citizens. The citizens who were in the end of their working lives when the Soviet Union collapsed were less prepared for the new conditions in their society. ${ }^{21}$ They are the least appreciated ${ }^{22}$ by the government; simultaneously they are passive towards the government. In contrast the middle age groups are more supportive of democracy but they are distrustful of and more alienated from the government. "Those alienated from the Soviet system in 1990 represented the bedrock of popular support for emerging democracy.,23

However, today the system of peoples' values and beliefs is not solely defined by their past experience. Simply relying on that would suggest that because of the Soviet past, Ukraine's political culture does not promote democratic institutions and for that reason effective political opposition. What is more important is to see how citizens in modern Ukraine evaluate their political system and political institutions. How do they evaluate their role in society and their influence on the policy-making in the government? This question can be answered by examining the system of Ukrainian citizens' values and beliefs as they relate to the main governmental institutions, their compatriots and their political efficacy before and after the Orange revolution.

\footnotetext{
${ }^{21}$ According the result of the World Value Survey in 1995 in Ukraine, the older age group (55 and older) was the most dissatisfied with their life. World Value Survey 6 February 2008 $<$ http://www.jdsurvey.net/bdasepjds/QuestionCrosstab.jsp>.

${ }^{22}$ According to the State Statistics Committee of Ukraine the average pension in Ukraine is 478 grivnas per month, that is 95 USD dollars. State Statistics Committee of Ukraine 5 February 2008 <http://www.ukrstat.gov.ua/>.

${ }^{23}$ Arthur H. Miller, "In search for regime legitimacy" in Public Opinion and Regime Change. The New politics of Post-soviet Societies 120.
} 


\subsection{The Orientation towards Governmental Structure}

The character of the political culture in a country can be explained by examining the citizens' views of the political regime in the country, its main political institutions, its symbols, its officials, its norms, and by gauging the citizens' level of satisfaction with them. ${ }^{24}$ Citizens that have high trust in their country's political institutions have higher expectations from their government. Furthermore, trust can be translated into citizens' beliefs that the government is representing their interests and is accountable to them. It also can have direct impact on their ability to be involved in the political process and to be politically active.

\subsubsection{Regime orientation}

In the period since its 1991 independence, Ukraine has experienced substantial changes in its political system, foremost of which was the change from a presidentialparliamentary model to a parliamentary- presidential one. ${ }^{25}$ These changes contributed to the Ukrainian citizens' desire for strong leadership, which some theorists suggest is a reflection of "a fear of disorder or anarchy." ${ }^{26}$ For example, in 2004, the year of the Orange revolution, according to a survey, $46.7 \%$ of the population agreed with the statement that a couple of strong leaders can do more for a country than laws. This sentiment was highest among younger voters: $50.6 \%$ of the youth agreed with the statement in comparison to $46.7 \%$ in the middle age group and $44.2 \%$ in the older

\footnotetext{
${ }^{24}$ According to the classification by Walter Rosenbaum. See Rosenbaum 6.

${ }^{25}$ These changes to the constitution were adopted in 2004, during the Orange revolution.

${ }^{26}$ See: Arthur H. Miller, Vicki L Hesli, Kristen Hill Maher, "Political Values in Russia, Ukraine and Lithuania: Sources and Implication for Democracy" in British Journal of Political Science 24:2 (1994): $183-223,188$.
} 
group. $^{27}$ (See Figure 5.1) This favorable attitude towards strong leadership only increased after the Orange revolution. For example, in $2005,59.6 \%$ of the population agreed that strong leaders can do more for a country than laws. ${ }^{28}$ It is suggested that the victory of Viktor Yushchenko and the parties of the opposition in the 2004 presidential election reflected a desire by Ukrainians to change the country's leadership from Kuchma to Yushchenko rather than to change the nature of the rules by which Ukraine was governed. Furthermore, citizens' evaluation of political institutions in Ukraine is associated with the personality of the leaders that occupy the office rather than with the government's performance.

\section{Figure 5.1}

Belief in the Strong Leadership among Age Groups, 2004

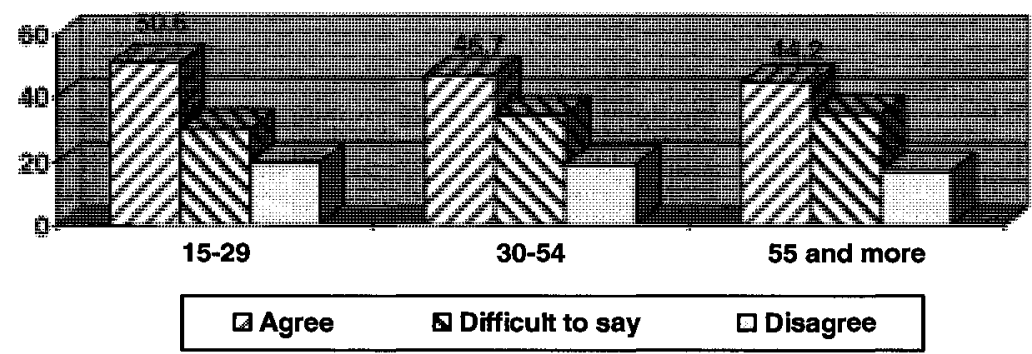

Source: graph produced by author based on the results of survey Ukrainian Society 1994-2004: Sociological Monitoring (Institute of Sociology, National Academy of Sciences of Ukraine, Democratic Initiatives Foundation) 03 January $2008<$ <ttp://dif.org.ua/modules/pages/files/us\%2094-04e.pdf>

\subsubsection{Orientation towards governmental institutions}

A subjective measurement of citizens' trust in their country's main political institutions is the citizens' level of the political knowledge about these institutions. In Ukraine, as Table 5.1 shows, the level of trust in the main political institutions is low during the years included in the study. The lowest level of trust was observed in 2002

\footnotetext{
${ }^{27}$ The question was asked: "Do you agree with the statement that couple strong leaders can do more for a country than laws?"

${ }^{28}$ Natalya Panina, ed., "Ukrainian Society - 1994-2005: year of turning point. Sociological Monitoring" (Russian text), (Kiev: Institute of the Sociology, National Academy of Sciences of Ukraine, 2005) 36.
} 
and in 2004, prior to the Orange revolution. The percentage of the population that said they "absolutely distrust" or "distrust more than trust" President Kuchma in 2002 and 2004 was $59.2 \%$ and $58.1 \%$, while only $2.9 \%$ agreed that they "absolutely trust" the president in 2002 and $2.4 \%$ in 2004 . The highest level of trust was observed in 2005 , the year after the Orange revolution and the election of Viktor Yushchenko as the president. $32.7 \%$ of the population showed "more trust than distrust" in the president and $16.5 \%$ chose "the absolute trust" option. Thus it is concluded that the Orange revolution increased the level of trust in the president. However, in 2006, after the dismissal of Yulia Tymoshenko from the cabinet, ${ }^{29}$ the level of trust in the president decreased. The percentage of the population that absolutely trusted the president declined from $16.5 \%$ in 2005 to only $5.6 \%$ in 2006.

This same trend is observed in the level of trust in the Ukrainian parliament. The percentage of the population that completely distrusts and "distrusts more than trust" the Rada has consistently been high; it reached $65.1 \%$ in 2002 , prior to the parliamentary election in March 2002. In 2004, the year of Orange revolution, the percentage of the population that absolutely distrusted or said that they "distrust more than trust" the Rada had not changed significantly, at $63.1 \%$. There was a marked increase in 2005 , after the Orange revolution. For the first time in the ten year period the percentage of the population that said they had trust in the Rada increased from $1.2 \%$ in 2004 to $4.1 \%$ in $2005 .{ }^{30}$ Even though the composition of the Rada in 2005 was the same as in $2004,{ }^{31}$ the

\footnotetext{
${ }^{29}$ The cabinet of Yulia Tymoshenko was dismissed by decree of the President Yushchenko in the summer 2005 on allegation of corruption. See Jan Maksymiuk, "Ukraine: President Sacks Government, Offering More Questions Than Answers," Radio Free Europe 09 September 2005, 16 September 2007 <http://www.rferl.org/featuresarticle/2005/9/776BA804-5279-4420-A2F8-B7B3FF8F8A0A.html>. ${ }^{30}$ According to the social monitoring by the Institute of Sociology, the average level of distrust in Rada during 1994-2004 was at 55\% of the population, Democratic Initiative Foundation 10 December 2007 <http://dif.org.ua/modules/pages/files/us\%2094-04e.pdf>.
} 
people's perception of the Rada was more positive due to the success of the opposition parties in the presidential election in 2004. In 2006, the percentage of the population that agreed that they had absolute trust in the parliament decreased from the $4.1 \%$ in 2005 to $1.6 \%$ in 2006 . The percentage of population that absolutely distrusted the parliament increased from $10.9 \%$ to $18.7 \%$ over the same period.

Similarly, the level of trust in the government is low. Trust in the new Tymoshenko government in 2005, after the Orange revolution, increased markedly from the predecessor government under Viktor Yanukovich. An interpretation of this is that distrust in the government is more dependent on the personality of the prime minister than on other factors such as the economic situation in the country or the performance of the government. ${ }^{32}$ This personalization of the political process in Ukraine indicates a parochial-subject type of the political culture, when the citizens evaluate personalities rather than policies and programs of the political institutions. It also hinders the establishment of parliamentary democracy, which relies on the citizens informed consideration of the policy and the program of the political parties in power, rather than on the leaders in office.

\footnotetext{
${ }^{31}$ The next parliamentary election took place in the spring 2006.

${ }^{32}$ According to World Bank report, GDP increase was higher during the Yanukovich years in cabinet (12.1\%), in comparison to the period of Tymoshenko' premiership (2.7\%). World Bank 14 January 2007 <http://siteresources.worldbank.org/UKRAINEEXTN/Resources/Macro_update_eng.pdf >.
} 


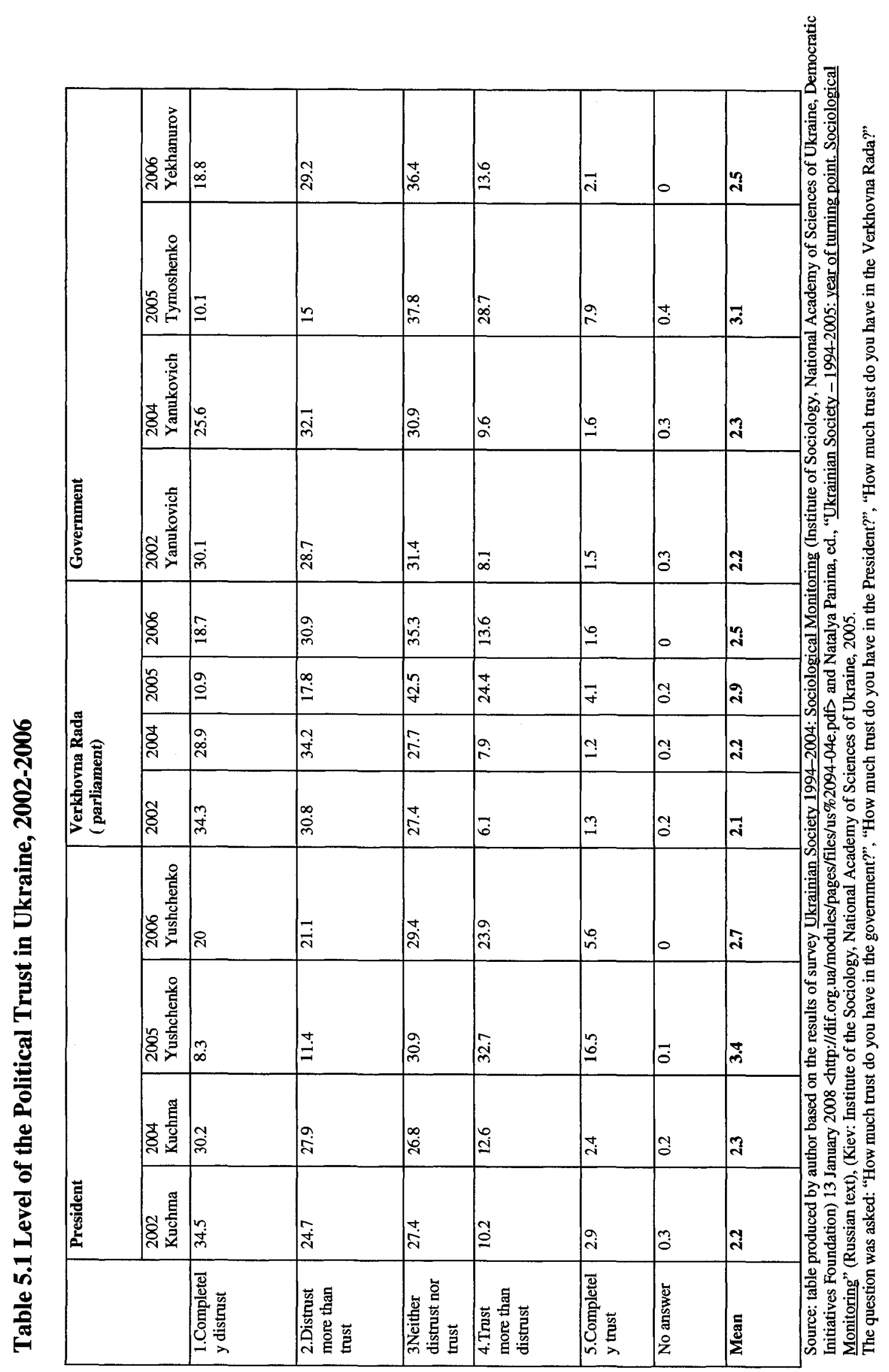


Another indicator of citizens' attitude towards their political system is their feeling about belonging to their country or "national pride as the general dimension of system affect.,"33 If the citizens of a country believe in the state and trust its institutions they will have a more positive feeling towards their citizenship and nationality. In Ukraine's case, however, as Figure 5.2 shows, in 2003 the percentage of the population that feels absolutely proud to be Ukrainian was only $6.2 \%$, the smallest of five groups classified. The percentage of the population that chose the "neither proud nor not" option is the largest group throughout the period between 2002 and 2006, at $40.8 \%$ of the population. For comparison, in established democracies such as the USA, Canada and the UK, the percentage of the population who are proud to be citizens of the country is $72.2 \%, 66.6 \%$ and $49.8 \%$ respectively. ${ }^{34}$

Dramatic changes in peoples' attitude towards citizenship occurred after the Orange revolution in 2005 . The percentage of the population that felt "very proud" to be a Ukrainian citizen increased from $7.7 \%$ in 2004 to $15.3 \%$ in 2005 with the largest increase seen among youth, where the percentage of those that felt "very proud" increased from $5.7 \%$ in 2004 to $11.3 \%$ in 2006. The timing of the Orange revolution positively correlated with an increase in the citizens' favorable perception of belonging to their country. However, this short period of increase was followed by a decrease in 2006 , after the dismissal of the Tymoshenko government in the summer of 2005. Ukrainians that felt 'very proud' of their citizenship decreased from $15.3 \%$ in 2005 to $11.9 \%$. This corresponded to an increase in the expression of those that felt "not very proud" or "not at

\footnotetext{
${ }^{33}$ Almond and Verba 65.

${ }^{34}$ World Value Survey 5 December 2007 < http://www.jdsurvey.net/bdasepjds/QuestionCrosstab.jsp>.
} 
all" which increased from $9.7 \%$ in 2005 to $12.5 \%$ in 2006 and from $5.2 \%$ in 2005 to $7.1 \%$ in 2006.

\section{Figure 5.2}

The Feelings toward Citizenship in Ukraine,2002-2006

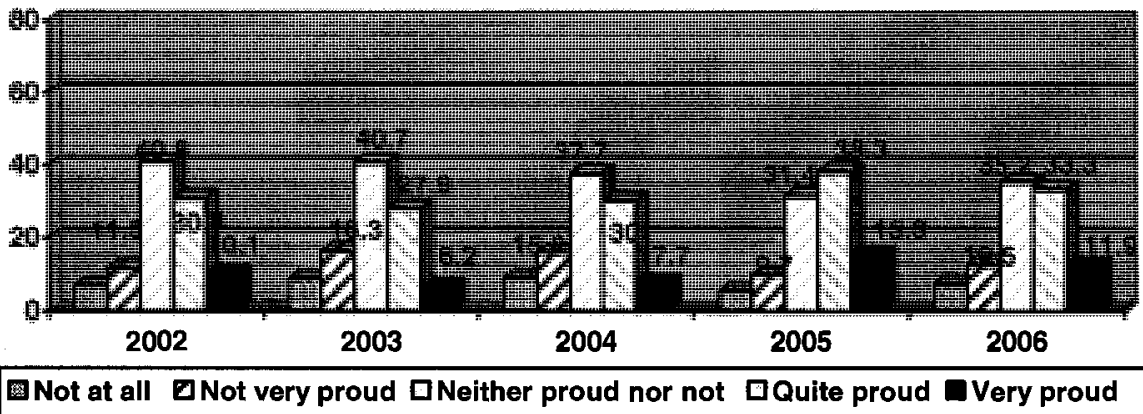

Source: graph produced by author based on the results of survey Ukrainian Society 1994-2004: Sociological Monitoring (Institute of Sociology, National Academy of Sciences of Ukraine, Democratic Initiatives Foundation) 03 January $2008<\mathrm{http}$ //dif.org.ua/modules/pages/files/us\%2094-04e.pdf $>$ and Natalya Panina, ed., "Ukrainian Society - 1994-2005: year of turning point. Sociological Monitoring" (Russian text), (Kiev: Institute of the Sociology, National Academy of Sciences of Ukraine, 2005 The question was asked as "Are you proud to be a Ukrainian citizen?

While it is suggested that the Orange revolution positively changed citizens' perceptions towards belonging to the country, the majority of the citizens do not have a high level of pride in their citizenship. If the majority of the citizens are not proud to be citizens of the country in which they live, then they may feel a greater detachment from the problems of their society. They also will be less active in their attempts to change the policies of the government. A government faced with a passive citizenry, is less likely to be held accountable for its actions, and therefore may be more susceptible to corruption. These two patterns reinforce each other in a negative feedback cycle, where the governments' perceived unresponsiveness leads to lack of identification which undermines accountability. 


\subsection{The Orientation towards Others in the Political System}

\subsubsection{The level of trust among citizens}

Trust in one's fellow citizens can have an impact on their ability to cooperate with each other. As Robert Dahl stated "Trust is obviously related... to the capacities of people for engaging freely and easily in cooperative action." 35 The higher the trust among citizens in their compatriots, the greater the possibility for political cooperation. Thus, to cooperate with each other increases the likelihood that the political opposition will succeed in mobilising the electorate, in turn increasing the level of the democracy in a country. "Trust may also reduce political conflicts, as they become more manageable through an increased willingness to making compromises, thereby strengthening political stability., 36

In Ukraine, the level of trust among citizens is low (see Table 5.2); only 6.7\% (2004) of the population say that they completely trust their compatriots and only $7.2 \%$ of the population who completely trust their colleagues (2004). The majority of the population "neither trust nor distrust" their fellow citizens, which indicates their uncertainty combined with apathy. Moreover, $45.2 \%$ of the population disagrees with the statement that they can trust most people ${ }^{37}$. The increase of $9.5 \%$ in the level of trust in 2005 after the Orange revolution was followed by a decrease of $2.5 \%$ in 2006 , the year Orange team failed to create a coalition government.

\footnotetext{
${ }^{35}$ Robert A. Dahl, Polyarchy, Participation and Opposition (New Haven : Yale UP, 1971)152.

${ }^{36}$ Jan-Erik Lane and Svante Ersson, ed., Culture and Politics, A comparative Approach (Aldershot: Ashgate, 2002)287.

${ }^{37}$ The question was asked as "Are you agree or disagree with idea below that you can trust most people?"
} 
Table 5.2 Level of Interpersonal Trust in Ukraine, 2002-2006

\begin{tabular}{|c|c|c|c|c|c|c|c|c|c|c|c|c|}
\hline & \multicolumn{4}{|c|}{ Family and relatives } & \multicolumn{4}{|c|}{ Compatriots } & \multicolumn{4}{|c|}{ Colleagues } \\
\hline & 2002 & 2004 & 2005 & 2006 & 2002 & 2004 & 2005 & 2006 & 2002 & 2004 & 2005 & 2006 \\
\hline 1.Completely distrust & 1.1 & 1.9 & 0.9 & 1.1 & - & 5.1 & 2.6 & 2.9 & 4.3 & 4.4 & 3.2 & - \\
\hline $\begin{array}{l}\text { 2. Distrust more than } \\
\text { trust }\end{array}$ & 1.6 & 2.8 & 1.3 & 1.4 & - & 12.9 & 9.5 & 8.3 & 9.3 & 11.6 & 9.7 & - \\
\hline $\begin{array}{l}\text { 3. Neither distrust nor } \\
\text { trust }\end{array}$ & $\overline{5.3}$ & $\overline{4.6}$ & 4.2 & 4.2 & - & 42.3 & 38.7 & 42 & 33.7 & 36.3 & 32.1 & - \\
\hline $\begin{array}{l}\text { 4.Trust more than } \\
\text { distrust }\end{array}$ & 28.0 & 30.2 & 34.8 & 33.7 & - & 32.8 & 42.3 & 39.8 & 40.2 & 39.9 & 46.2 & - \\
\hline 5.Completely trust & 63.9 & 60.4 & 58.7 & 59.6 & - & 6.7 & $6 . \overline{8}$ & 7 & 11.3 & 7.2 & 7.7 & - \\
\hline No answer & 0.2 & 0.1 & 0.1 & 0 & $=$ & 0.2 & 0.2 & 0 & 1.1 & 0.6 & 1.1 & - \\
\hline Mean & 4.5 & 4.4 & 4.5 & 4.5 & - & 3.2 & 3.4 & 3.4 & $\mathbf{3 . 5}$ & $\mathbf{3 . 3}$ & $\mathbf{3 . 5}$ & - \\
\hline
\end{tabular}

Source: table produced by author based on the results of survey Ukrainian Society 1994-2004: Sociological Monitoring (Institute of Sociology, National Academy of Sciences of Ukraine, Democratic Initiatives Foundation) 03 January $2008<$ http://dif.org.ua/modules/pages/files/us\%2094-04e.pdf> and Natalya Panina, ed., "Ukrainian Society - 1994-2005: year of turning point. Sociological Monitoring" (Russian text), (Kiev: Institute of the Sociology, National Academy of Sciences of Ukraine, 2005. The questions were asked as, "How much trust do you have in your compatriots", "How much trust do you have in your colleagues?' and "How much trust do you have in family and relatives?"

In summary, levels of trust between citizens in Ukraine, as observed in the survey, are low. Only family and relatives are completely trusted by Ukrainians, with as high as $60.4 \%$ of the population responding that they completely trust their close relatives.

\subsubsection{Political identifications}

The low level of interpersonal trust among Ukrainian citizens can have influence on the level of citizens' involvement in non-governmental organisations. As Figure 5.3 indicates, a majority of the population, $83.8 \%$, did not belong to any organizations at all in 2004 . Only $0.7 \%$ of the citizens were involved in a public organization and $0.4 \%$ of the population were the members of trade unions. The highest percentage of citizens' involvement is observed in religious organisations, $4.2 \%$. This low level of participation in the civil and political organisations is characteristic of a parochial-subject political 
culture, where dissatisfied citizens dissociate themselves from the political process instead of taking active part in it. $^{38}$

\section{Figure 5.3}

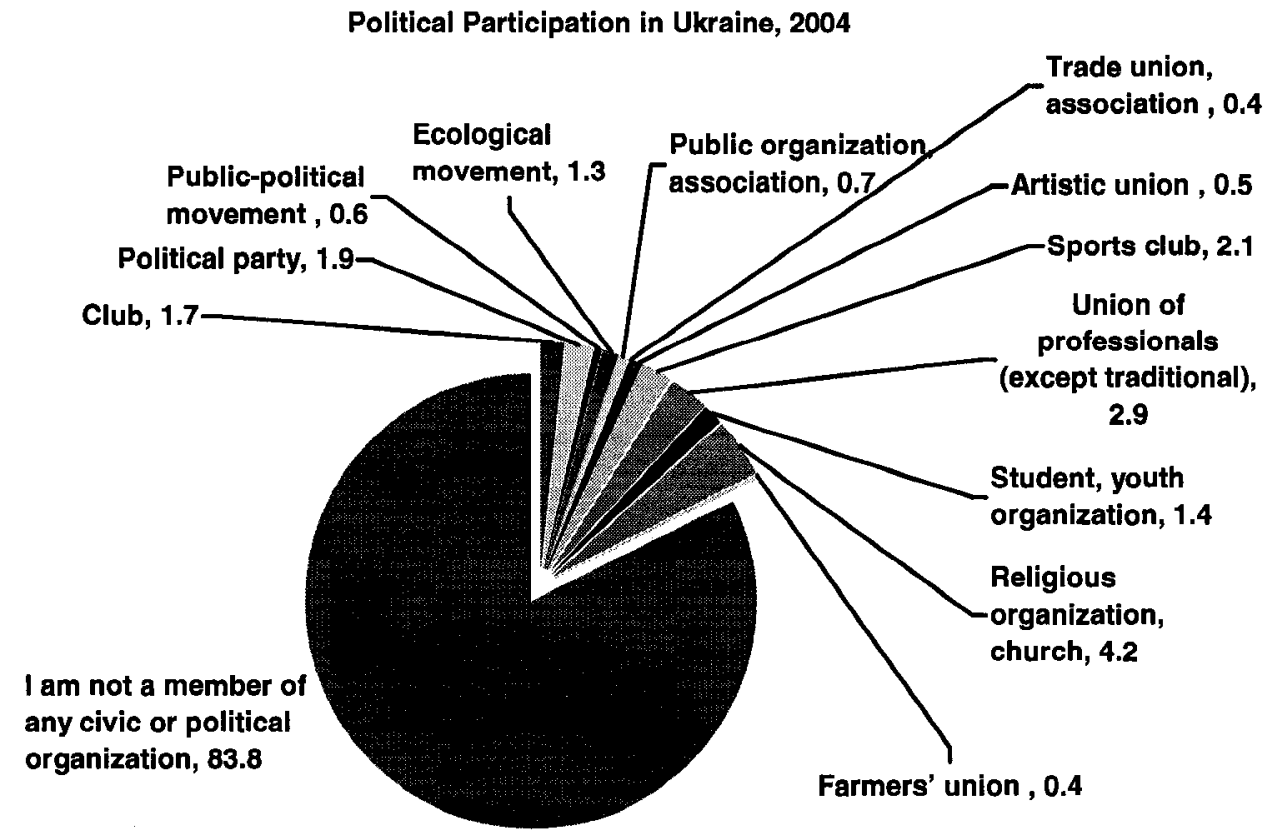

Source: chart produced by author based on the results of survey Ukrainian Society 1994-2004: Sociological Monitoring (Institute of Sociology, National Academy of Sciences of Ukraine, Democratic Initiatives Foundation) 03 January 2008 <http://dif.org.ua/modules/pages/files/us\%2094-04e.pdf> The question was asked as "Which civil or political organization are you a member of?"

This alienation was not appreciable altered even after the Orange revolution, which was notable for the high level of citizens' involvement. $4.8 \%$ of Ukrainians indicated that they took part in Kiev actions and $12.9 \%$ took part in the protest actions in the other cities. $^{39}$ In the 2005 survey, the year after the Orange revolution, $83.7 \%$ of citizens admitted not belonging to any civic and political organization.

\footnotetext{
${ }^{38}$ According to the World Value Survey, the percentage of the population that are member of labor unions and professional associations in Canada, the UK and the USA is at the level of 32.3\%,9.8\% 41.6\% respectively. World Value Survey 25 January 2008 <http://www.jdsurvey.net/bdasepjds/QuestionCrosstab.jsp>.

${ }^{39}$ The question was asked: Did you participate in the protest actions during the «orange revolution»? The answers were coded as follow: 1.Participated in the protest actions in Kyiv. 2. Participated in another city/ village. 3. aided the protestors (with food, clothes, money). 4. Did not participate. 5. No answer.
} 
Ukrainian citizens also showed an absence of strong political identification. From the Figure 5.4 we can see that almost half of the population, $46 \%$ do not identify themselves with any political movement or ideology, do not understand them or have not decided yet. ${ }^{40}$ Thus the political parties, including the parties of Orange team can not count on the stable support of an informed electorate: Moreover, it is more difficult for parties to keep their electoral promises after the election, because their programs are not developed and defined in relation to a clear constituency; rather they are more populist in order to attract the largest segment of a volatile electorate.

Figure 5.4

Political Identification in Ukraine, 2004

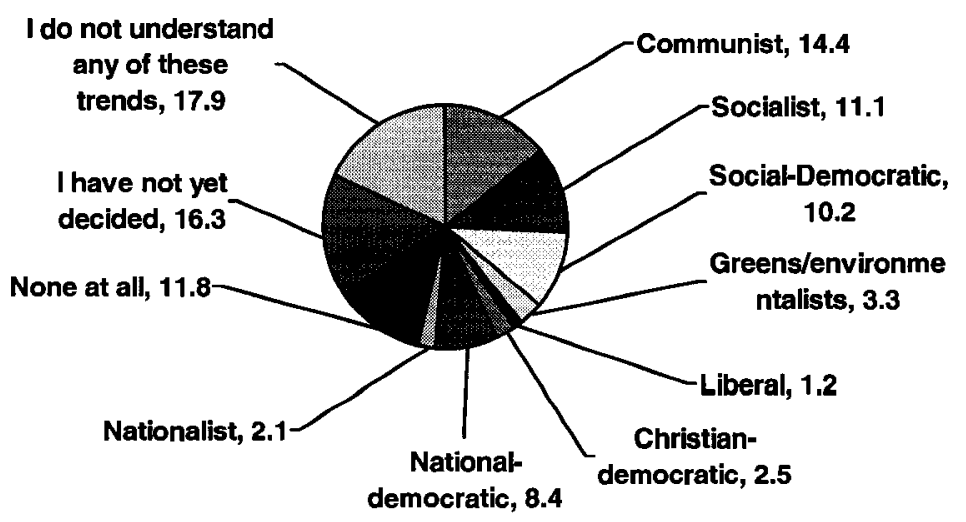

Source: chart produced by author based on the results of survey Ukrainian Society 1994-2004: Sociological Monitoring (Institute of Sociology, National Academy of Sciences of Ukraine, Democratic Initiatives Foundation) 60, 03 January $2008<$ http://dif.org.ua/modules/pages/files/us\%2094-04e.pdf> The question was asked as "Within the political arena there are more-or-less independent movements that frequently develop. The following are several of such movements. Please choose one that is most important to you"

\footnotetext{
${ }^{40}$ For comparison in Canada, UK and USA the percentage of the population that do not identify themselves with any political movement and ideology it at the level of $13.8 \%$ in Canada, $18.9 \%$ in UK and only $5.4 \%$ in USA. World Value Survey 25 January 2008 $<h t t p: / / w w w . j d s u r v e y . n e t / b d a s e p j d s / Q u e s t i o n M a r g i n a l s . j s p>$.
} 


\subsection{Orientations towards Own Political Activity}

\subsubsection{Political awareness}

The level of general political awareness in the country influences the ability of citizens to be politically active and to be involved in political and civil organisations. The more aware citizens are, the more politically active they are likely to be. In Ukraine, as Figure 5.5 shows, the percentage of the population who believe that they have a sufficient level of political knowledge is $21.42 \%$ (year 2004). In contrast, $48 \%$ of the population admitted that they possess an insufficient level of political knowledge. This contrast existed even during the political crisis in the country and during the Kuchmagate scandal. ${ }^{41}$ In 2005, the year after the Orange revolution, the percentage of respondents that said they possessed a sufficient level of political knowledge increased to $27.22 \%$. However as many as $72.56 \%$ of the citizens said they either had insufficient political knowledge or said it was "difficult to say". This tendency continued in 2006 when $37.16 \%$ of respondents said that they possessed an insufficient level of political knowledge. Thus the presence of a politically active citizen who possesses a high level of political awareness, which is a core of feature a developed democracy, is largely absent from Ukraine.

\footnotetext{
${ }^{41}$ The Kuchmagate scandal started in the fall of 2000, when President Kuchma was accused of the envolmnent in the disappearance and murder of journalist Georgiy Gongandze. For an account of the Kuchmagate scandal see Andrew Wilson, Ukraine's Orange Revolution (London: Yale University Press, 2005).
} 


\section{Figure 5.5}

Level of Political Know ledge in Ukraine, 2000-2006

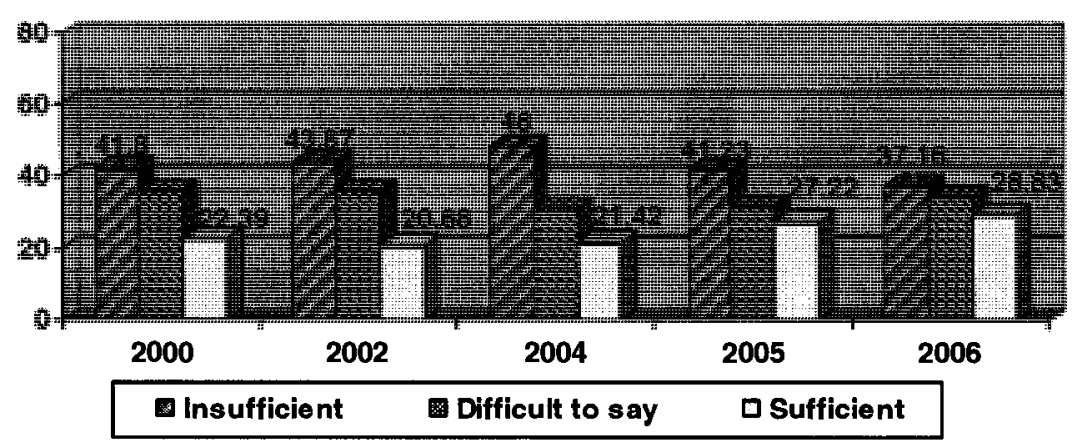

Source: graph produced by author based on the results of survey Ukrainian Society 1994-2004:

Sociological Monitoring (Institute of Sociology, National Academy of Sciences of Ukraine, Democratic Initiatives Foundation) 20 December 2007<http://dif.org.ua/modules/pages/files/us\%2094-04e.pdf $>$ and Natalya Panina, ed., "Ukrainian Society - 1994-2005: year of turning point. Sociological Monitoring" (Russian text), (Kiev: Institute of the Sociology, National Academy of Sciences of Ukraine, 2005. The question was asked "Do you feel that you sufficiently possess contemporary political knowledge?",42

\subsubsection{Political efficacy}

An effective political opposition requires efficacious citizens who can provide the support for parties of the political opposition. Efficacious citizens also assert their rights in their relations with the government helping to make the government more accountable. "A major element of a democratic political orientation is the belief that one has some control over political elites and political decisions."

In Ukraine, the level of the political efficacy, as Figure 5.6 shows, varies. In 2002 , the year of the parliamentary election, only $7.3 \%$ of population were in agreement with the proposition that they would take action against a government decision that encroached on peoples' interests, simultaneously $65.8 \%$ of the population agreed that they would not take any action against such a government decision. ${ }^{44}$ In 2004 , the year

\footnotetext{
${ }^{42}$ This question is the English translation by the Democratic Initiatives Foundation, which published the English version of the report. It suggested that proper translation would be "f.6 In your opinion do you have any deficiencies in the following subjects? f. 6.11. Contemporary political knowledge".

${ }^{43}$ Almond and Verba 299.

${ }^{44}$ Panina 17.
} 
of the Orange revolution, $69 \%$ of those surveyed agreed with the statement that they would not take any action against government decision, while only $6.2 \%$ agreed to take action. The Orange revolution was held by many as strong evidence of citizens' efficacy in Ukraine, yet it did not significantly change the citizens' perception of their political efficacy. As Figure 5.6 shows, in 2005 there were marginal increases measured in citizens' efficacy. A majority of the population, $57 \%$ agreed with the statement that they would not take any actions against a government decision even if it encroached on their interests while only $9.4 \%$ agreed that they would take action. In 2006 , the year of the parliamentary election, $63.2 \%$ of the population chose the same option with only $8.2 \%$ of the population agreed to take some action.

\section{Figure 5.6}

\section{Political Eficacy in Ukraine, 2002-2005}

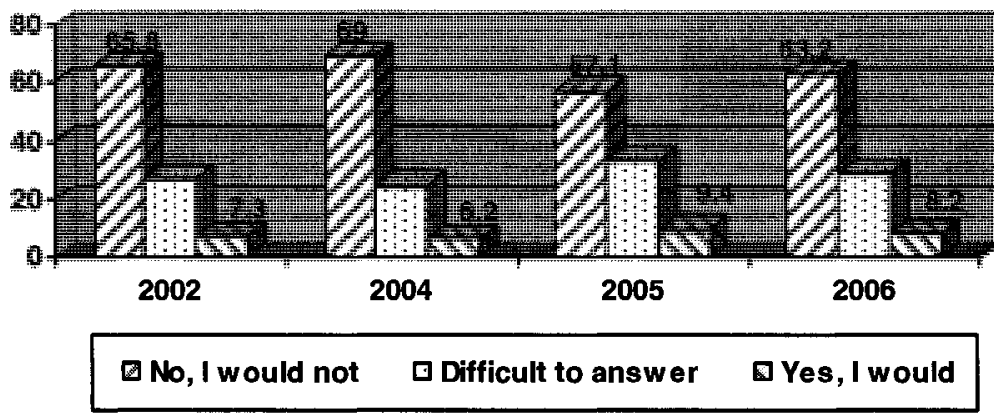

Source: graph produced by author based on the results of survey Ukrainian Society 1994-2004: Sociological Monitoring (Institute of Sociology, National Academy of Sciences of Ukraine, Democratic Initiatives Foundation) 20 December 2007<http://dif.org.ua/modules/pages/files/us\%2094-04e.pdf $>$ and Natalya Panina, ed., "Ukrainian Society - 1994-2005: year of turning point. Sociological Monitoring" (Russian text), (Kiev: Institute of the Sociology, National Academy of Sciences of Ukraine, 2005. The question was asked as "If Ukrainian government made a decision that encroached on peoples' interest, would you take some kind of action against this decision?"

This passiveness among the Ukrainian citizens combines with the belief that they do not have any influence on the political process in the country. As Figure 5.7 shows as high as $40.2 \%$ of respondents believe that the mafia and criminal elements have the greatest 
influence on state activity with the leaders of the political parties taking at third place with $25.9 \%$ and trailing business leaders who have $27.0 \%$. Thus the government is less accountable to the public, because it is free from public control. "If decision makers believe that the ordinary man could participate - and they certainly are not entirely cut off from the dominant social beliefs- they are likely to behave quite differently than if such a belief did not exist.",45

\section{Figure 5.7}

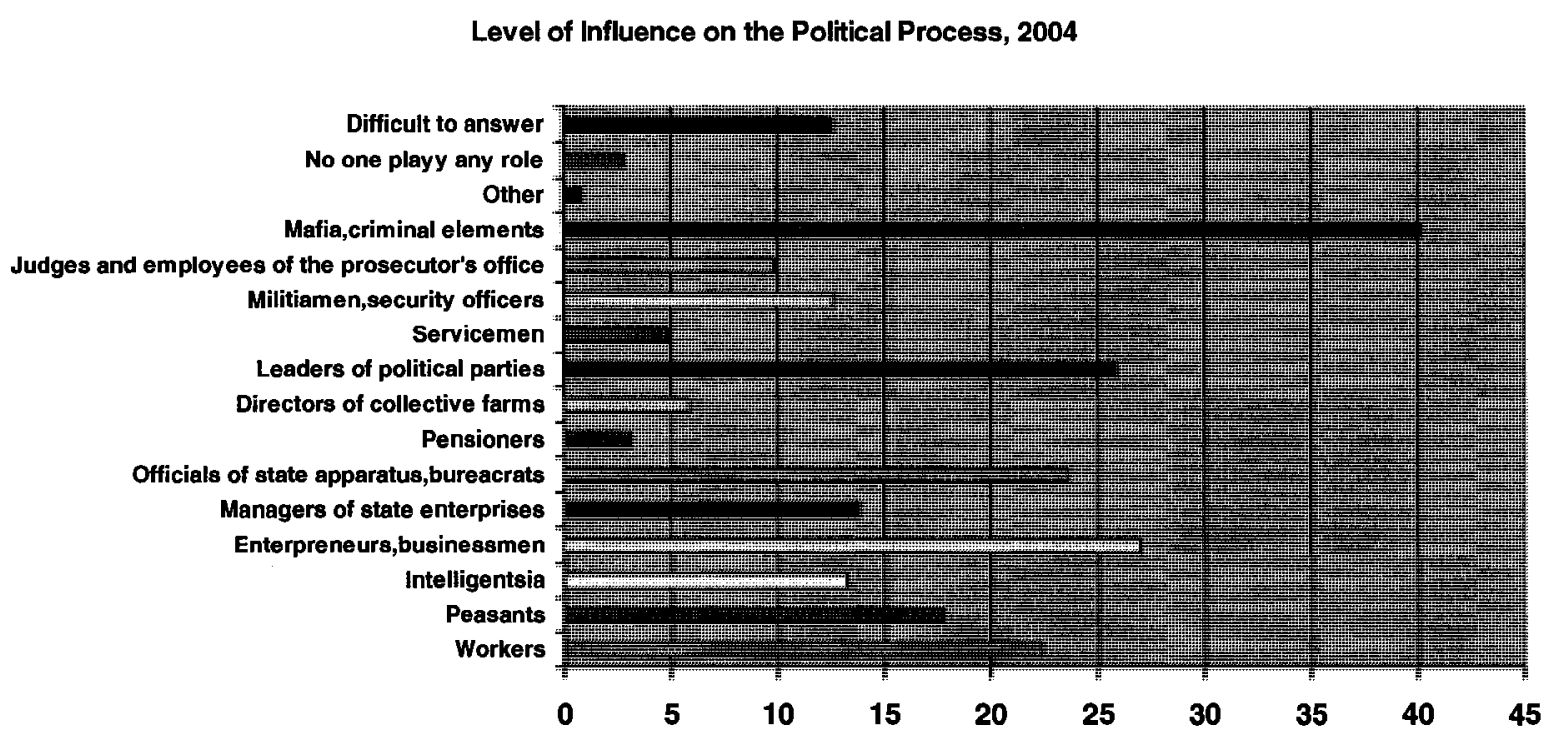

Source: graph produced by author based on the results of survey Ukrainian Society 1994-2004: Sociological Monitoring (Institute of Sociology, National Academy of Sciences of Ukraine, Democratic Initiatives Foundation) 20 December 2007<http://dif.org.ua/modules/pages/files/us\%2094-04e.pdf $>$. The question was asked as "In your opinion, which of these social groups plays a powerful role in shaping the Ukrainian state? (mark all applicable answers)

\subsection{Age and Education as Predictors of the Political Culture}

From the above we can conclude that the mass political culture of Ukrainian society represents a parochial-subject type of political culture, whose main characteristics are a high level of distrust in political institutions together with a low level of political

\footnotetext{
${ }^{45}$ Almond and Verba 139.
} 
activity among citizens. However, this does not explain the reason for this type of the political culture and which factors have the greatest influence on people's opinion. We can hypothesize that the more educated people would have a higher level of political knowledge and would be more active and thus would have a higher level of political efficacy. Likewise we hypothesize that the younger citizens will show a higher level of political efficacy than the older generation. To test these hypotheses an SPSS regression analysis of the relations between citizens' opinion and their age and education is employed. ${ }^{46}$ The results are presented below. As Table 5.3 shows, age is a better predictor of people's attitudes than education.

\begin{tabular}{|c|c|c|c|c|c|c|}
\hline \multirow[b]{2}{*}{ Trust in the compatriots } & \multicolumn{6}{|c|}{$\begin{array}{l}\text { Independent variables } \\
\text { Education }\end{array}$} \\
\hline & $\begin{array}{l}\text { Coef. B } \\
.137\end{array}$ & $\begin{array}{l}\text { R square } \\
.011\end{array}$ & $\begin{array}{l}\text { Sig } \\
.000\end{array}$ & $\begin{array}{l}\text { Coef. B } \\
-.056\end{array}$ & $\begin{array}{l}\text { R square } \\
.005\end{array}$ & $\begin{array}{l}\text { Sig } \\
.002\end{array}$ \\
\hline Trust in the relatives & -.019 & .000 & .501 & .025 & .001 & .144 \\
\hline $\begin{array}{l}\text { Political knowledge } \\
\text { Activity against the government } \\
\text { How proud to be Ukrainian citizen }\end{array}$ & $\begin{array}{l}.225 \\
. .054 \\
.093\end{array}$ & $\begin{array}{l}.018 \\
.004 \\
.004\end{array}$ & $\begin{array}{l}.000 \\
.005 \\
.007\end{array}$ & $\begin{array}{l}-.029 \\
.028 \\
-.037\end{array}$ & $\begin{array}{l}.001 \\
.003 \\
.002\end{array}$ & $\begin{array}{l}.219 \\
.018 \\
.074\end{array}$ \\
\hline Trust in the president & -.043 & .001 & .228 & .011 & .000 & .608 \\
\hline Trust in the government & -.023 & .000 & .489 & .003 & -.001 & .892 \\
\hline Trust in the parliament & .009 & .000 & .777 & -.009 & .000 & .625 \\
\hline Believe in the strong leadership & -.018 & .000 & .471 & .030 & .002 & .044 \\
\hline
\end{tabular}

Coeff. B - unstandardized coefficient of regression

$\mathrm{R}$ Square- the fraction of variance in the dependent variables that is explained by changes in independent variables Sig (1-talied) - level of statistical significance of the relations between two variables. The relations are statistically significant at $\mathrm{Sig} \leq 0.05$

Source: table produced by author based on results of the regression analysis which was ordered at the Institute of the Sociology, National Academy of Science of Ukraine.

The strongest relations are observed between the level of the political knowledge and age. Higher levels of political knowledge are positively correlated with older age

\footnotetext{
${ }^{46}$ The regression analysis was ordered at the Institute of the Sociology, National Academy of Science of Ukraine on the basis of the result of the Sociological Monitoring, prepared on 13 December, 2007. The sample size was 1800 respondents in all regions of Ukraine. The standard error of the estimate is $3.0 \%$. The age was coded as follows: 1- young group, 15-29 2- Middle age 30-54, 3 - senior age, 55 and older. Education was coded as follows: 1 - Primary or incomplete secondary 2-General secondary 3-Spesialized secondary (technical college) 4- incomplete higher (couple years of university) 5- higher ( BA, MA and $\mathrm{PhD})$
} 
$\mathrm{B}=.225$. However, from the $\mathrm{R}$ square $=.018$ we can conclude that changes in age explain only $1.8 \%$ of changes in the level of the political knowledge, which is not a high indicator of variance. Age is also positively correlated with the level of trust in compatriots, $\mathrm{B}=.137$. The relations between the variable "age" and the "possibility to take actions against the governments decision" are negative, $\mathrm{B}=-.054$, that with the increase in age the possibility to take actions against the government decrease.

As for the influence of the level of education on the level of political trust and on political activity, higher levels of education are positively correlated with higher levels of political activity, $\mathrm{B}=.028$, and a desire for strong leadership, $\mathrm{B}=.030$. Coefficient $\mathrm{B}=-$ .056 for the relation between the level of education and trust in compatriots indicates that relations are negative, thus higher education is associated with a lower level of trust. From this it suggested that an assumption can be made that the highly educated leaders of parties of the Orange team would have a lower level of trust in comparison to lower educated group and as a result would be less willing to cooperate with each other. ${ }^{47}$ However from $\mathrm{R}$ Square $=.005$ we can see that education explains less than $0.5 \%$ of variance in citizens trust in compatriots. Thus the level of trust depends not only on demographic characteristic of citizens such as age and education, but possibly on other factors. ${ }^{48}$

\footnotetext{
${ }^{47}$ According to the Central electoral commission of Ukraine from 7595 candidates that were registered in 2006 election, $90.93 \%$ had high level of formal education (Bachelor and higher). Central Electoral Commission of Ukraine 16 January $2008<\mathrm{http}$ ://www.cvk.gov.ua/vnd2006/w6p001.html>. ${ }^{48}$ According to study by William Mishler and Richard Rose "aggregate corruption had the strongest effect on interpersonal trust" in the post-communist societies. See William Mishler and Richard Rose, "What are the Origins of Political Trust?: Testing Institutional and Cultural Theories in Post-communist Societies," Comparative Political Studies 34.1(2001):30-62, 53.
} 


\subsection{Mass Political Culture and the Political Elite}

The mass political culture differs from the political culture of the elite, however; it has influence on the behaviour of elites. In the case of Ukraine it has following consequences.

First, the low level of the political awareness, political identification and political participation underlies a high level of electorate volatility. When the majority of the population does not possess a high level of the political knowledge, do not understand the meaning of the political ideology and do not participate in political organizations, they make their choice during the campaign. Without having a stable base of support in the electorate, the political parties campaign on the promises that are difficult to achieve but help to be elected. This situation also allowed the parties of the Orange team to campaign on the promises of a future coalition government during the 2006 election, which was electorate's expectation. However the Orange team did not have a policy and program for the future government.

Second, the general low level of interpersonal trust among Ukrainian citizens hinders their cooperation in joint activity. The absence of the social interaction between the citizens leads to a low level of political activity that decreases accountability. Knowing that a majority of the citizens will not take any action against the government, the parties have less need to keep their electoral promises. This also contributed to the parties of Orange team being less concerned about their accountability which meant there was less incentive to cooperate among them after the 2006 election. Upon election to parliament for a fixed term of 5 years (Rada term), the leaders of Orange team were less concerned with representing the interests of their electorate than with access to power. 
As noted earlier, Ukrainians expressed a preference for a strong leader over strong laws. By this measure, an electoral win meant access to power, and the lack of trust in compatriots meant that struggle for power continued after the elections among the members of Orange team, at the expense of collaboration to run the government.

\subsection{Conclusion}

After the analysis of the specifics of mass political culture in Ukraine and its influence on the political process as well as the effectiveness of the parties of opposition some conclusions can be drawn.

First, the mass political culture of Ukraine represents the parochial-subject type of the political culture. A high level of distrust in political institutions is combined with a low level of impersonal trust that led to the low levels of political participation. In combination with low level of the political awareness this resulted in the low level of the political efficacy. The modern demographic composition of Ukraine includes a high percentage of citizens older than 60 years of age, who are heavily influenced by Soviet political culture. Its main characteristics are desire for strong leadership, the personalization of political institutions and weak participation in the political process is still present in today Ukraine.

Second, a parochial-subject mass political culture has an impact on the behavior of the political elite. This may help to explain the failure of the parties of Orange team to create a coalition government after the 2006 election. The absence of an expectation that citizens would act if they fail to keep promises may have made the Orange team leaders feel less compelled to find solutions to their internal disagreements. If citizens' efficacy 
was higher it could be speculated that this could have influenced the members of Orange team in the direction of cooperation.

Third, age and education, two of the main predictors of citizens' opinions in developed democracies, explain only a small part of the variance in the level of political trust and political activity in Ukraine. However, young age is positively correlated with a higher level of political activity. Thus the younger citizens are more involved in the political process and this can increase the parties' support, including the parties of Orange team. As for the level of education, it is negatively correlated with trust in compatriots. The most highly educated groups in Ukraine show more distrust in their compatriots. This fact may also provide an explanation for the failure of the parties of the Orange team to create a coalition government. Being more highly educated than the majority of the population, they are likely to exhibit higher levels of distrust. As a result the leaders of the Orange team could not collaborate in sharing power after the election, which require a high level of trust in each other.

Finally, positive changes in citizens' attitudes after the Orange revolution may indicate that Ukraine's political culture is in the midst of transformation from being parochial-subject political culture to becoming a participant type. The slight increase in the citizens' belief in their ability to change the future of their country after the Orange revolution and a higher level of trust in the government and compatriots suggest that the mass political culture of Ukraine's citizens is moving towards the participant type of political culture. However, due to the lengthy time required for implementation of a new system of peoples' values and beliefs, these changes will not been apparent for some time. 


\section{CONCLUSION}

Despite their electoral success during the Orange revolution, Ukrainian opposition parties, which were unified in opposing the Yanukovich victory at the polls, failed to create a coalition government after the Orange revolution and subsequently after the 2006 parliamentary election. Among the four sets of variables that were tested in the thesis, all four had influence on the failure of Orange team to create the coalition government. The political party system, the constitutional structure and the political culture are the most influential variables. Thus the basic hypothesis, that the parties of Ukrainian political opposition were successful in defeating the government in the 2004 presidential election but they were not effective because they could not create an alternative government due to the specifics of the institutional and civic framework in Ukraine, has been supported.

In the first chapter of the thesis, which considered the existing theory on the subject of political opposition and its effectiveness, four main factors were identified as important for the study of the political opposition in Ukraine. Using the works of Robert Dahl and Ludgeme Helms, together with typologies developed by Leonard Shapiro and Gordon Skilling (these specifically on political opposition in one party states), the author concluded that the effectiveness of the political opposition in Ukraine are influenced by : the political party system, the constitutional structure, the electoral system and the political culture.

The second chapter analysed the party system in Ukraine and confirmed that it was relevant to the Orange team's failure to form an effective political opposition subsequent to its electoral success. The multi-party political system in Ukraine is not supportive of the formation of a cooperative type of political opposition, the only type 
that is effective in a situation where there are multiple political parties. The high number of political parties, their short duration and the non-mass character of their origin reveals that Ukraine's party system is uninstitutionalized. The origin of political parties in Ukraine, including the parties of the Orange team, shows that they are not mass political parties. Rather they are cartel parties or "catch all" parties, which are based around leaders, within the parliament or created as elections loom. Their non-mass character led to an absence of stable partisan voters and to weak support from social groups. This resulted in a high level of electorate volatility and an open structure of party competition. With a high number of political parties to compete in the election and an absence of partisan voters the outcome of the election is unpredictable.

It also prevented the collaboration of the political parties of the Orange team before and after the 2002 and 2006 elections. An analysis of the texts of the electoral programs of the parties and blocs of the Orange team showed that they did not have a common party program and policy for governance. Thus the parties did not satisfy the requirement for cooperation which is necessary in order to create a coalition government. The Orange parties based their campaigns on their leaders' public recognition. Their main goal was to be elected to the Rada instead of introducing a coherent program by which a future government could be administered. Moreover the lists of the candidates of the parties and the blocs of the Orange team, which included many members of the previous regime, was contrary to the requirement to have alternative personnel for the for the future government. The blocs and parties in effect offered a continuation of the previous regime under a new banner. 
Chapter Three of the thesis analysed the text of the Constitution of Ukraine as it related to the subject of the separation of powers in Ukraine. The most significant finding of this chapter is that the Constitution of Ukraine does not provide a clear separation of powers between the legislative and the executive branches of government, which is an important condition for a competitive and effective opposition. In the presidential-parliamentary system of government that existed when the parties of the future Orange team were first elected to the Rada in the 2002 election, the role of the head of state and the head of the executive resided with the president. The president was directly elected for a fixed term of five years and had unlimited power to appoint the cabinet without parliament's involvement. Parliament and the parties that it comprised did not have influence on the formation of the government nor did they possess the ability to dismiss it. The opposition parties, which were elected to the Rada in 2002, did not have power over the cabinet, which was subordinated to President Kuchma, and as result they were not effective in their opposition role.

It was concluded that the parties of the political opposition were successful in the presidential election in 2004 because of the personalisation of the presidential campaign in Ukraine. The opposition parties collaborated in order to support a united presidential candidate from the opposition, Viktor Yushchenko. Their motivation was to secure access to the unlimited power of the post of the president. This suggested that the opposition victory was not a victory of policy and program; it was a victory over the personality of Kuchma and his would be successor, prime-minister Viktor Yanukovich. Moreover, the non-party character of the post of the president was attractive to many politicians. It also was a reason for the failure of the Orange team to create a 
coalition government. After his election, non-party member President Yushchenko did not feel a need for party support. This was demonstrated when he failed to support his bloc during the 2006 parliamentary election. This led to decreased electoral support for the bloc Our Ukraine in that election and it increased its dependence on the other parties. If the president had been an active representative of the political bloc Our Ukraine, he would have more interest in collaborating with the parties of the bloc and with the parliament where they served.

An analysis of the changes to the constitution in 2004 showed that those amendments did not resolve the problem of the dual executive in Ukraine. The parliamentary-presidential system gave parliament the power to appoint and dismiss the government; however it also left the president with significant authority that allowed him to influence the work of the government. This led to conflict. The failure to form a coalition government after the 2006 election was attributable to conflict between President Yushchenko and potential Prime-Minister Tymoshenko and the authority of their respective offices of president and prime-minister. Without compromise, the leaders of the Orange team were not able to create a parliamentary majority after the election and therefore they failed to create a coalition government.

Chapter Four explored the role of the electoral system in the representation of the political parties in parliament. Using the Gallagher index of disproportionality to analyze the electoral formulas in effect for the 2002 and the 2006 parliamentary elections, respectively, it was confirmed that the mixed electoral system in 2002 did not allow for proportional representation of the opposition parties in parliament. A large number of the self-nominated and non-party member candidates in the SMD and the simple plurality 
formula had the effect of allowing the candidates to be elected with as little as $10 \%$ of the valid votes cast in certain districts. Testing of the single plurality formula revealed that it resulted in a higher level of disproportionality than the largest reminder Hare quota electoral formula for the distribution of seats for PR list. This meant that the opposition parties' portion of the SMD seats was less than their portion of the popular vote. Thus if the 2002 election had been decided within the parameters of an absolute proportional electoral system instead of the mixed electoral system, the proportional representation of the political parties would have been increased including the parties of the opposition, it is concluded that this would improve the parties' effectiveness.

The 2006 parliamentary election, the first after the Orange revolution, took place under a clear proportional representation closed party list electoral system with the nation wide threshold of inclusion of $3 \%$. The parties of the Orange team gained in total $41.93 \%$ of the vote nation wide that was translated to the majority of the seats in the Rada, 243 from 450 in accordance with the largest remainder Hare quota electoral formula. Notwithstanding this result, the Orange parties did not create the coalition government after the election. The parties' failure to create a parliamentary majority and a coalition government after the election was due to factors other than the electoral system.

Chapter Five contained the significant finding of the thesis. Analysis of data from two series of national surveys carried out between 1994 and 2005 suggested that the mass political culture of Ukraine society contributes to the ineffectiveness of the parties of the Orange team. The mass political culture in Ukraine represents the parochial-subject political culture; this delays the formation of an effective political opposition. The low 
level of interpersonal trust among Ukrainian citizens prevents their future cooperation in social action, including action against the government. This low level of political participation is combined with a low level of political awareness; accordingly, citizens play only a passive role in the political process. Citizens who do not participate in the political process have less of a belief in their ability to influence the government.

It seems likely that mass political culture has influenced the behaviour of the political elite, including the leaders of Orange team. When the government knows that citizens will not take action against government decisions that impugn citizens' interests, it becomes less accountable and responsive to the public. This contributed to the failure of the parties of the Orange team to create a coalition government after the Orange revolution and the 2006 election. After their success in the 2004 presidential election the leaders of the Orange team did not fulfill their campaign promise to create an effective coalition government. They were not able to collaborate and share power as required to form a coalition and this led to the dismissal of the Tymoshenko government in the summer of 2005. In the 2006 parliamentary election, the leaders of Orange team campaigned on promises to from a coalition government. However after being elected to the Rada for a fixed term of five years, the leaders of the Orange team did not fear punishment from the electorate for not keeping their electoral promises. For that reason they did not need to create a coalition government.

A bivariate correlation between the level of education and the political trust showed that a higher level of education in Ukraine is positively correlated with a higher level of interpersonal distrust. Thus the more educated leaders of the Orange team likely share this attitude of low trust in their colleagues and this may have prevented them from 
forming a united coalition government after the election, as this required a high level of interpersonal trust in other members.

Due to the breadth of the current project, the thesis had some limitations in its study of the political opposition in Ukraine and its effectiveness. The data on the political culture of the political elite, their system of values and beliefs was not available for this thesis. For that reason this thesis could not inquire into the differences between the mass political culture of society and the elite political culture. An to inability to access the full data set from the Institute of Sociology of Ukraine meant that the correlation between age, education and the level of political trust, political awareness and political efficacy was limited only to the demographic characteristics of respondents.

Second, during the studied time period, Ukraine made significant amendments to its constitution. The changes resulted in Ukraine's transformation from a presidentialparliamentary system to a parliamentary-presidential system. Ukraine's electoral system was altered from its mixed form to one of proportional representation. The parties of the Orange team were not effective under these changes; however it is possible that over time these changes may contribute to the creation of a more effective political opposition in Ukraine.

These limitations should be considered for future research on the effectiveness of the political opposition in Ukraine. It would be important to study the behaviour of the political elite, their system of values and beliefs and how it influences their political behaviour. Moreover it would be of interest to test the influence of the regionalisation of Ukraine and of its ethnographic composition on the structure of citizens' values and beliefs. This type of research would allow a more refined analysis of the role of political 
culture in promoting a higher level of interpersonal trust and thus a higher level of the political participation. This type of political culture is likely to bring about a higher level of political activity and political efficacy, key factors in realizing accountable and responsible government, which is the main goal of an effective political opposition. 


\section{BIBLIOGRAPHY}

\section{Primary sources:}

Deklaratsiya pro Derzhavnyy Suverenitet Ukrainy (Declaration of State Sovereignty of Ukraine) dated 16 July 1990 (VVR, 1990, No 31, art. 429)

$<$ http://zakon1.rada.gov.ua/cgi-

bin/laws/main.cgi?nreg=55\%2D12\&p=1172763330653063>.

Konstytutsiya Ukrainy (Constitution of Ukraine) Prosvita, Kyiv, 1996.

Zakon Ukrainy Pro Kabinet Ministriv Ukrainy (Law of Ukraine on Cabinet of Ministers of Ukraine) no. 65557994, dated 26 December 2006

<http://www.kmu.gov.ua/document/65557974/3акон\%20України\%20Про\%20Кабінет \%20Міністрів\%20України.doc>.

Zakon Ukrainy pro Reglament Verkhovnoyi Rady Ukrainy ( Law of Ukraine on the Rules and Procedures of Verkhovna Rada of Ukraine) no. 129/94, dated 27 July1994 $<$ http://zakon1.rada.gov.ua/cgi-

bin/laws/main.cgi?page=2\&nreg=129\%E0\%2F94\%2D\%E2\%F0>.

Zakon Ukrainy pro Reglament Verkhovnoyi Rady Ukrainy (Law of Ukraine on the rules and Procedures of Verkhovna Rada of Ukraine) no 3547-V, dated 16 March 2006, 15 August $2006<$ http://zakon1.rada.gov.ua/cgi-bin/laws/main.cgi?nreg>.

Zakon Ukrainy pro Vnesennya Zmin do Konstytutsii Ukrainy (Law of Ukraine on the changes to the Constitution of Ukraine), no 2222-IV, dated 08 December 2004 (VVR, 2005, No 2, art. 44) <http://zakon1.rada.gov.ua/cgi-bin/laws/main.cgi?nreg=2222$15>$.

Zakon Ukrainy pro Vybory Narodnykh Deputativ Ukrainy (Law of Ukraine on the Election of Peoples Deputies of Ukraine) no. 3623-XII, dated 18 November 1993 (VVR, 1993, No 48, art. 455) <http://zakon.rada.gov.ua/cgibin/laws/main.cgi?page=1\&nreg=3623-12>.

Zakon Ukrainy pro Vybory Narodnykh Deputativ Ukrainy (Law of Ukraine on the Election of Peoples Deputies of Ukraine)" no. 541/97, dated 24 September 1997 (VVR, 1997, No 43, art.280) <http://zakon.rada.gov.ua/cgi-bin/laws/main.cgi?nreg=541\%2F97\%E2\%F0>

Zakon Ukrainy pro Vybory Narodnykh Deputativ Ukrainy (Law of Ukraine on the Election of Peoples Deputies of Ukraine) no. 2766-III, dated 18 October 2001 (VVR, 2001, No51-52, art.265) <http://zakon1.rada.gov.ua/cgibin/laws/main.cgi?nreg=2766\%2D14\&p=1185383754148193>. 
Zakon Ukrainy pro Vybory Narodnykh Deputativ Ukrainy( Law of Ukraine on the Election of Peoples Deputies of Ukraine) no. 1665-IV, dated 25 March 2004 (VVR, 2004, No27-28, art.366) <http://zakon1.rada.gov.ua/cgi-bin/laws/main.cgi?nreg=1665$15>$.

Zakon Ukrainy pro Vnesennya Zmin do Zakony Ukrainy "Pro vybory narodnykh deputative Ukrainy."(Law of Ukraine on changes to the Law of Ukraine on the elections of Peoples Deputies of Ukraine) no. 2777-IV, dated 07 July 2005(VVR, 2005, No 38-39, art. 449) <http://zakon1.rada.gov.ua/cgi-bin/laws/main.cgi?nreg=2777-15>.

Verkhovna Rada Ukrainy. Postanova pro progoloshennya nezalezhnosti Ukrainy (Act of declaration of Ukraine independence) dated 24 August 1991 (VVR, 1991, No 38, art.502) $<$ http://zakon1.rada.gov.ua/cgibin/laws/main.cgi?nreg=1427\%2D12\&p=1172763330653063>.

Verkhovna Rada Ukrainy. Postanova pro stabilizatsiyu politychoyi ta socialnoeconomichnoyi sytuatsiy v Ukrainy ta zapobigannya antykonstytucyinym dyiam ta separatystskym proyavam shcho zagrozhuyut suverenitetu ta terytorialyniy cilisnosti Ukrainy (The resolution of the Verkhovna Rada on the stabilization of the political and socio-economical situation in Ukraine and prevention of the none constitutional and separatists actions that can threat to the state sovereignty of Ukraine) no. 2215-IVE, dated 01 December 2004(VVR, 2004, No50, art. 545) <http://zakon1.rada.gov.ua/cgibin/laws/main.cgi?nreg=2215-15>.

Verkhovna Rada Ukrainy. Proect Zakony pro parlamentcyku opozyciyul (Bill on the parliamentary opposition) dated 4 September 2006, 8 September 2006 <http://www.rada.gov.ua:8080/pls/zweb/webproc4_1?id=\&pf3511=27810>.

Verkhovna Rada Ukrainy. Ugoda pro Stvorennya Antykryzovoyi Koalitsii mizh Partiyeyu Regioniv, Sotsialistychnoyu Partiyeyu Ukrainy ta Komunistychnoyu Partiyeyu Ukrainy. (The agreement of the creation of anti-crisis coalition in the Verhkovna Rada of Ukraine between Party of Regions, Socialist Party of Ukraine and Communist Party of Ukraine) No 0005001-06, <http://zakon1.rada.gov.ua/cgi-bin/laws/main.cgi? nreg $=$ n0005001\%2D06\&p $=1175798876208401>$.

Verkhovna Rada Ukrainy. Ugoda pro Stvorennya Koalitsii Demokratychnykh Syl u Verkhovniy Rady (Agreement of the creation the coalition of the democratic forces in the Verkhovna Rada of Ukraine) <http://www2.pravda.com.ua/_site/html/Ugoda.doc>.

Presydent Ukrainy. Ukaz pro prypynennya povnovazhen Prem'yer-ministra Yuliyi Tymoshenko ta vidstavku Kabinetu Monistriv Ukrainy (Decree of the President of Ukraine on the Prime-Minister Yulia Tymoshenko and the dissolution of the Cabinet of Ministers of Ukraine) no.1234/2005, dated 08 September 2005, $<$ http://zakon1.rada.gov.ua/cgi-bin/laws/main.cgi?nreg=1234\%2F2005>. 


\section{Books}

Almond, Gabriel A., Verba, Sidney. The Civic Culture. Political Attitudes and Democratic Democracy in five nations. Boston: Little, Brown and Company, 1965.

Anders Åslund, Michael McFaul, eds. Revolution in Orange: the Origins of Ukraine's Democratic Breakthrough. Baltimore: Carnegie Endowment for International Peace, 2006.

Blondel, Jean. Political Parties. A genuine Case for Discontent? London: Wildwood House, 1978.

Birch, Sarah. Electoral Systems and Political Transformation in Post-Communist Europe. New York: Palgrave Macmilllan, 2003.

Birch, Sarah, Millard Frances, Popescu, Marina, Williams, Kieran, ed. Embodying Democracy, Electoral System Design in Post-Communist Europe. New York: Palgrave Macmillan, 2002.

Brown, Archie, Gray, Jack, ed. Political Culture and Political Change in Communist states. London: The Macmillan Press Ltd., 1977.

Crockett, David, A. The Opposition Presidency, Leadership and the Constraints of History. College Station: Texas A\&M University Press, 2002.

Dahl, Robert, A., ed. Political Opposition in Western Democracies. New Haven: Yale University Press, 1966.

---. Polyarchy, Participation and Opposition. New Haven: Yale University Press, 1971.

---, ed. Regimes and Opposition. New Haven: Yale University Press, 1973.

Detlef Pollack, Jan Wielgohs, eds. Dissent and Opposition in communist Eastern Europe: Origins of Civil society and Democratic transition. Burlington: Ashgate, 2004.

Diamond, Larry, Plattner, Marc F. Consolidating the Third Wave Democracies. Themes and Perspective. Baltimore: The Johns Hopkins University Press, 1997.

Duverger, Maurice. Political Parties. Their Organization and Activity in the Modern state. London: Methuem \& Co Ltd., 1964.

Elgie, Robert, ed. Semi-presidentialism in Europe. New York: Oxford University press, 1999. 
Greenberg, Douglas, Katz, Stanley, N., Oliviero, Malanie Beth, Wheatley, Steven, C. Constitutionalism and Democracy, Transitions in the Contemporary World. New York: Oxford University Press, 1993.

Grofman, Bernard and Lijphard, Arend. Electoral Laws and Their Political Consequences. New York: Agathon Press, Inc., 1986.

Gunter, Richard, Montero, Jose Ramon, Linz, Juan j., ed. Political Parties. Old Concepts and New Challenges. New York: Oxford University Press, 2002.

Harpham, Edward J., ed. John Locke's Two Treatises of Government. Lawrence, Kan: University Press of Kansas, 1992.

Hofstadter, Richard. The idea of a Party system. The rise of Legitimate Opposition in the Unites States, 1780-1840. Berkeley: University of California Press, 1969.

Hutchins, Robert, Maynard, ed. Great Books of the Western World, The works of Aristotle. Vol. II. Chicago: Encyclopedia Britannica, Inc., 1952.

Ionescu, Ghita, de Madariaga, Isabel. Opposition, Past and present of a Political Institution. London: C.A.Watts\&Co.Ltd., 1968.

Kitschelt Herbert, Mansfeldova Zdenka, Markowski Radoslaw, Toka Gabor. Postcommunist Party Systems. Cambridge: Cambridge University Press, 1999.

Kolinsly, Eva, ed. Opposition in Western Europe. London: Croom Helm Ltd, 1987.

Lane,Jan-Erik, Ersson Svante, ed. Culture and Politics: a comparative approach. Aldershot: Ashgate, 2002.

LeDuc, Lawrence, Niemi Richard G., Norris Pippa, ed. Comparing Democracies 2, New Challenges in the study of Elections and Voting. London: Sage Publications, 2004.

Linz, Juan, J., Valenzuela Arturo. The Failure of Presidential Democracy. Baltimore: The Johns Hopkins University Press, 1994.

Linz, Juan, J., Stepan, Alfred. Problems of Democratic transition and Consolidation. Southern Europe, South America, and Post-Communist Europe. Baltimore: The John Hopkins University Press, 1996.

Lijphard, Arend. Electoral Systems and Party Systems, A Study of Twenty-seven democracies. New York: Oxford University Press, 1994.

--- Pattern of Democracy, Governments Forms and Performance in thirty-six countries. New Haven: Yale University Press, 1999. 
Linonchuk S.G., Yarosh O.A. Парламентська опозиція в Україні: модель та провадження: Дослідження проблеми. Куіv:: Українский незалежний центр політичних досліджень, 2006.

Lipset, Seymour Martin, Lakin, Jason, M. The Democratic century. Norman: University of Oklahoma Press, 2004.

Locke, John. The second Treatise of Government, An essay Concerning the True Original, Extent and End of Civil Government. Oxford: Basil Blackwell, 1966.

McLennan, Barbara N., ed. Political Opposition and Dissent. New York: Dunellen Publishing Company, Inc., 1973.

Mair Peter. Party System Change, Approaches and Interpretations. New York: Oxford University Press, 1997.

Mettenheim, Kurt Von, ed. Presidential Institutions and Democratic Politics. Comparating Regional and National Contexts. Baltimore: The Johns Hopkins University Press, 1997.

Miller Arthur, H, Reisinger, William, M., Hesli, Vicki L, ed. Public Opinion and Regime Change. The New politics of Post-soviet Societies. Boulder: Westview Press, 1993.

Montesquieu. The Spirit of laws. Part Two, Book XI. Berkeley: University of California Press, 1977.

Olson, David, M. Democratic legislature institutions. A comparative View. New York: M.E. Sharpe Inc., 1994.

Panina, Natalya, ed. Ukrainian Society 1994-2004: Sociological Monitoring. Kyiv: Institute of Sociology, National Academy of Sciences of Ukraine, Democratic Initiatives Foundation. Available at $<$ :http://dif.org.ua/modules/pages/files/us\%2094-04e.pdf >.

Rae, Douglas W. The Political Consequences of Electoral Laws. New Haven: Yale University Press, 1971.

Reynolds, Andrew, ed. The architecture of Democracy: Constitutional Design, Conflict Management, and Democracy. New York: Oxford University Press, 2002.

Rosenbaum, Walter. Political Culture. New York: Praeger Publishers, 1975.

Sartori Giovanni. Parties and Party systems: A Framework for Analysis. London: Cambridge University Press, 1976. 
Schedler, Andreas, Diamond, Larry, Plattner, Marc F. The Self-restraining State. Power and Accountability in New Democracies. Bouler, Colorado: Lynne Rienner Publisher, Inc., 1999.

Shapiro, Leonard, ed. Political Opposition in One-party States. London: The Macmillan Press Ltd, 1972.

Skilling, Gordon, Griffiths, Franklyn, ed. Interest Groups in Soviet Politics. Princeton, New Jersey: Princeton University press, 1971.

Stepan, Alfred. Arguing Comparative Politics. New York: Oxford University Press, 2001.

Shugart, Matthew Soberg, Wattenberg Martin P. Mixed-Member Electoral Systems. The Best of Both Worlds? New York: Oxford University Press, 2001.

Shugart, Matthew Soberg, Taagepera, Rein. Seats and Votes. The effects and Determinants of Electoral Systems. New Haven: Yale University Press, 1989.

Welch, Stephen. The Concept of Political Culture. London: The Macmillan Press Ltd., 1993.

Wilson, Andrew. Ukraine's Orange Revolution. New Haven: Yale University Press, 2005.

White, Stephen. Political Culture and Soviet Politics. London: The Macmillan Press Ltd., 1979.

Wolczuk, Kataryna. The Moulding of Ukraine: the Constitutional Politics and State Formation. Budapest, Hungary: Central European University Press, 2001.

World almanac. New York: Newspaper enterprise association, Inc., 1982.

\section{Journals}

Birch, Sarah. “The Ukrainian Parliamentary and Presidential Election of 1994." Electoral Studies 14.1 (1995): 93-99.

Carey, John, Reynolds, Andrew. "Parties and Accountable Government in New Democracies." Party Politics 13.2 (2007): 255-274.

Christensen, Robert, K., Rakhimkulov, Edward, R., Wise, Charles, R. "The Ukrainian Orange Revolution brought more than a new president; what kind of democracy will the institutional changes bring?" Communist and Post-Communist Studies 38 (2005): 207230. 
Clark, Terry D., Wittrock, Jill,N. "Presidentialism and the Effect of Electoral Law in Postcommunist systems: Regimes Type Matters." Comparative Political Studies 38.2 (2005): 171-188.

D'Anieri, Paul. "Explaining the Success and Failure of Post-communist Revolutions." Communist and Post-Communist Studies 39 (2006): 331-350.

Duverger, Maurice. "A new political system model: semi-presidential Government." European Journal of Political Research 1.8 (June 1980): 165-187.

Ekiert, Crzegorz. "Democratization Process in East Central Europe: a theoretical reconsideration." British Journal of Political Science 21.3 (1991): 285-313.

Gallagher Michael. "Proportionality, Disproportionality and Electoral Systems." Electoral Studies 10.1 (1991): 33-51.

Grzymala-Busse, Anna. "Authoritarian Determinants of Democratic Party Competition: The Communist Successor Parties in East Central Europe." Party Politics 12.3 (2006): 415-437.

Hadenius, Axel, Teorell, Jan. "Pathways from authoritarianism." Journal of Democracy 18.1 (2007): 143-156.

Hale, Henry E. "Democracy or Autocracy on the march? The Colored revolution as Normal Dynamics of Patronal Presidentialism." Communist and Post-Communist Studies, 39 (2006): 305-329.

Harasymiw, Bohdan. "Elections in Post-Communist Ukraine, 1994-2004: Overview." Canadian Slavonic Papers XLVII.3-4 (2005): 191-240.

Helsi, Vicki L. "The Orange revolution: 2004 presidential election(s) in Ukraine." Electoral Studies 25 (2006): 147-191.

Kitschelt, Herbert. "Formation of Party Cleavages in Post-Communist Democracies: Theoretical Propositions." Party Politics 1.4 (1995): 447-472.

Kuzio Taras. "Civil society, Youth and Societal Mobilization in Democratic Revolutions." Communist and Post-Communist studies 39.3 (2006): 365-386.

Kuzio, Taras. "Oligarchs, Tapes and Oranges: 'Kuchmagate' to the Orange Revolution." Journal of Communist Studies and Transition Politics 23.1 (2007): 30-56.

Kuzio, Taras. "Yushchenko: Constructing an Opposition." Transitions online 11 Aug. 2006.

<http://www.tol.cz.proxy.library.carleton.ca/look/TOL/printf.tpl?IdLanguage>. 
Lijphart, Arend. "Constitutional design fro divided societies." Journal of Democracy 15.2 (2004): 96-109.

Ludger, Helms. "Five ways of Institutionalizing political opposition: lessons from the Advanced Democracies." Government and Opposition 39.1 (2004): 22-54.

Miller, Arthur, H., Hesli, Vicki L.,Reisinger, William., M. "Conceptions of Democracy among Mass and Elite in Post-Soviet Societies." British Journal of Political Studies 27.2 (1997): $157-190$.

Mishler, William, Rose Richard. "What are the Origins of Political Trust?: Testing Institutional and Cultural Theories in Post-communist Societies." Comparative Political Studies 34.1(2001):30-62.

Moser, Robert G., Scheiner, Ethan. "Mixed electoral systems and electoral system effects: controlled comparison and cross-national analysis." Electoral Studies 23 (2004): 575-599.

Poulard, Jean,V. "The French Double Executive and Experience of Cohabitation." Political Science Quarterly 105.2 (1990): 243-267.

Protsyk, Oleg. "Intra-executive Competition between President and Prime-minister: Patterns of Institutional Conflict and Cooperation under Semi-Presidentialism." Political Studies 54.2 (2006): 219-244.

Riabchuk, Mykola. "Learning democracy: The Internal Political Development of Ukraine since 1991." The Ukrainian Quarterly LXII.2 (2006): 217-221.

Siaroff, Alan. "Comparative presidencies: The inadequacy of the presidential, semipresidential and parliamentary distinction." European Journal of Political Research, 42 (2003): 287-312.

Stepan, Alfred. "Democratic Opposition and Democratization Theory." Government and Opposition 32.4 (1997): 657-675.

Thames, Frank, C. "Discipline and Party Institutionalization in Post- Soviet Legislature." Party Politics 13.4 (2007): 456-477.

Way, Lucan, A. "Individualism and political competition in Ukraine, 1992-2004." Communist and Post-Communist Studies 38.2 (2005):191-205.

Whitmore, Sarah. "Faction institutionalization and parliamentary development in Ukraine." Journal of Communist Studies and Transition Politics 19.4 (2003): 41-64. 


\section{Newspapers}

Editorial, "Ukraine's clear choice." The Globe and Mail 30 Oct. 2004: A20.

Maksymiuk Jan. "Ukraine: President Sacks Government, Offering More Questions than Answers", Radio Free Europe 09 September 2005 <http://www.rferl.org/featuresarticle/2005/9/776BA804-5279-4420-A2F8B7B3FF8F8A0A.html>.

Meek, James. "The millionaire revolutionary," The Guardian 26 Nov. 2004 <http://www.guardian.co.uk/g2/story/0,3604,1359986,00.html\#article_continue>.

Ukrayinska Pravda, November 21, 2004

<http://www.pravda.com.ua/news/2004/11/21/13935.htm>.

Orovezkiy Kirilo. "The political animal Moros." Ukrayinska Pravda 07 July 2006

<http://www.pravda.com.ua/news/2006/7/7/44076.htm>.

Andreychenko, Vita. "Oleksandr Moroz: from a mechanic-communist to the ally of Yanukovich.” Ukrayinska Pravda 07 July 2006

<http://www.pravda.com.ua/news/2006/7/7/44055.htm>.

Paraskevas, Joe. "Witness birth of new Ukraine." National Post 22 Dec. 2004, natl. ed.: A12.

Rakhmanin, Serhii. “Total Discord.” Serkalo nedeli 9-15 Dec. 2006

<http://www.zn.ua/1000/1030/55341/>.

Rakhmanin,Serhii, Mostovaya, Yulia. "Ukrainian political parties. Part III. Bloc Yulia Tymoshenko." Mirror Weekly 23 February- March 2002

<http://www.mw.ua/1000/1550/33937/>.

Rakhmanin, Serhii, Mostovaya, Yulia. "Ukrainian political parties. Part II. Bloc Our Ukraine.” Mirror Weekly No 6, February 2002

$<$ http://www.mw.ua/1000/1550/33858/>.

\section{Internet sources}

Central Electoral Commission of Ukraine

$<\mathrm{http}$ ://www.cvk.gov.ua/pls/vd2002/webproc0v>.

Democratic Initiative Foundation

$<$ http://www.dif.org.ua/ua/archive.vis\%20\%20\%20\%20\%20Democratic>.

Freedom House

$<$ http://www.freedomhouse.org/template.cfm?page=47\&nit=409\&year=2006>. 
Institute of Sociology, National Academy of Sciences of Ukraine

$<$ http://www.i-soc.com.ua/rus/index1.html>.

Official site of the Cabinet of Ministers of Ukraine

<http://www.kmu.gov.ua/control/uk/publish/article?\&art_id=1266975\&cat_id=661266>.

Official site of Party "Peoples Union Our Ukraine"

$<$ http://www.razom.org.ua/en/static/nsnu/>.

Official site of the Socialist Party of Ukraine <http://www.spu.in.ua/ua/dovidka/6558,>.

Official site of the Verkhovna Rada of Ukraine <http://zakon.rada.gov.ua/>.

Organization for Security and Co-operation in Europe

$<$ http://www.osce.org/documents/odihr/2005/05/14224 en.pdf $>$.

Radio Free Europe

$<$ http://www.rferl.org/featuresarticleprint/2006/01/e914e4d3-3b0a-4de9-84bc-

9 cad6b778f2c.html $>$.

State Statistics Committee of Ukraine <http://www.ukrstat.gov.ua/>.

Viktor Yushchenko, Home Page <http://www.yuschenko.com.ua/ukr/Future/206/>.

Yulia Tymoshenko, Home Page <http://www.tymoshenko.com.ua/ukr/about/>.

Ukrainian Census 2001 <http://www.ukrcensus.gov.ua/eng/results/general/age/>.

World Bank

<http://siteresources.worldbank.org/UKRAINEEXTN/Resources/Macro_update_eng.pdf $>$.

World Value Survey, countries reports

$<$ http://www.jdsurvey.net/bdasepjds/QuestionCrosstab.jsp>. 